\title{
PROPAGAÇÃO VIA ESTACAS APICAIS, CARACTERIZAÇÃO MORFOLÓGICA E MOLECULAR DE JABUTICABEIRAS (Myrciaria spp)
}

\section{MÁRCIO PEREIRA}

Tese apresentada à Escola Superior de Agricultura "Luiz de Queiroz", Universidade de São Paulo, para obtenção do título de Doutor em Recursos Florestais, com opção em Silvicultura e Manejo Florestal.

PIRACICABA

Estado de São Paulo - Brasil

Outubro - 2003 


\title{
PROPAGAÇÃO VIA ESTACAS APICAIS, CARACTERIZAÇÃO MORFOLÓGICA E MOLECULAR DE JABUTICABEIRAS (Myrciaria spp)
}

\author{
MÁRCIO PEREIRA
}

Biólogo

Orientador: Prof. Dr. ANTONIO NATAL GONÇALVES

Tese apresentada à Escola Superior de Agricultura "Luiz de Queiroz", Universidade de São Paulo, para obtenção do título de Doutor em Recursos Florestais, com opção em Silvicultura e Manejo Florestal.

PIRACICABA

Estado de São Paulo - Brasil

Outubro - 2003 
Dados Internacionais de Catalogação na Publicação (CIP) DIVISÃO DE BIBLIOTECA E DOCUMENTAÇÃO - ESALQ/USP

Pereira, Márcio

Propagação via estacasapicais, caracterização morfológica e molecular de jabuticabeiras (Myrcia ria spp) / Márcio Pereira. - -

Pira cic aba, 2003.

86 p. : il.

Tese (doutorado) - Escola Superior de Agricultura Luiz de Queiroz, 2003.

Bibliografia.

1. Estacas (plantas) 2. Genétic a molecular vegetal 3. J abuticaba 4. Morfo-logia vegetal 5. Mudas 6. Propagação vegetal 7. Variação genética vegetal I. Título

CDD 634.42

"Permitida a cópia total ou parcial deste documento, desde que citada a fonte - O autor" 
À minha querida esposa Regina,

Pelo companheirismo, pela compreensão,

E por todos os momentos que passamos juntos.

Dedico.

Aos meus filhos, David e Joara, pelo carinho, dedicação durante toda essa jornada.

Ofereço. 


\section{AGRADECIMENTOS}

Aos professores, Antonio Natal Gonçalves e Marcílio de Almeida, pela orientação, dedicação e amizade.

A Escola Superior de Agricultura "Luiz de Queiroz", Universidade de São Paulo, pela possibilidade de realização do curso.

Ao Departamento de Ciências Florestais e aos professores do curso de pósgraduação, pelos ensinamentos recebidos.

Aos companheiros da FAFRAM , Prof. Paulo César Corsini, Prof. Antonio Luis de Oliveira, e Profa. Regina Eli de Almeida Pereira, pelo incentivo e colaboração na execução deste trabalho.

A Fundação Educacional de Ituverava, em nome do seu presidente e vicepresidente, Sr. Cesar Luiz Mendonça e Carlos Fernando Rossato, pelo apoio e confiança depositada.

Ao Engenheiro Florestal, Percy Zevalos Pólito, pelo companheirismo e colaboração.

Aos curadores dos herbários do IAC, Unicamp, USP-São Paulo, Instituto de Botânica, IF, UFU, e UFMG.

Ao colega, Osny do IF, pela colaboração na identificação de campo.

A Profa. Janete Desidério e a mestranda Juliana do Departamento de Biologia Aplicada da UNESP-Jaboticabal, pelo grande auxílio na análise molecular.

A bibliotecária, Eliana Maria Garcia e Silvia, pela revisão do texto.

Ao grande arquiteto do Universo que sempre iluminou meu caminho. 


\section{SUMÁRIO}

Página

LISTA DE FIGURAS .................................................................. vii

LISTA DE TABELAS..................................................................... viii

RESUMO ........................................................................... ix

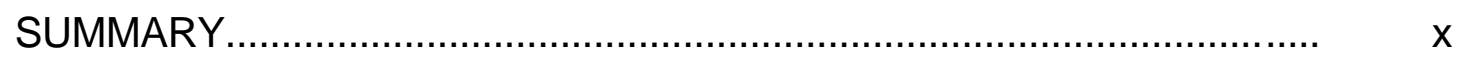

1 INTRODUÇÃO ..................................................................... 1

2 REVISÃO DE LITERATURA ..................................................... 3

1.1 Generalidades .................................................................... 3

1.2 Produção de mudas através de estacas.......................................... 5

1.3 Fatores que influem na indução de enraizamento nas estacas .......... 6

1.3.1 Água, temperatura e substrato .................................................. 10

1.4 Uso de reguladores vegetais como promotores de enraizamento ...... 11

1.5 Anatomia e fisiologia do enraizamento ............................................ 14

1.6 Técnicas de uso corrente na avaliação da diversidade genética ....... 19

3 INFLUÊNCIA DE SUBSTRATOS, VALORES DE PH, CONCENTRAÇÕES DE AIB NA PROPAGAÇÃO DA JABUTICABEIRA (Myrciaria jabuticaba (Vell) O. Berg.) ATRAVÉS DE ESTACAS APICAIS ............................... 22

3.1 Introdução ................................................................................. 22

3.2 Material e Métodos ...................................................................... 25

3.3 Resultado e Discussão ............................................................ 32 
4 CARACTERIZAÇÃO MORFOLÓGICA E MOLECULAR DE ESPÉCIES DE JABUTICABEIRA (Myrciaria spp) ………………….................. 45

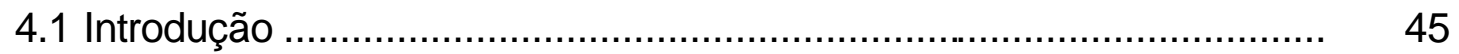

4.2 Material e Métodos .......................................................................... 48

4.2.1 Análise Morfológica .............................................................. 48

4.2.2 Coleta do Material para Identificação Botânica ............................... 49

4.2.3 Revisão de Herbários .................................................................. 52

4.2.4 Caracterização Molecular ........................................................... 53

4.2.5 Extração de DNA de tecido vegetal .............................................. 54

4.3 Reagentes ............................................................................. 55

4.3.1 Quantificação e verificação da qualidade do DNA genômico .......... 55

4.3.2 Amplificação do DNA por PCR .................................................. 56

4.3.3 Análise estatística ..................................................................... 58

4.4 Resultados e Discussão ............................................................ 59

4.4.1 Caracterização Morfológica ..................................................... 59

4.4.2 Identificação morfológica .............................................................. 66

4.4.3 Caracterização Anatômica ............................................................. 68

4.4.4 Caracterização Molecular .......................................................... 73

4.5 Conclusões ............................................................................ 78

5 CONCLUSÕES GERAIS ............................................................ 79

REFERÊNCIAS BIBLIOGRÁFICAS ................................................. 80 


\section{LISTA DE FIGURAS}

Página

1 Diagrama da raiz em crescimento primário (adaptado de Taiz \& Zei ger, 1998)

2 Modelo de Desenvolvimento de raiz em estacas (AFTER CELENZA et al., 1995, adaptado por TAIZ \& ZEIGER, 1998)

3 Raízes laterais originadas da diferenciação do periciclo em Arabido psis (DOLAN et al., 1993, adaptado por TAIZ \& ZAIGER, 1998)

4 Vista das árvores matrizes de jabuticabeiras dos quais foram coleta das as estacas apicais

5 Dados diários das temperaturas máximas, médias e mínimas, do mês de abril de 2002. Dados coletados no Posto Agrometeorológico do Departamento de Ciências Exatas - ESALQ - USP

6 Estacas apicais de jabuticabeiras sendo coletadas e preparadas pa ra receberem a pasta auxínica

7 Vista dos estufins abertos para serem pulverizados com soluções de $\mathrm{pH}$ correspondente ao do substrato

8 Vista geral dos estufins

9 Dados diários, expressos em médias quinzenais, das temperatu ras máximas, médias e mínimas, durante a condução do experimento na Faculdade de Agronomia de Ituverava (Fafram) * Dados obtidos do Departamento de Engenharia Rural

10 Dados diários, expressos em médias quinzenais, das temperaturas máxima, média e mínima no interior do estufim 
11 Interação dos diferentes valores de $\mathrm{pH}$ e dos substratos (areia grossa e vermiculita) na porcentagem de enraizamento de estacas apicais de jabuticabeira 'Sabará'

12 Interação dos diferentes valores de $\mathrm{pH}$ e do substrato areia grossa na porcentagem de enraizamento de estacas apicais de Jabuticabei ra 'Sabará'

13 Interação dos diferentes valores de $\mathrm{pH}$ e do substrato vermiculita na porcentagem de enraizamento de estacas apicais de Jabuticabei ra 'Sabará'

14 Estacas apicais de Jabuticabeira com 0mg. $\mathrm{L}^{-1}$ de AIB, no substra to areia grossa e pH 3.5 aos 180 dias, com formação calos e sem formação de raízes adventícias

15 Estacas apicais de Jabuticabeira com $0 \mathrm{mg}^{-\mathrm{L}^{-1}}$ de AIB, no substra to vermiculita e pH 3.5 aos 180 dias, apresentando formação de calos na região basal

16 Estaca apical de Jabuticabeira com $4000 \mathrm{mg} \cdot \mathrm{L}^{-1}$ de AIB, no substra to vermiculita e $\mathrm{pH} 4.5$ aos 180 dias, apresentando a formação de uma vigorosa raiz adventícia e de uma brotação vegetativa lateral .......

17 Estacas apicais de Jabuticabeira com $4000 \mathrm{mg} \cdot \mathrm{L}^{-1}$ de AIB, no substrato areia grossa e pH 4.5 aos 180 dias, mostrando a forma ção da raiz adventícia

18 Estaca apical de Jabuticabeira com $2000 \mathrm{mg} \cdot \mathrm{L}^{-1}$ de AIB, no substra to areia grossa e pH 4.5 aos 180 dias, mostrando a formação de raí zes adventícias na base da estaca

19 Estacas apicais de com $2000 \mathrm{mg} \cdot \mathrm{L}^{-1}$ de AIB, no substrato vermicu lita e $\mathrm{pH} 4.5$ aos 180 dias

20 Estacas apicais de Jabuticabeira com $4000 \mathrm{mg} \cdot \mathrm{L}^{-1}$ de AIB, no substrato vermiculita e pH 5.5 aos 180 dias, mostrando raí zes adventícias vigorosas

21 (a) Prensa, (b) Exsicata

22 Myrciaria jaboticaba - (a) detalhe da flor; (b) ramos com fru tos maduros 
24 Myrciaria phitrantha Mattos - Ramos terminais com folhas grandes e pendentes e detalhe dos frutos

25 Corte transversal da região de um ramo terminal de Myrciaria phitrantha, apresentado suber (sb) pluriestratificado com uma cama da espessa de periderme (pd)

26 Corte transversal da região da casca do caule de Myrciaria coronata Mattos mostrando a presença de fibras floemáticas (ff) formando ex tratos contínuos, suber uniestratificado (sb). Raio parenquimático (rp) com uma única camada de células e células de xilema secundário (xs) não alinhadas

27 Corte transversal do ramo terminal, região da casca, de Myrciaria cauliflora (DC.) Berg, mostrando fibras floemáticas (ff) formando extratos contínuos. Células do raio parenquimático (rp) atravessa ndo a região do floema. Células de periderme (pd) formando uma camada pouca espessa e um suber uniestratificado

28 Corte transversal do ramo terminal, região da casca, de Myrciaria jaboticaba (Vell.) Berg, mostrando fibras floemáticas (ff) formando extratos contínuos. Células de periderme (pd) formando uma cama da pouca espessa e um suber uniestratificado. Raios parenquimá ticos pouco visíveis

29 Corte transversal do caule de Myrciaria phitrantha, região do lenho, mostrando células do raio parenquimático (rp) com uma única camada de células de elemento de vaso de maior diâmetro (ev) dispostas de uma maneira alinhada, sendo envolvidas por células parenquimáticas de comunicação entre os raios (cpc)

30 Corte transversal do caule de Myrciaria coronataMattos, mostrando a região do lenho com as células do raio parenquimático (rp) com uma única camada e células de xilema secundário (ev) dispostos de uma maneira não alinhada, e não envolvidas por células do raio ......

31 Corte transversal do caule de Myrciaria jaboticaba (Vell.) O. Berg, da região do lenho, mostrando raios parenquimáticos (rp) mais lar gos com células de elemento de vaso (ev) xilema dispostas de uma maneira não alinhada 
32 Corte transversal do caule de Myrciaria cauliflora (DC.) Berg., regi ão do lenho, mostrando as células do raio parenquimático (rp) com duas camadas e células do xilema secundário (ev) não alinhadas e não envolvidas por células do raio

33 Eletroforograma dos acessos amplificados com indicador de núme ro 203, sendo: $\mathrm{MM}=" 1 \mathrm{~Kb}$ Plus DNA Ladder"

34 Eletroforograma dos acessos amplificados com indicador de núme ro 226, sendo: $\mathrm{MM}=" 1 \mathrm{~Kb}$ Plus DNA Ladder"

35 Filograma de similaridade genética entre os indivíduos de jabuticabeiras, obtido pelo coeficiente de Jacard 


\section{LISTA DE TABELAS}

\section{Página}

1 Efeito do substrato, valores de pH e concentrações de AIB no enraiza mento e sobrevivência de estacas apicais de jabuticabeiras (Myrci aria spp) 'Sabará'

2 Efeito da interação dos diferentes valores de $\mathrm{pH}$ e dos substratos na porcentagem de enraizamento de estacas apicais de jabutica beiras 'Sabará'

3 Herbários usados para revisão do material botânico

4 Seqüências arbitrárias dos iniciadores utilizados e respectivos núme ros de acessos

5 Relação das espécies do gênero Myrciaria encontradas nos herbários visitados

6 Relação das espécies de jabuticabeiras identificadas, através da comparação de exsicatas presentes nos herbários visitados e na consulta de bibliografia especializada 


\title{
PROPAGAÇÃO VIA ESTACAS APICAIS, CARACTERIZAÇẨO MORFOLÓGICA E MOLECULAR DE JABUTICABEIRAS (Myrciaria spp)
}

\author{
Autor: MÁRCIO PEREIRA \\ Orientador: Prof. Dr. ANTONIO NATAL GONÇALVES
}

\section{RESUMO}

Com o objetivo de avaliar a influência de diferentes tipos de substratos, valores de pH e concentrações de AIB (Ácido Indolbutírico) no enraizamento de estacas apicais de jabuticabeiras (Myrciaria jaboticaba (Vell.) O. Berg), e caracterizar morfológica e molecularmente espécies de jabuticabeiras, foram realizados dois experimentos. No primeiro, foram coletadas estacas apicais de matrizes de jabuticabeiras da espécie Myrciaria jaboticaba (Vell.) O. Berg, e submetidas à condições de enraizamento. O delineamento adotado foi o de subparcelas subsubdivididas $2 \times 4 \times 5$, onde os substratos areia grossa e vermiculita constituíram as subparcelas ou unidades inteiras, os pHs $(3.5 ; 4.5 ; 5.5$ e 6,5) constituíram os quatro valores, e as concentrações de AIB $(0 ; 1000 ; 2000 ; 4000$ e $6000 \mathrm{mg} . \mathrm{L}^{-1}$ ) as subsubparcelas. O substrato areia grossa, quando interagiu com os pHs 4.5 e 5.5 proporcionou uma maior taxa de enraizamento nas estacas apicais de jabuticabeiras, já pHs elevados (6.5) e baixos (3.5), para os dois substratos, inibiram a emissão de raízes na base das estacas. As diferentes concentrações de AIB não influenciaram no enraizamento das estacas apicais. No segundo experimento, foram caracterizadas plantas de jabuticabeiras dos pomares do Setor de Horticultura do Departamento de Produção Vegetal da ESALQ-USP-Piracicaba-SP e do pomar de fruticultura da FAFRAM (Faculdade "Dr. Francisco Maeda" de Ituverava-SP). Para a caracterização cas espécies, foram comparadas as características anatômicas do caule, características morfológicas através da comparação com os espécimes de herbários, revisão de literatura especializada e análise molecular através do uso de marcadores (RAPDPCR). Foram identificados 4 grupos distintos, sendo que as espécies foram: Myrciaria phytrantha (Kiaersk.) Mattos, Myrciaria jaboticaba (Vell.) O. Berg, Myrciaria coronata Mattos, Myrciaria cauliflora (Mart.) O. Berg. A técnica de 
marcadores moleculares aliado ás técnicas de marcadores morfológicos (morfologia externa e interna), mostrou ser uma ferramenta importante na identificação de espécies de jaboticabeiras.

Palavras-chave: estacas apicais, propagação vegetativa, enraizamento, AIB, jabuticabeiras. 


\section{APICAL CUTTINGS PROPAGATION, MORPHOLOGIC AND MOLECULAR CHARACTERIZATION OF JABUTICABA TREES (Myrciaria spp)}

Author: MÁRCIO PEREIRA

Adviser: Prof. Dr. ANTONIO NATAL GONÇALVES

\section{SUMMARY}

Two experiments were conducted with de main objective to verify the influence of different types of substracts, $\mathrm{pH}$ levels and IBA concentrations on rooting of jabuticaba trees, cuttings (Myrciaria jaboticbal (Vell.) O. Berg) and characterize 4 jabuticaba trees' species using morphological and molecular tools. In the first experiment, jabuticaba trees' apical cuttings were collected and put on rooting condictions. The estatistic delineation used was split plot $(2 \times 4 \times 5)$, in which thick sand and vermiculite were considered subparcels or entire units, $\mathrm{pH}$ (3.5; $4.5 ; 5.5$ e 6.5$)$ were considered the four levels and IBA concentrations ( 0 ; 1000; 2000; 4000 e 6000 mg. $\mathrm{L}^{-1}$ ) were considered subsubparcels. The interaction between thick sand and 4.5 and $5.5 \mathrm{pH}$ levels provided the best rooting taxes for jabuticaba trees' apical cuttings, while 6.5 e $3.5 \mathrm{pH}$ levels, had inhibited the emission of roots. IBA different concentrations had not influenced the rooting of apical cuttings. The second research was carried on two orchards: one located in Horticulture Sector of Vegetal Production Departament from ESALQ-USP, Piracicaba, SP, and another from College "Dr. Francisco Maeda" (FAFRAM), Ituverava, SP. To the species characterization, stem anatomical and morphological characteristics were compared using herbarium search, specialized literature revision and molecular analysis by the use of biological markers (RAPDPCR). Four different groups were identified: Myrciaria phytrantha (Kiaersk) Mattos; Myrciaria jaboticaba (Vell.) O. Berg; Myrciaria coronata Mattos e Myrciaria cauliflora (Mart.) O. Berg. The molecular markers technique connected with morphological markers (external and internal morphology) showed to be an important tool used to identify jabuticaba tree species.

Key words: apical cuttings, propagation, jaboticaba tree. 


\section{INTRODUÇÃO}

A jabuticabeira é conhecida há quase cinco séculos. O seu nome é originário do tupi, "iapoti'kaba", o que significa "fruta em botão" (MENDONÇA, 2000).

A jabuticabeira é uma planta nativa do Brasil, sendo encontrada em extensa faixa do país, desde o Pará até o Rio Grande do Sul, entretanto, sua maior ocorrência e produtividade está nos estados da região sudeste. As frutas produzidas por esta espécie são muito apreciadas em todo o país, sendo consumida 'in natura', ou processada na forma de suco, geléia, licor e até mesmo na forma de vinho (MATOS, 1983 \& DONADIO, 2000).

Um dos problemas enfrentados para a expansão dos pomares comerciais é a obtenção de mudas. A maioria dos viveristas opta pela propagação através de sementes. Nesse caso, apesar da característica poliembriônica das sementes de jabuticabeira proporcionar a obtenção de plântulas de origem nucelar (51\% para o cultivar Sabará), que conservam a identidade da planta matriz (ANDERSEN \& ANDERSEN, 1988), a longa fase juvenil das plantas ainda persiste (14 anos aproximadamente). Para solucionar esse problema tem sido usado a propagação vegetativa ou agâmica, pois permite a manutenção das características da planta matriz nos descendentes, reduz ou elimina a fase juvenil e constitui-se em um método mais rápido e econômico (HARTMANN et al., 1990).

A propagação vegetativa, visando a redução da fase juvenil, tem sido pesquisada, porém, os resultados obtidos ainda não permitiram a definição de um método prático que confirme essa eficiência. Os métodos tradicionais de estaquia 
apresentam suas limitações, pois exigem que a estaca tenha diâmetro de 1,5-2,0 cm, com $40 \mathrm{~cm}$ de comprimento (JABUTICABA, 1990), acarretando grande dano à planta matriz. A multiplicação através de estacas apicais, apesar de ser uma técnica recente, vem sendo usada com sucesso para as culturas de eucalipto, goiaba, e outras frutíferas pertencentes à mesma família da jabuticabeira (Myrtaceae), que além de causar um menor dano às plantas matrizes também otimiza o uso das instalações dos viveiros (MENDONÇA, 2000).

Por ser considerada uma planta de "fundo de quintal", com denominações bastante variáveis, essas plantas apresentam ainda sérios problemas quanto à sua classificação taxonômica, existindo controvérsias quanto àdiferenciação entre as espécies, aliado ao grande número de nomes populares atribuído em cada região do país , o que prejudica sobremaneira a sua classificação, causando certa confusão. Muitas vezes, indivíduos do mesmo gênero até mesmo de mesma espécie recebem denominações diferentes (MATTOS, 1983).

$\mathrm{Na}$ tentativa de solucionar alguns problemas relacionados àpropagação e a identificação da jabuticabeira o presente trabalho tem o objetivo de avaliar a influência de diferentes tipos de substratos, valores de pHs, além de concentrações de AIB e suas respectivas interações na indução de primórdios radiculares em estacas apicais de jabuticabeiras, e também comparar a diversidade genética entre espécies de jabuticabeiras através do uso de marcadores moleculares (RAPD), e características morfológicas. 


\section{REVISÃO DE LITERATURA}

\subsection{Generalidades}

As "Jabuticabeiras" (Myrciaria spp.) são plantas muito conhecidas, em todo sul e sudeste do Brasil, devido aos deliciosos frutos que produzem. Cultivadas como plantas de fundo de quintal, em pomares domésticos de chácaras, sítios ou fazendas o seu fruto é muito apreciado para consumo "in natura", ou na forma de geléia, licores, vinhos. Das frutas típicas brasileiras, a jabuticaba é uma das mais populares. A jabuticabeira pode ser encontrada em todo o país, produzindo melhor nos Estados de São Paulo, Minas Gerais, Rio de Janeiro, Paraná e Goiás (OLIVEIRA, 2002).

As jabuticabeiras podem ser cultivadas na maior parte do território nacional. Encontram-se vegetando bem desde o Nordeste em lugares com temperaturas não elevadas, até o Noroeste do Planalto Médio, no Rio Grande do Sul (MATTOS, 1983).

A temperatura ideal média para a jabuticabeira varia entre $20^{\circ} \mathrm{C}$ a $25^{\circ} \mathrm{C}$, sendo que temperaturas muito baixas afetam a produtividade da jabuticabeira. Quanto a pluviosidade, o ideal está entre 1200 a 1500 mm/anual. No caso específico da jabuticabeira, há necessidade de chuva bem distribuída, pelo menos $100 \mathrm{~mm}$ mensais (MATTOS, 1983).

Os solos para as jabuticabeiras devem ser preferencialmente silicoargilosos, profundos, férteis bem dotados de umidade e permeáveis (MATTOS, 1983). 
A maior parte da produção de jabuticaba é comercializada na forma de fruto "in natura", sendo que a região metropolitana de São Paulo é o maior centro consumidor, com 84 gramas per capita anual, segundo pesquisa POF/IBGE87/88. Em 1990, no entreposto do Ceagesp - São Paulo, foram comercializadas 1,2 mil toneladas desse fruto. Desse total, 93,54\% (1159 t) é produzido no próprio estado de São Paulo, sendo o restante oriundo de outros Estados, e até mesmo dos Estados Unidos (SÃO PAULO, 1990).

A produção de jabuticaba apresenta uma sazonalidade bem definida, entretanto, a amplitude de variação dos índices de produção é bastante alta (455\%), indicando extrema instabilidade na oferta desse produto. Baseando-se apenas nos índices disponíveis de variação de quantidade de mercado, a maior produção ocorre nos meses de setembro e outubro (OLIVEIRA, 2002).

O valor nutritivo da jabuticabeira é pouco conhecido, aparentemente, os frutos apresentam boa quantidade de Niaciana e Ferro. Porém, a composição que são apresentadas nas tabelas atualmente utilizadas, não levam em consideração a espécie avaliada (KANESIRO, 2002).

Segundo a mesma autora, a quantidade de informações sobre a jabuticabeira ainda é muito pequena, principalmente no que se refere as suas potencialidades na indústria alimentícia. Os produtos como compotas, licores, sucos, geléias, vinho são produzidos de maneira praticamente artesanal, em pequena escala. Algumas empresas de maior porte apresentam interesse nesta fruta, porém esbarram na falta de matéria-prima uniforme e na ausência de informações sobre o processamento industrial.

São escassas as informações sobre pomares comerciais no estado de São Paulo, sendo que os principais municípios produtores da fruta para consumo in natura são: Casa Branca, Descalvado e Jaboticabal. Pomares esses implantados em meados do século passado. Os pomares mais antigos e inclusive alguns recém implantados foram formados com mudas produzidas a partir de sementes, 
porém, alguns produtores ao reporem árvores mortas já estão preocupados com o longo período juvenil dessas mudas.

Segundo Manica (2000), o uso de mudas enxertadas, apesar de reduzir o período juvenil, ainda é pouco utilizada pelo produtor em decorrência do alto custo e pela sua baixa produção, tornando-se mais apropriadas as mudas produzidas através da estaquia.

\subsection{Produção de mudas através de estacas}

A propagação vegetativa ou assexual é utilizada para produzir uma planta genotipicamente idêntica à planta-mãe, sendo a estaquia o método mais importante e utilizado para a produção de mudas de muitas espécies ornamentais e algumas frutíferas (DONADIO, 2000).

Segundo Vilanova (1959), a propagação vegetativa ou assexual tem sido definida como: "a produção de plantas, empregando partes vegetativas como caules, raízes e folhas. No lugar de usar sementes". Esse processo só é possível devido à capacidade que certos órgãos vegetais possuem de se recomporem, quando cortados e colocados em condições favoráveis, dando origem a um novo indivíduo com características idênticas às de seu genitor. Com relação ao seu emprego, a propagação vegetativa é largamente utilizada em floricultura, horticultura, fruticultura e silvicultura, com o objetivo de melhorar e conservar clones, ecótipos ou variedades de importância econômica (SILVA, 1985).

As estacas podem ser obtidas de porções vegetativas de caules, caules modificados (rizomas, tubérculos e bulbos), folhas ou raízes. Muitas espécies podem ser propagadas por um ou mais tipos de estacas, selecionando-se o tipo de acordo com a disponibilidade de material vegetativo e facilidade de sua obtenção. A estaca proveniente de caules tem a vantagem de sua fácil obtenção e maior disponibilidade de material, apresentando resultados satisfatórios. 


\subsection{Fatores que influem na indução de enraizamento nas estacas}

A propagação vegetativa, através de estaca caulinar, é possível pelo fato de algumas células conterem informações genéticas necessárias para induzir a diferenciação e em seguida formar uma planta toda. Essa propriedade é chamada de totipotência, ou seja, é a capacidade que algumas células tem de sofrer uma diferenciação quase que ilimitada, desde que as condições sejam satisfatórias para expressão gênica, Almeida ${ }^{1}$.

As estacas caulinares podem ser provenientes de ramos lenhosos arbóreos ou arbustivos, de caules semilenhosos e herbáceos. Essas estacas devem ser provenientes de ramos terminais de maturação recente, de plantas sadias e vigorosas, sendo o vigor e a sanidade especialmente importantes como fatores condicionantes da facilidade para o enraizamento das espécies. É recomendado ainda não usar plantas com deficiência em nutrientes ou atacadas por pragas e insetos e pulverizadas recentemente com óleo, devendo ser evitado o uso de plantas que tenham sido danificadas por geada ou seca e aquelas que se encontrem em plena floração ou frutificação (HARTMANN et al., 1990).

As estacas caulinares devem possuir, se possível, 2 folhas cortadas ao meio e no mínimo duas gemas, sendo o corte superior realizado acima de uma gema e o inferior logo abaixo de outra gema.

Na produção de mudas por estaquia, é importante entender o papel da diferenciação e desdiferenciação celular, pois será devido a esses dois fatores que a estaca emitirá as raízes.

Os fatores que controlam a diferenciação das células alvo, geneticamente iguais nos vários tecidos estão começando a ser compreendidos, mas é possível, æ̀s vezes, correlacionar a diferenciação de tecidos particulares com situações

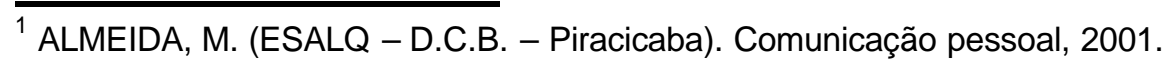


fisiológicas específicas nas células, embora uma conexão causal nem sempre tem sido demonstrada, Gonçalves².

Os primórdios radiculares que serão formados na base das estacas, oriundos da desdiferenciação e diferenciação das células alvo, apresentaram todos os tecidos e organizações de uma região de um segmento de raiz em crescimento primário (Figura 1).

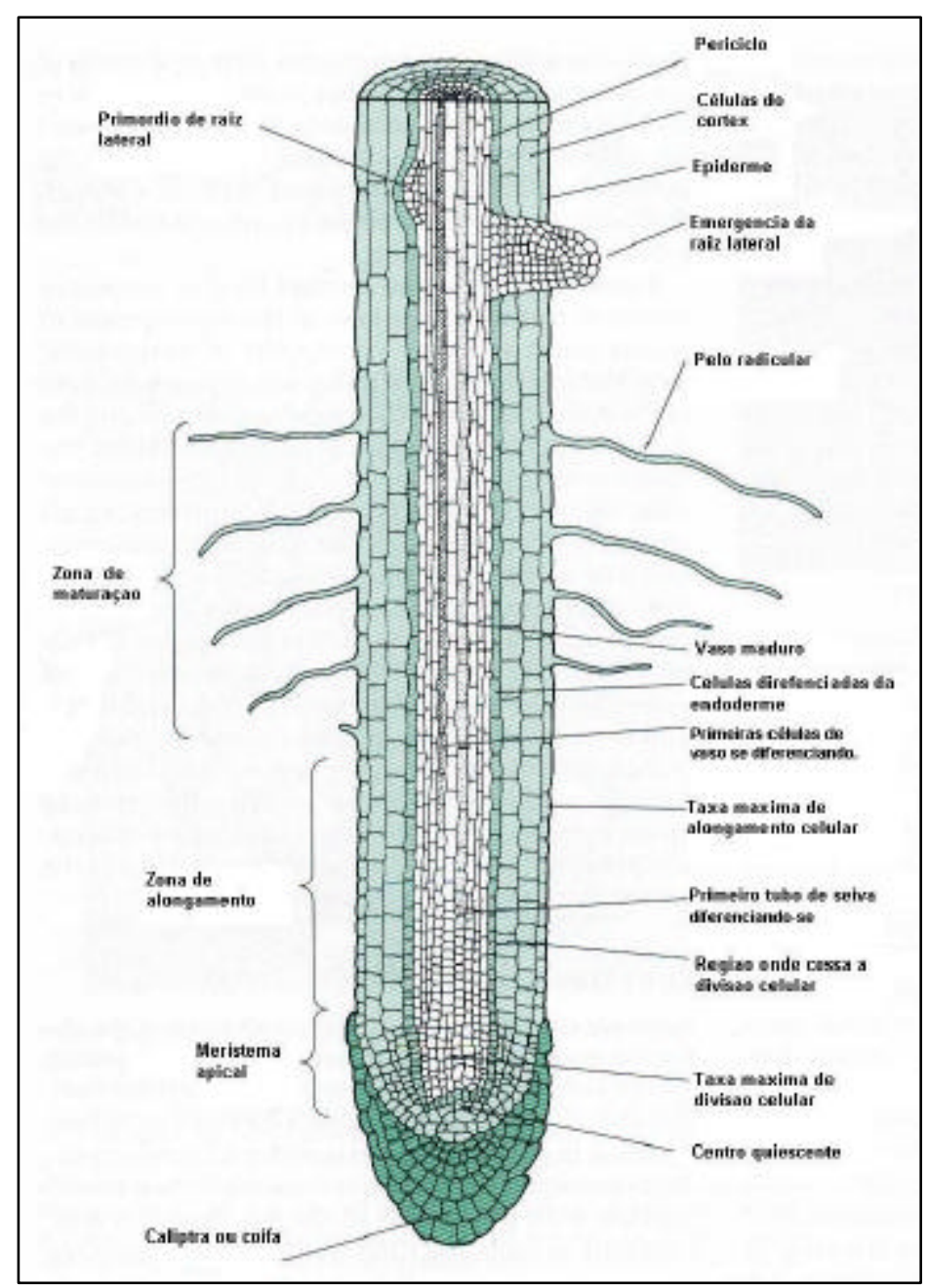

Figura 1 - Diagrama da raiz em crescimento primário (adaptado de Taiz \& Zeiger, 1998)

\footnotetext{
$\overline{2}$ GONÇALVES, A.N. (ESALQ - D.C.F. - Piracicaba). Comunicação pessoal, 2002.
} 
Na propagação vegetativa é importante relacionar a estação do ano com as fases de desenvolvimento das plantas e o enraizamento das estacas. A influência da estação do ano sobre o enraizamento de estacas, vem sendo estudado em várias plantas de interesse econômico. Essa variação na capacidade de enraizamento em função das estações do ano é atribuída às fases de crescimento da planta e ao estado bioquímico das estacas (HARTMANN et al., 1990).

MUÑOZ \& VALENZUELA (1978) relata grande enraizamento em estacas semilenhosas de Populus robusta, quando retiradas da planta matriz na fase de crescimento ativo, ou seja, na estação do verão as estacas lenhosas dormentes enraizaram melhor do que quando retiradas no outono. Em outros trabalhos com estacas de Vitis vinifera L., foi verificado que a porcentagem de enraizamento decrescia conforme se aproximava do outono. Os autores relacionaram esta diminuição às variações no conteúdo de co-fatores e/ou na formação e acúmulo de inibidores de enraizamento. O máximo de enraizamento nesse estudo foi obtido na metade do verão, coincidindo com o período de máxima atividade da planta.

Ainda, com relação ao período de retirada das estacas da planta-mãe, Evans (1958) trabalhando com estacas de Coffea arabica L., observou que estacas de ramos coletados durante a estação chuvosa no Quênia (junho) apresentaram maior porcentagem de enraizamento. Entretanto, verificou-se que nos meses de outubro e novembro a porcentagem de enraizamento foi alta, atribuindo esse aumento à elevada taxa de precipitação ocorrida nesses dois meses. Isso levou-o a concluir pela existência de relação entre a capacidade de enraizamento das estacas e a quantidade de chuva. ONO et al. (1992), trabalhando com estacas de café (Coffea arabica L. cv. Mundo Novo), também verificaram que a melhor época de coleta das estacas foi durante a época de altas precipitações, sendo os resultados incrementados pela aplicação de ANA $200 \mathrm{mg}$. $\mathrm{L}^{-1}$ mais boro $150 \mu \mathrm{g} / \mathrm{ml}$ na base das estacas. 
Middleton et al. (1980), relataram a existência de fatores endógenos, além das auxinas, que estimulam 0 enraizamento das estacas. Tais fatores, aparentemente, aparecem nas folhas e gemas, incluindo desde os carboidratos e compostos nitrogenados, até as várias substâncias sinérgicas da auxina.

De acordo com Van Overbeek et al. (1946), as folhas no enraizamento das estacas são consideradas como fonte de auxinas e nutrientes, necessárias para a formação de raízes nas estacas. Os autores trabalharam com estacas de Hibiscus rosa-sinensis L., com e sem folhas, verificando que estacas sem folhas e não tratadas com auxinas não mostraram formação de raízes, mas quando as folhas estavam presentes, mesmo sem tratamento auxínico, ocorreu formação de raízes, embora em pequena quantidade. Entretanto, quando estacas possuíam folhas e recebiam tratamento auxínico, a produção de raízes era intensa. Além disso, as estacas foram colocadas para enraizar na ausência e presença de luz, não tendo sido verificado a não-diferença na resposta de enraizamento entre luz e escuro. Dessa forma, os autores concluíram que no enraizamento de estacas as folhas não são importantes para a produção fotossintética de carboidratos, mas sim pela translocação de alguma substância nelas existente, indispensável para o enraizamento. Através da análise química da base das estacas, os autores verificaram serem o conteúdo de açúcares e de nitrogênio solúvel e insolúvel consideravelmente altos, de onde concluíram que o efeito principal das folhas no processo de formação das raízes se dá através do fornecimento de fatores nutricionais para a base das estacas.

Atualmente sabese que os níveis de açúcar e nitrogênio na base das estacas, fornecidos pelas folhas remanescentes, atuam como co-fatores no enraizamento, sendo que o valor de auxina responsável pela formação ou não das raízes adventícias é o fator determinante desse processo. 


\subsection{1 Água, temperatura e substrato}

Dos fatores externos, a água, a temperatura e o substrato são os que merecem uma atenção especial por atuarem no enraizamento de estacas.

Pode-se controlar a taxa de transpiração através da redução da área foliar das estacas, retirando-se as folhas basais e/ou cortando-se as remanescentes pela metade. A necessidade da água para o enraizamento, se fundamenta no fato de que recém colocadas no substrato, ainda não possuem raízes e portanto, não tem como absorver água suficiente para compensar a transpiração e o crescimento de novas brotações. O que foi confirmado no trabalho de Preece \& Read (1993).

A nebulização artificial, além de conservar a umidade elevada, reduz a temperatura da folha mantendo uma película sob a mesma, permitindo a realização do estaqueamento em ambientes de maior luminosidade, não reduzindo a eficiência fotossintética (COSTA, 2000).

A temperatura é outro importante fator que influencia o enraizamento das estacas, por condicionar diretamente o metabolismo das células das folhas e da base das estacas.

Segundo Ruggiero (1987), o substrato é o meio onde ocorre o enraizamento e faz parte desse sistema, disponibiliza água à estacas, permite a penetração das raízes e as trocas gasosas, além de proporcionar um ambiente escuro na base da estaca. $\mathrm{O}$ substrato deve possuir $\mathrm{pH}$ adequado para o desenvolvimento radicular.

Os substratos representam misturas de componentes, geralmente terra, areia, material orgânico, argila, de modo a constituir o meio mais adequado ao enraizamento de estacas, desenvolvimento de plantas e outros propágulos. 
O tamanho das partículas também interfere no enraizamento das estacas. Avanzato \& Cherubini (1993) trabalhando com substratos de perlita com granulometria diferentes obtiveram resultados significativamente superiores com maior granulação. Tal fato está associado com a maior capacidade de retenção de água pela perlita de granulação fina em detrimento àaeração.

Assim, Thompson (1986) trabalhando com diferentes tipos de substratos e pHs obteve os melhores resultados no enraizamento de estacas de Epacris impressa, quando combinou areia e turfa. A utilização de vermiculita não foi adequada ao enraizamento. $\mathrm{O}$ pH 5,1 foi o que melhor favoreceu o enraizamento.

\subsection{Uso de reguladores vegetais como promotores de enraizamento}

O conhecimento de que o tratamento das estacas com auxinas aceleram e estimulam a formação de raízes vêm de longa data. Desde 1938, WENT observou, em estacas de hipocótilo de ervilha (Pisum sativum L.), que o tratamento com auxina levou a aumentar o número de raízes formadas, sendo que o ácido indol-3-acético a $10^{-4} \mathrm{M}$ proporcionou número máximo de raízes. Concentrações acima dessa molaridade são altamente tóxicas, impedindo a formação de raízes. Relata ainda, que tratamentos com altas concentrações de auxinas induzem baixo número de raízes em relação a tratamentos com baixas concentrações. O desenvolvimento só ocorre, quando o excesso de auxina desaparece.

Johnson \& Hamilton (1977), trabalhando com substrato à base de areia, observaram maior porcentagem de enraizamento em estacas de Juniperus conferta quando comparadas com sua mistura com turfa (1:1).

Levando-se em consideração a ação da auxina na formação de raízes adventícias, Ericksen \& Mohammed (1974) citam que, no caso das estacas de ervilha (Pisum sativum L.), as raízes formam-se seguindo as seguintes fases. 
Estádio inicial: onde ocorre a formação de raízes, dividindo-se em: fase de auxinaativa: com duração de poucos dias, cerca de 4, quando a auxina deve ser fornecida continuadamente, via parte aérea ou aplicada na base das estacas; fase de auxina-não-ativa: quando a permanência da auxina não compromete a formação de raízes, com duração aproximada de 4 dias. Estádio de alongamento e crescimento das raízes: quando as raízes crescem através da córtex, emergindo da epiderme do caule. Nesse estádio não há resposta à aplicação de auxinas.

Alguns autores recomendam o tratamento das estacas com auxinas antes do plantio, um deles, Haissig (1972) trabalhando com a aplicação exógena de IAA e/ou GA3 induziu a divisão das células do câmbio em várias espécies, mas somente o IAA promoveu a diferenciação das novas células, levando àformação das raízes. Também afirma que a auxina endógena ou exógena é indispensável para a iniciação de raízes adventícias em segmentos caulinares.

Normalmente, existem dois tipos básicos de aplicação: o uso de baixas concentrações (0 a $500 \mathrm{mg} \cdot \mathrm{L}^{-1}$ ), num tempo de imersão mais rápido (5 a 10 segundos), e o uso de altas concentrações (de 1.000 a $6.000 \mathrm{mg}^{-1} \mathrm{~L}^{-1}$ ), resultando em tratamentos mais caros. A pesquisa mostra resultados satisfatórios com os dois métodos de aplicações (HARTMANN et al., 1990). Nessas duas formas de aplicações das auxinas, a concentração e o tempo de imersão dependem do tipo de estaca, ou seja, estacas lenhosas e semilenhosas, maiores concentrações, e herbáceas, menores concentrações, dentro da faixa acima definida. Na aplicação por baixas concentrações, além da concentração, o tempo de imersão também é definido pelo tipo de estaca. Assim, estacas lenhosas e semilenhosas permanecem nas soluções de tratamento por um tempo mais prolongado; já as herbáceas, por um período de tempo menor, dependendo da espécie estudada.

Existe também um terceiro tipo de aplicação, na forma de pó, que é um método de fácil utilização e possível recomendação, sendo empregado em 
viveiros comerciais através do uso do AIB na concentração de $3.000(0,3 \%)$ a $8.000(0,8 \%) \mathrm{mg}^{-1}{ }^{-1}$ (HEUTHER et al., 1973). Segundo Loach (1988), a aplicação de auxinas na forma de talco não permite precisar a quantidade de produto que passa para os tecidos, dependendo esse fato da condição das estacas e das condições ambientais.

As auxinas podem estimular a atividade cambial, promovendo a formação de calos nas estacas, sendo que tal atividade leva à formação de xilema e engrossamento das paredes celulares, os mesmos autores quando trabalharam com estacas de café (Coffea arabica L.), tratadas ou não com auxinas, observaram nas tratadas intensa formação de calos 22 horas após o tratamento, não sendo constatadas diferenças na estrutura anatômica entre estacas tratas e não tratadas. As estacas que receberam tratamento auxínico apresentaram resposta imediata, mostrando intensa atividade do floema e do câmbio.

Stimart \& Harbage (1993), citados por Costa (2000), estudando o efeito do $\mathrm{pH}$ e do ácido indolbutírico em estacas apicais de macieira 'gala' (Malus doméstica Borkh), não encontraram interação entre o pH e o AIB, assim como influência do pH nas características avaliadas. Já Harbage \& Stimart (1996) em estudos posteriores, demonstraram que a medida que o $\mathrm{pH}$ decrescia, menores quantidades de AIB eram necessárias para provocar um aumento no número de raízes, sendo os melhores resultados obtidos com pH 5,5. Nestas condições a absorção do AIB contido no meio de enraizamento foi maior. 


\subsection{Anatomia e fisiologia do enraizamento}

Poucos estudos têm acompanhado o desenvolvimento do primórdio radicular, desde a divisão celular até a emergência das raízes nas estacas. Vários autores citam que as raízes podem originar-se das células epidérmicas, do córtex, do câmbio, do floema secundário, do periciclo e do cilindro vascular. Estudos que analisam a influência das auxinas, aplicadas exogenamente, sobre a divisão celular e estrutura anatômica, são muito restritos (RODRIGUES \& ONO, 1996).

Inúmeros pesquisadores sugerem a existência de duas fases no processo de iniciação de raízes: a fase de formação do meristema radicular e a fase do crescimento e alongamento das raízes (RODRIGUES \& ONO, 1996). Os mesmos autores relatam que o processo de enraizamento está dividido em 4 estádios: 1. desdiferenciação ou meristematização; 2. iniciação da divisão celular, formando grupos de células organizadas (raízes iniciais); 3. diferenciação do primórdio radicular; 4. alongamento celular e crescimento das raízes.

Trabalhando com estacas de Hibiscus sp., Van Overbeek et al. (1946) observaram que as raízes têm origem no floema secundário, estando esses resultados de acordo com o modelo padrão de iniciação de raízes em caules, nos quais o câmbio é ativo (PRIESTLEY \& SWINGLE, 1929; HAYWARD, 1938).

Segundo Esau (1965), as raízes adventícias, que se desenvolvem nas estacas de muitas plantas, originam-se nas proximidades do tecido vascular diferenciado. Afirma que em estacas de muitas espécies é o primórdio radicular que se forma inicialmente, logo após a confecção dessas estacas. Tais raízes podem desenvolver-se próximas ou na base das estacas.

Fahn (1982) relacionou o fato de algumas estacas enraizarem facilmente devido àpresença de raios vasculares largos, como em Vitis vinifera L. e Tamarix spp. Plantas com raios vasculares estreitos como Cerotonia, Pyrus e Carya sp. enraizam com dificuldade. A iniciação das raízes em pecan (Carya illinoensis 
(Wangenheim) C. Kock.) ocorre na camada externa do parênquima vascular. Essas células possuem atividade cambial, dividindo-se para formar o primórdio radicular. Esse primórdio desenvolve-se tomando a forma de um cálice, empurrando os outros tecidos. Entretanto, somente pequena parte desse primórdio continua penetrando no tecido xilemático, aparentemente devido ao stress mecânico. Com o desenvolvimento, o córtex é rompido e as raízes emergem; nessa fase ainda, não há diferenciação do cilindro vascular onde o AIA é muito requerido (Figura 2).

White \& Lovell (1984) observaram que a iniciação de raízes em estacas de Giselinia littoralis e G. lúcida ocorre próximo ao corte basal, sendo que o primeiro evento observado é a divisão das células cambiais, associando o sítio de iniciação das raízes com o traço foliar. Os autores acreditam também que o fácil enraizamento está associado, primeiramente, com a formação das raízes iniciais. Entretanto, parece provável que o estímulo inicial para a divisão celular venha das folhas, via traço vascular.

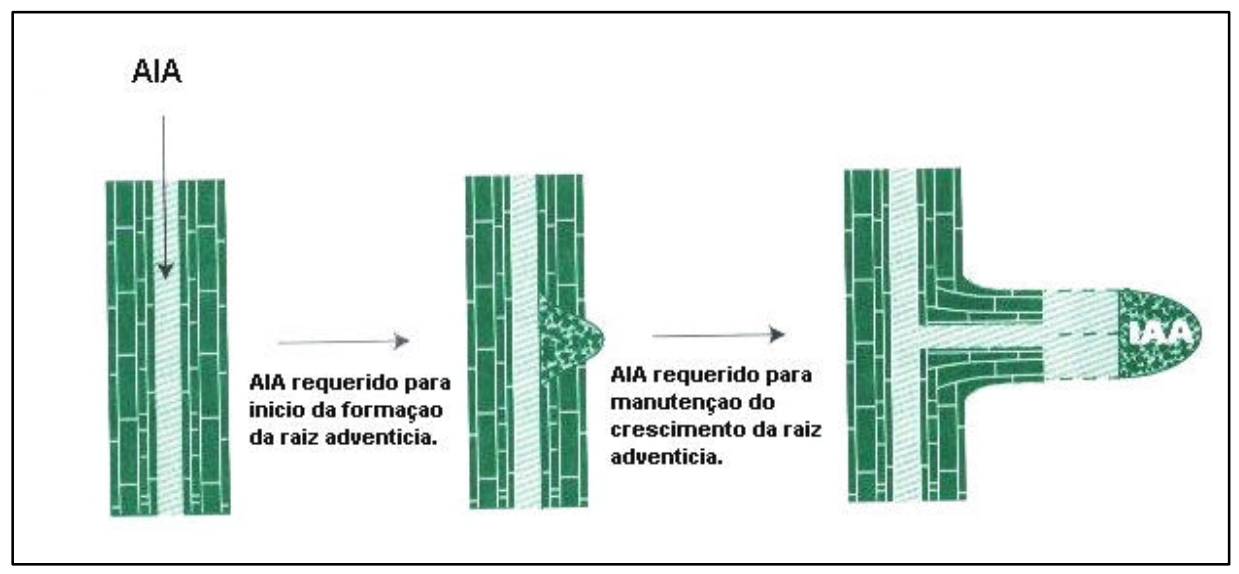

Figura 2 - Modelo de Desenvolvimento de raiz em estacas (AFTER CELENZA et al., 1995, adaptado por TAIZ \& ZEIGER, 1998) 
Segundo Almeida ${ }^{3}$ existem nas estacas as chamadas células alvo, que após receberem o estímulo, sofrem a desdiferenciação seguido pela diferenciação, tornando-se determinadas e em seguida formam as raízes laterais, conforme mostrado na Figura 2.

Williams et al. (1984) observaram que o baixo enraizamento em muitas espécies lenhosas está mais correlacionado com a suberização do córtex, do que com a inibição através da esclerificação. Sugerem alguns pré-requisitos para o enraizamento, que são: a) capacidade e receptividade das células parenquimáticas para regenerar regiões meristemáticas; b) modificações da auxina e sistemas de enzimas e c) necessidade de "substratos", como o acúmulo de carboidratos e mudanças no conteúdo de nitrogênio e aminoácidos.

Brutsch et al., citado por Rodrigues \& Ono (1996), trabalhando com estacas caulinares de Carya illinoensis (Wangenheim) C. Kock.), observaram que 20 dias após o plantio das estacas, houve intumescimento da base e, logo depois, formação de calos em muitas delas. O primórdio radicular foi visualizado após 4 a 5 semanas. Invariavelmente, o calo originou-se do câmbio, próximo ao xilema. Apontaram, no caso de Pinus radiata D. Don., estar a formação do primórdio radicular associada com divisões rápidas dos meristemas e, portanto, a duração do estágio de iniciação é muito breve. Muitas vezes, as raízes podem originar-se do calo, o qual se forma a partir do câmbio, próximo aos traços foliares e às gemas.

Rodrigues \& Ono (1996), relatam ainda que em estacas caulinares de café, o calo é formado, principalmente, pela divisão das células do câmbio e do floema, mas pode ser ariginado também das células do periciclo, córtex e medula. A formação do calo se efetua, geralmente, antes da iniciação e do desenvolvimento das raízes. O início das raízes ocorre, normalmente, junto ao corte basal e logo acima, em muitos casos desenvolvendo intercâmbio entre o tecido do calo e 0

\footnotetext{
${ }^{3}$ Ibid, 2002.
} 
tecido de iniciação de raízes, muito raramente se formando raízes diretamente do calo. Sabe-se muito sobre os efeitos dos fatores internos e externos que interferem no enraizamento das estacas, mas se desconhecem as razões pelas quais algumas células se dividem originando raízes e em outras não.

$\mathrm{Na}$ Figura 3 obseva-se uma raiz lateral originada através da diferenciação das células do periciclo. Em estacas caulinares ocorre a desdiferenciação de algumas células as quais adquirem características com funções de periciclo, levando a formação de raízes adventícias.

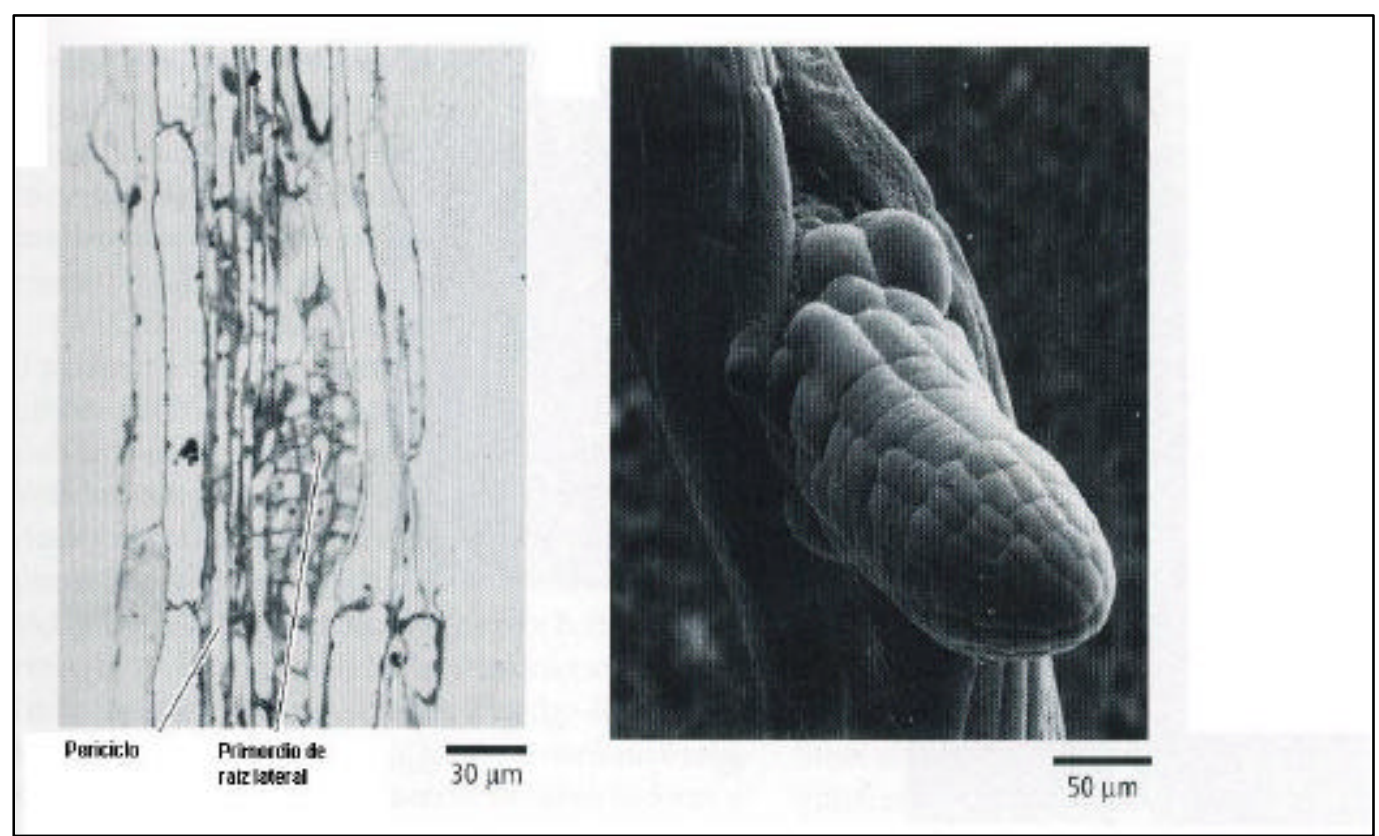

Figura 3 - Raízes laterais originadas da diferenciação do periciclo em Arabidopsis (DOLAN et al., 1993, adaptado por TAIZ \& ZAIGER, 1998)

Carrera Garcia (1977), citado por Silva (1985), diz que o calo é uma formação regenerativa que ocorre, principalmente, pelo estímulo da atividade cambial, tendo origem nas células da região do câmbio vascular e do floema. A rapidez na formação do calo, muitas vezes, determina o êxito do plantio das estacas, porém, nem sempre, está relacionada com a formação de raízes, uma 
vez que são processos fisiológicos independentes. As raízes podem originar-se a partir de primórdios radiculares desenvolvidos previamente, ou mais tarde, de acordo com as condições do ambiente. As células que formam o primórdio radicular são derivadas do parênquima interfascicular em ramos novos, e dos raios vasculares em ramos mais velhos.

Lee et al. (1982), em estacas de Phaseolus aureus Roxb., verificaram que as raízes tiveram origem das células do parênquima floemático, entre os feixes vasculares. Cortes transversais da base dessas estacas, tratadas com ANA (Ácido Naftaleno-Acético), mostraram características anatômicas semelhantes àquelas tratadas com água, sendo a única diferença observada na divisão celular, que foi mais nítida nas estacas tratadas.

Blazick \& Heus (1979), em estacas de Phaseolus aureus Roxb., observaram que não houve diferença no tempo de início da divisão celular, entre as estacas tratadas e não tratadas com ANA. Os autores sugerem que o avanço do primórdio radicular necessita dos tecidos adjacentes para uma opção enzimática e física. Enzimática, por destruir as células corticais, abrindo espaços para o desenvolvimento do primórdio radicular.

Segundo Almeida ${ }^{4}$, dois mecanismos gerais da auxina sobre a formação de raízes podem ser identificados: 1. a auxina determina quais células alvo irão se diferenciar em raízes iniciais; 2. as auxinas promovem o subseqüente desenvolvimento de raízes iniciais predeterminadas.

Hartmann et al. (1990) relatam que em lenho perene, onde já estão presentes xilema e floema secundários, as raízes adventícias tem origem, geralmente, do tecido jovem do floema secundário, mas também podem originarse dos raios vasculares, câmbio, ou dos calos produzidos na base das estacas.

\footnotetext{
${ }^{4}$ Ibid, 2002.
} 
Em estudos sobre a origem e o desenvolvimento de raízes adventícias em limas (Citrus limettioides T.), El-Tomi \& Galal (1980) constataram que secções transversais e longitudinais da base de estacas semilenhosas e do tecido do calo de lima (Citrus limettioides T.) mostraram a presença de dois tipos de raízes. Um deles iniciado das células dos calos, e outro próximo aos feixes vasculares, na região entre o câmbio e o periciclo, nas células parenquimatosas, embora a maioria delas tenha se originado dos tecidos dos calos.

Segundo Messina \& Testolini (1984), células do câmbio vascular proliferam e se diferenciam, dando origem à nova raiz. Os calos aparecem devido à atividade do câmbio e do felogênio. Outra região que tem sua atividade meristemática ativada é o felogênio das lenticelas.

Além da produção de mudas por estaquia, foi dada atenção especial na revisão de literatura sobre as técnicas usadas na avaliação da diversidade genética.

\subsection{Técnicas de uso corrente na avaliação da diversidade genética}

Na primeira metade da década de 80 , surgiu um método que se baseia na amplificação de seqüência de DNA: a Reação de polimerase em cadeia (PCR Polymerase Chain Reaction). Neste método, a enzima polimerase replica seqüências de DNA em condições controladas a partir de um par de pequenos fragmentos iniciadores ("primers") que flanqueiam a seqüência que se deseja amplificar. Através de variações alternadas e cíclicas de temperatura, que permitem a desnaturação (abertura da fita dupla de DNA), anelamento (pareamento dos "primers") e extensão (cópia da fita dupla original pela incorporação de nucleotídeos nas fitas complementares). Após o processo, uma determinada seqüência de DNA é amplificada, ciclo após ciclo, em progressão 
geométrica, o que torna possível sua visualização em gel de eletroforese em forma de uma banda (MULLIS et al., 1994).

Para certos tipos de análise, a reação de PCR específica apresenta um grande fator limitante: o uso em larga escala requer o conhecimento dos nucleotídeos que compõem as duas extremidades da seqüência de DNA que se deseja amplificar. Assim o conhecimento é que o par de "primers" que flanqueiam uma região-alvo no DNA pode ser sintetizado e utilizado na amplificação desta seqüência através da reação em cadeia da polimerase (MULLIS et al., 1994).

No início da década de 90, foi proposta uma alternativa para contornar o problema do conhecimento prévio da seqüência de DNA que se deseja amplificar, possibilitando a utilização da técnica em organismos onde nenhum conhecimento de seqüência de DNA existia. Neste caso utiliza-se apenas um "primer" (decâmero) na reação de PCR, alterando também as condições específicas de amplificação da reação. Esta variação possibilita que ocorra amplificação ao acaso de segmentos de DNA no genoma. A amplificação é função da probabilidade de, após a desnaturação da fita dupla de DNA, existir no genoma uma seqüência complementar ao "primer" em uma das fitas e, a uma distância que possa ser percorrida pela polimerase, uma outra seqüência complementar ao "primer" na fita oposta. Portanto, esta reação ocorre devido ao anelamento do "primer" único em pontos próximos do genoma, delimitando a região que será amplificada (FERREIRA \& GRATTAPAGLIA, 1996).

Esta técnica foi desenvolvida independentemente por dois grupos nos Estados Unidos. Williams et al. (1990) patentearam a tecnologia com nome mais comumente utilizado, RAPD ("Random Amplified Polymorphic DNA"), ou DNA polimórfico amplificado ao acaso. Neste trabalho clássico, os autores descreveram a técnica no contexto da análise Mendeliana, demonstrando a identificação de marcadores genéticos para mapeamento. Welsh \& McClelland (1990), por sua vez, propuseram a denominação mais apropriada para a técnica, 
chamando-a de AP-PCR ("Arbitrarily Primed-Polymerase Chain Reaction") uma vez que os "primers" possuem seqüência arbitrária mas a amplificação tecnicamente não ocorre ao acaso e sim em lugares específicos no genoma. experimento relatado foi essencialmente a geração de "fingerprins" (impressões digitais) genômicos simples e reproduzíveis para a identificação de linhagens, utilizando géis de eletroforese em poliacrilamida de maior poder de resolução juntamente com "primers" um pouco mais longos.

Segundo Ferreira \& Grattapaglia (1996), independentemente do nome utilizado e das pequenas variações na metodologia, a técnica de PCR utilizando "primers" de seqüência arbitrária abriu uma perspectiva inteiramente nova para a análise genômica de indivíduos e populações. Além de facilitar e acelerar os estudos que já ocorriam com as espécies mais tradicionais (ex. milho, tomate, arroz) a tecnologia RAPD trouxe uma verdadeira "democratização" da análise de polimoirfismo molecular, ao permitir a realização de estudos de análise genética em espécies anteriormente não contempladas. Desde sua descrição, o uso de marcadores RAPD na análise genética e no melhoramento de plantas tem tido uma difusão extremamente rápida. As aplicações incluem: obtenção de "fingerprints" genômicos de indivíduos, variedades e populações, análise de estrutura e diversidade genética em populações naturais, populações de melhoramento e bancos de germoplasma, estabelecimento de relações filogenéticas entre diferentes acessos, construção de mapas genéticos de alta cobertura genômica e a localização de genes de interesse econômico (WILLIAMS et al., 1993). 


\section{INFLUÊNCIA DE SUBSTRATOS, VALORES DE PH, CONCENTRAÇÕE DE AIB NA PROPAGAÇÃO DA JABUTICABEIRA (Myrciaria jaboticaba (Vell) Berg.) ATRAVÉS DE ESTACAS APICAIS.}

\subsection{Introdução}

A Jabuticabeira é uma espécie da família Myrtaceae e gênero Myrciaria, tem o Brasil como centro de origem e dispersão natural (PIO CORRÊA, 1984).

A produção de mudas comerciais de jabuticabeiras ainda é, essencialmente por sementes. Nesse caso, apesar da característica poliembriônica e apomítica das sementes proporcionar a obtenção de plântulas de origem nucelar (51\% para o cultivar Sabará), que conservam a identidade da planta matriz (ANDERSEN \& ANDERSEN, 1988), a longa fase juvenil, levando até mais de dez anos para iniciar sua produção, persiste. Para evitar esse longo período juvenil, pode-se optar pelos métodos tradicionais de propagação como enxertia e estaquia (SCARPARE et al., 2002).

A Jabuticabeira é uma planta de difícil enraizamento das estacas caulinares (SCARPARE et al., 2002), por isso o método tradicionalmente usado na propagação vegetativa é o método da enxertia.

Apesar da dificuldade de enraizamento de estacas em jabuticabeiras, alguns autores (DUARTE et al., 1997; SCARPARE FILHO et al., 1999; SCARPARE et al, 2002), já obtiveram resultados positivos quando trabalharam com estacas não lignificadas folhosas, tratadas com regulador vegetal (ácido indol butírico-AIB).

Duarte et al. (1997) trabalhando com estacas terminais folhosas de jabuticabeiras em diferentes estádios de desenvolvimento, três tipos de substrato 
(areia, turfa e uma combinação de ambos, ambientes de enraizamento (nebulização intermitente e câmara de polietileno hermeticamente fechada sob $50 \%$ de sombreamento) e estimuladores de enraizamento (AIB nas concentrações de 0;1000; 3000 e 8000 mg/ $/ \mathrm{L}^{-1}$ com e sem feridas na base da estaca), concluíram que o melhor substrato para o enraizamento das estacas foi a mistura de turfa com areia, a melhor estaca foi obtida com corte terminal de $10 \mathrm{a}$ $12 \mathrm{~cm}$ logo abaixo do nó, com 3 a 4 pares de folhas terminais recentemente maduras; aquelas com folhas muito jovens não enraizaram muito bem. $O$ melhor estímulo foi o AIB $1000 \mathrm{mg} \cdot \mathrm{L}^{-1}$ e somente o ferimento na base da estaca proporcionou a mesma significância na taxa de enraizamento. Todos os resultados foram obtidos na câmara hermeticamente fechada, pois interrupções contínuas na corrente elétrica e água demasiadamente fria, fizeram com que os tratamentos com nebulização intermitente não dessem resultados significativos.

Os autores concluíram ainda que na câmara hermeticamente fechada as estacas enraizaram com porcentagens de 13.2, 22.6 e 30.8 para os substratos em areia, turfa e suas misturas (50\%) respectivamente. A turfa prejudicou o enraizamento provavelmente por reter muita água e a areia por não reter água suficiente para abastecer a estaca nos intervalos sem irrigação.

Na câmara hermeticamente fechada, nos meses muito frio (Dezembro e Janeiro) era feito um aquecimento para manter o substrato com 30 a $35^{\circ} \mathrm{C}$ e a temperatura do ar com 27 a $32^{\circ} \mathrm{C}$ com $100 \%$ de umidade. Esse microclima favoreceu o ataque de fungos em decorrência do longo período de condução do experimento, mas não interferiu no enraizamento das estacas (DUARTE et al., 1997).

Scarpare Filho et al. (1999) nas condições de Piracicaba-SP, trabalhando com estacas herbáceas de Jabuticabeira Sabará de 12 anos de idade, podadas drasticamente na altura de $1 \mathrm{~m}$ do solo no mês de março, com o objetivo de forçar o rejuvenescimento nos tecidos da planta. Colheram estacas em pleno 
desenvolvimento vegetativo e preparadas com $10 \mathrm{~cm}$ de comprimento com 2 pares de folhas na porção apical. As estacas foram colocadas em imersão rápida (5 segundos) em água destilada e na solução de ácido indolbutírico (AIB), nas concentrações de 1000, 2000, 4000 e $8000 \mathrm{mg}$. L-1 , em seguida, foram colocadas em bandejas de isopor, que continham vermiculita, dispostas em nebulização intermitente.

Os mesmos autores, após 180 dias verificaram que não houve nenhum enraizamento nas estacas sem promotor de enraizamento (com somente água destilada), mas, quando as estacas foram mergulhadas na solução que continha ácido indolbutírico (AIB), apresentaram um enraizamento de 8,96\%; 12,88\%; $23,16 \%$ e $37,98 \%$ nas concentrações de $1000,2000,4000$ e $8000 \mathrm{mg} \cdot \mathrm{L}^{-1}$ respectivamente.

De uma maneira geral, mais de $50 \%$ das estacas tratadas com AlB mantiveram-se vivas até o final do experimento, e as estacas tratadas somente com água destilada apenas $1 \%$ mantiveram-se vivas até o término da pesquisa. As estacas tratadas com AIB apresentaram somente uma raiz por estaca.

Scarpare et al. (2002), trabalhando com 3 diferentes tipos de estacas de Jabuticabeira "Sabará" (Herbácea, semilenhosa com estiolamento e semilenhosas sem estiolamento) e diferentes valores de AIB, concluíram que as diferentes concentrações de AIB não influenciaram estatisticamente no enraizamento das estacas, mas que a capacidade de enraizamento de estacas caulinares de Jabuticabeira "Sabará" está relacionada com o estádio de desenvolvimento (lignificação) dos ramos, visto que o enraizamento nas estacas herbáceas foi significativamente superior æ̀ estacas semilenhosas com e sem estiolamento. Neste trabalho os autores obtiveram média de $23 \%$ de enraizamento de estacas para as estacas herbáceas. 
Como para a maioria das espécies de plantas as estacas enraízam com 20 a 40 dias, muitos pesquisadores abandonam o experimento antes do enraizamento das estacas de jabuticabeiras, visto que nessas estacas 0 surgimento de primórdios radiculares aparecem a partir dos 100 ou 120 dias.

O objetivo do presente trabalho foi verificar o efeito do substrato, $\mathrm{pH}$ e suas interações com a utilização do ácido indolbutírico no enraizamento de estacas apicais de jabuticabeiras.

\subsection{Material e Métodos}

As estacas foram coletadas de plantas matrizes de Myrciaria caulifloraBerg., que se encontravam no pomar de jabuticabeiras do Departamento de Produção Vegetal da Escola Superior de Agricultura "Luiz de Queiroz", em Piracicaba-SP. As plantas usadas como matrizes apresentavam 14 anos de idade e foram podadas tipo taça com brotações na base da planta (Figura 4). 


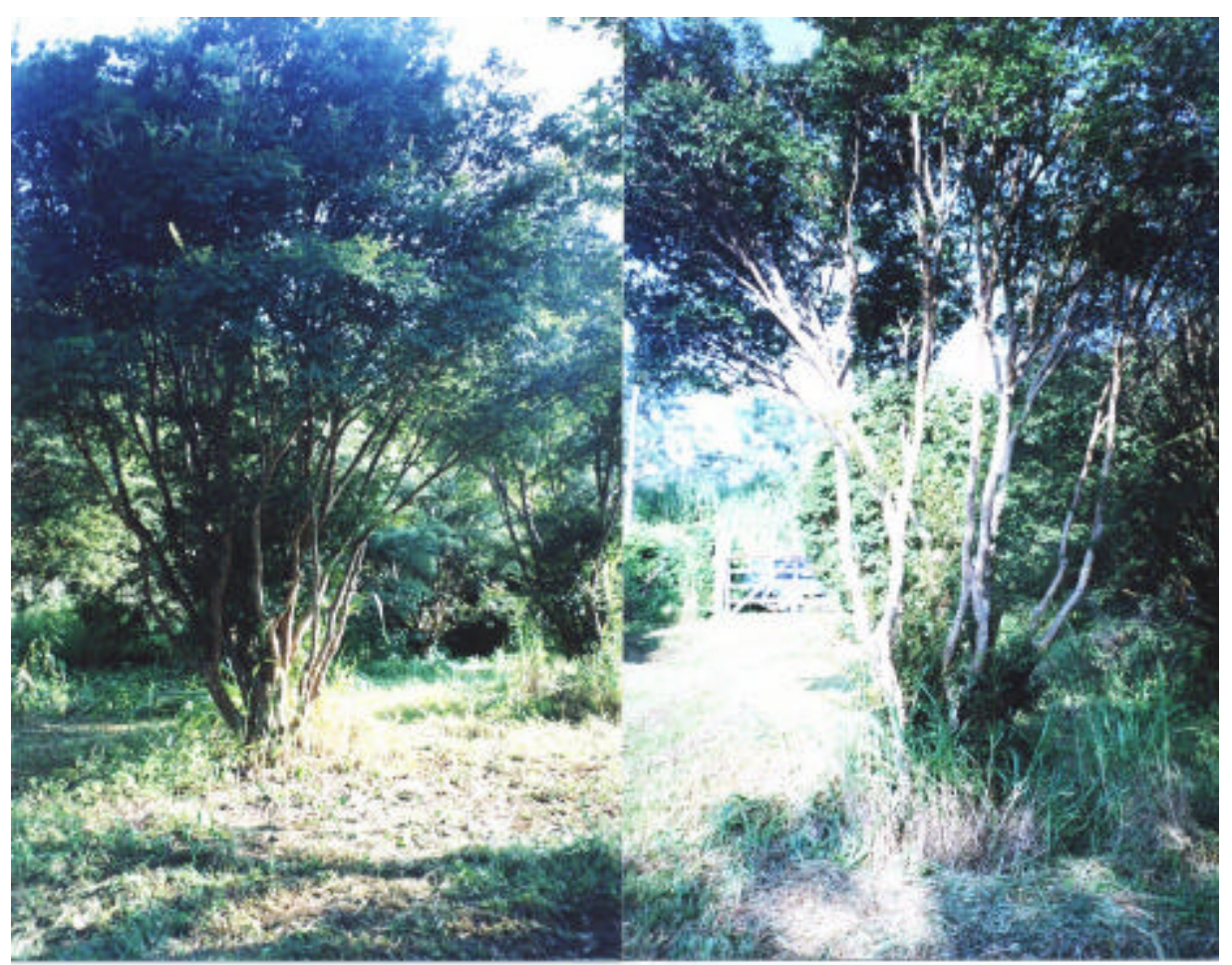

Figura 4 - Vista das árvores matrizes de jabuticabeiras dos quais foram coletadas as estacas apicais 
As estacas apicais foram coletadas no dia 10/04/2002 \&̀s 7:00 hs, os dados climáticos do mês de abril estão expressos na Figura 5.

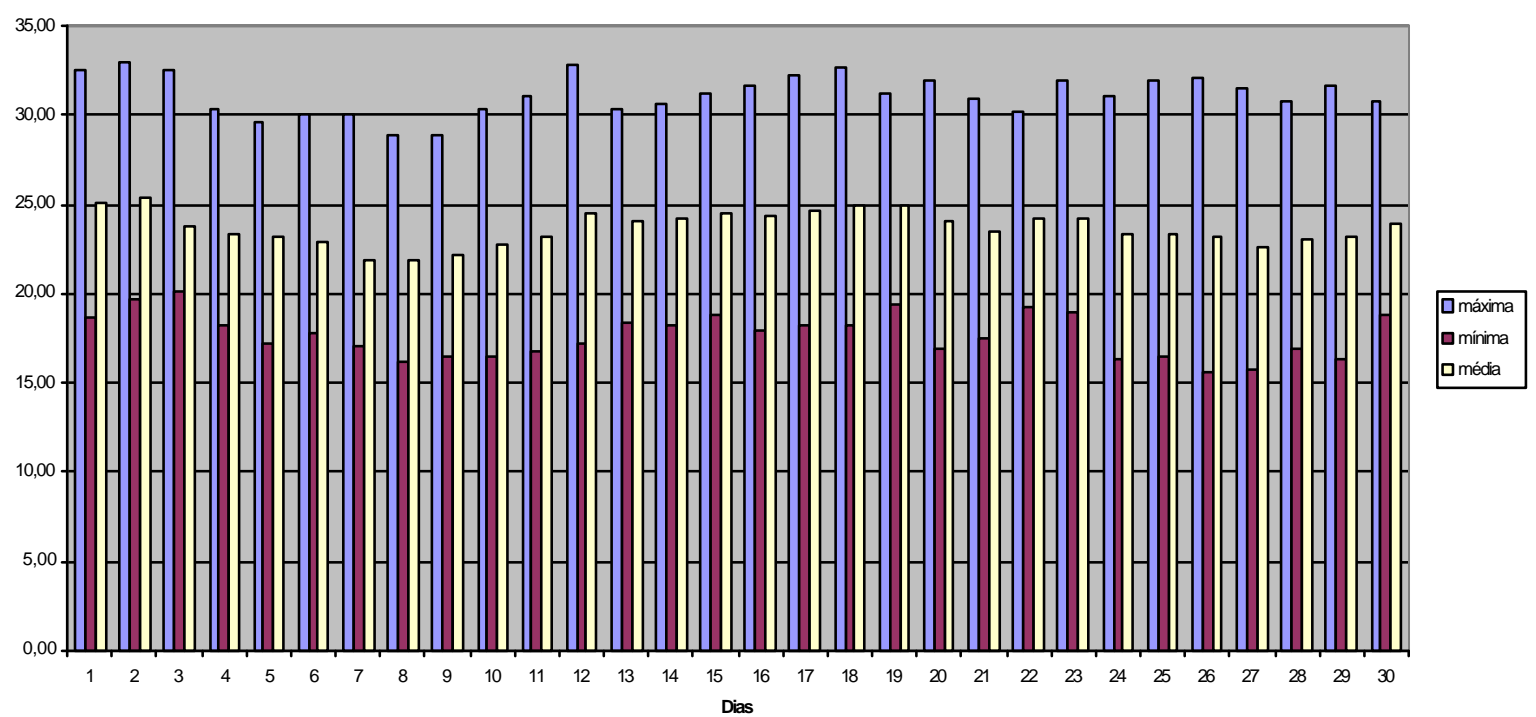

Figura 5 - Dados diários das temperaturas máximas, médias e mínimas, do mês de abril de 2002. Dados coletados no Posto Agrometeorológico do Departamento de Ciências Exatas - ESALQ - USP

A coleta das estacas apicais foi feita com auxílio de uma tesoura de poda, escolhendo-se ramos externos de brotações herbáceas com 0,2 a 0,3 cm de diâmetro e comprimento de $15 \mathrm{~cm}$.

Após a coleta as estacas apicais foram acondicionadas em béqueres contendo água destilada e colocadas em isopor, transportadas até o Laboratório de Botânica da Faculdade de Agronomila "Dr. Francisco Maeda" (20ํ21' 14" S; 47 46' 25' W; 713 m), em Ituverava -SP, onde foram preparadas e estaqueadas nos substratos.

$\mathrm{Na}$ preparação, para evitar a transpiração excessiva, as folhas foram cortadas ao meio com uma tesoura bem afiada para evitar que as mesmas rasgassem (Figura 6). 


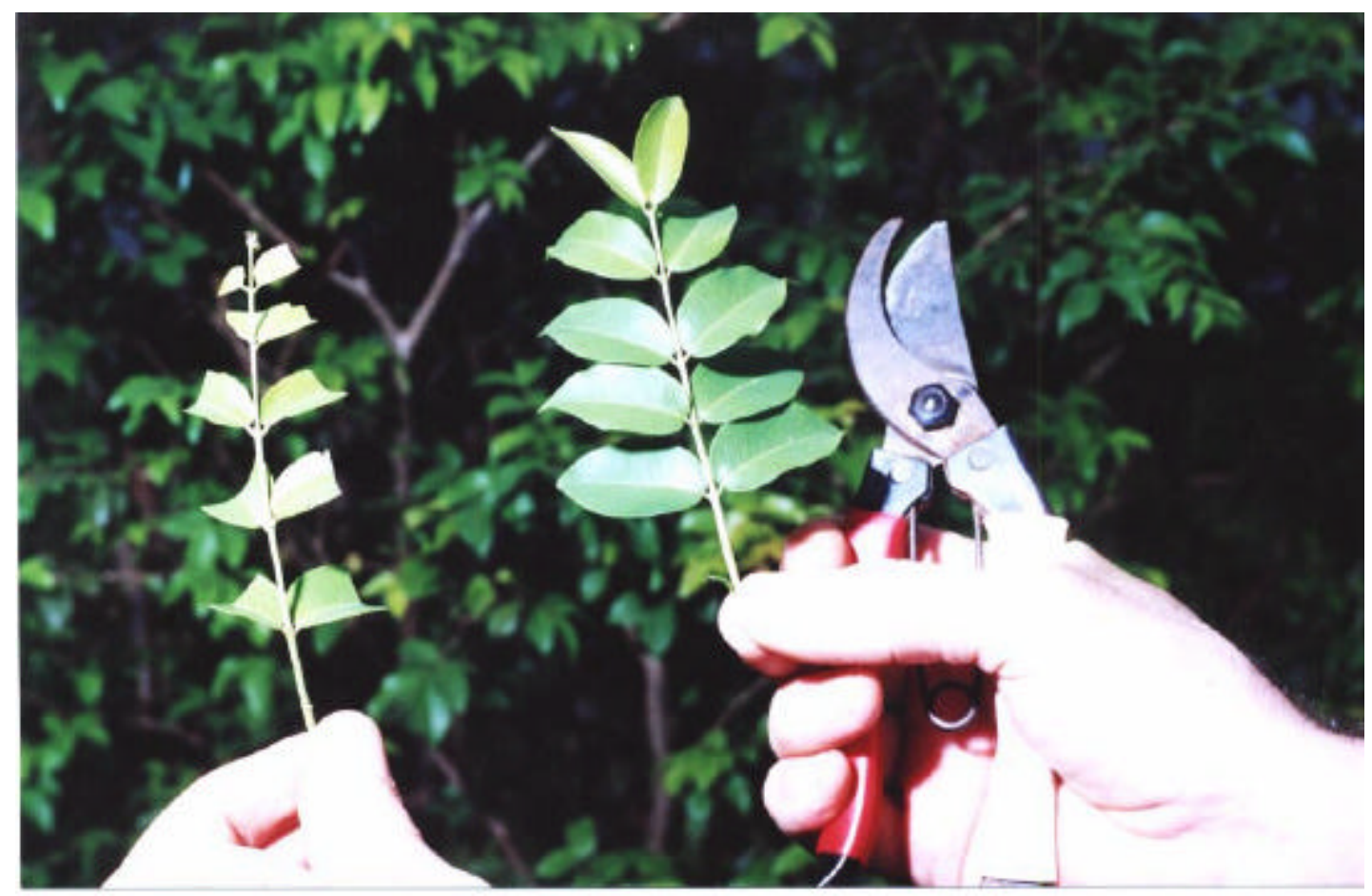

Figura 6 - Estacas apicais de jabuticabeiras sendo coletadas e preparadas para receberem a pasta auxínica

A pasta auxínica foi preparada no Laboratório de Fisiologia de Árvores do Curso de Engenharia Florestal da ESALQ - Piracicaba - SP. A auxina, depois de pesada, foi diluída em etanol 92,8º , na proporção de 1,0 mg de AIB / 0,1 ml de álcool. A diluição foi realizada, colocando-se metade do etanol restante. A solução foi agitada com bastão de vidro, até a completa dissolução do fitohormônio. Em seguida essa foi vertida em lanolina, sendo obtida a pasta para aplicação na base das estacas. A preparação foi feita no mesmo dia da aplicação na base das estacas.

Neste experimento, foram utilizados dois tipos de substrato, a vermiculita, que pode ser o resultado da expansão por aquecimento da mica, sendo, portanto estéril. Apresenta densidade muito baixa, de 90 a $150 \mathrm{Kg}$ por $\mathrm{m}^{3}$, tem reação neutra e grande capacidade de reter cátions. Absorve de 3 a 4 vezes a sua massa em água, sendo insolúvel neste meio (HARTMAN et al., 1990). O outro substrato 
foi a areia grossa que foi previamente lavada e posteriormente esterilizada com brometo de metila.

Após serem lavados em água destilada, os substratos tiveram seus pHs ajustados para valores de 3,5; 4,5; 5,5; e 6,5. Para se fazer o ajuste, foram colocados em solução com água e ácido fosfórico diluído, sendo os valores do pH ajustado com pHmetro digital, adicionando-se o ácido fosfórico diluído até o valor desejado.

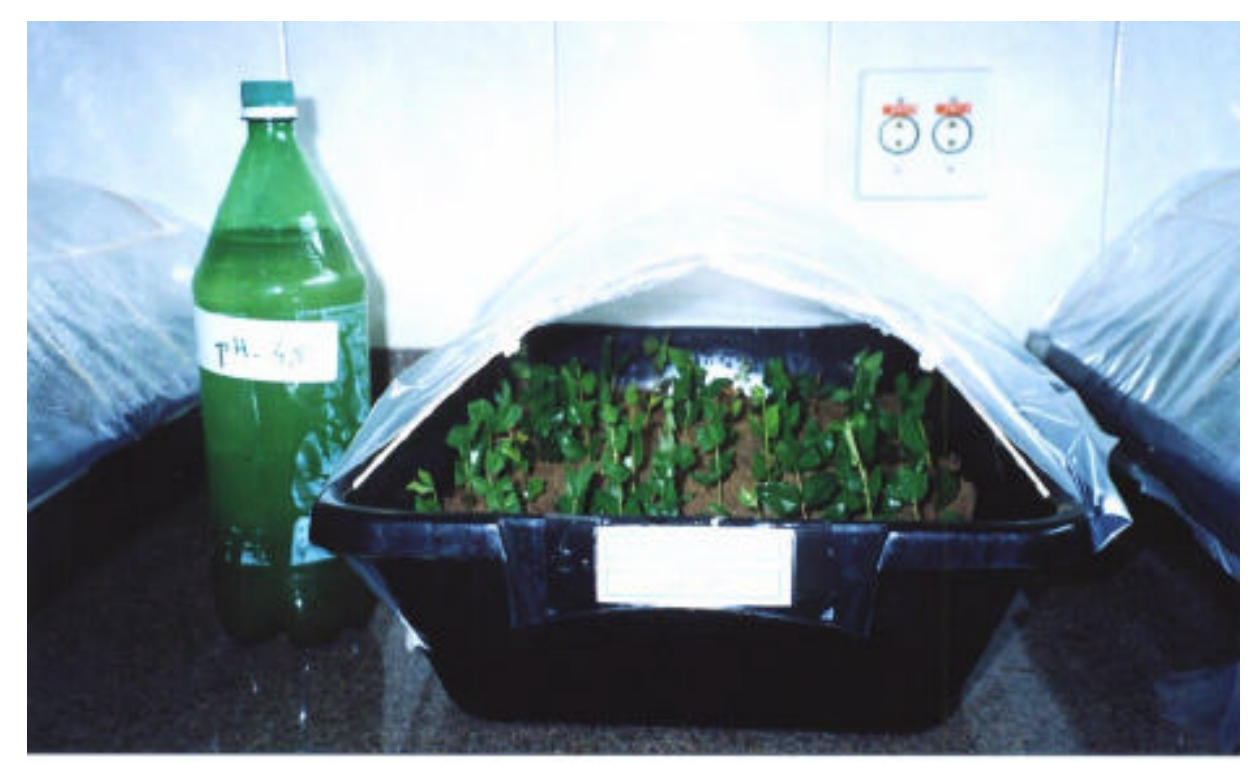

Figura 7 - Vista dos estufins abertos para serem pulverizados com soluções de pH correspondente ao do substrato

Utilizourse bandejas plásticas de $90 \times 12 \times 30 \mathrm{~cm}$, preenchidas com os substratos nos quais foram colocadas as estacas. Cada bandeja foi dividida ao meio com uma proteção vedada com cola de silicone para separação dos substratos (Figura 7). Cada bandeja conteve uma repetição por substrato, de diferentes tratamentos, dispostos ao acaso. Cada tratamento, para evitar a difusão e contaminação dos valores de AIB, foi isolado com uma proteção vedada com cola de silicone. Cada subparcela foi composta por 10 microestacas. 
Adotourse o delineamento de subparcelas subsubdivididas $2 \times 4 \times 5$, onde os substratos areia grossa e vermiculita constituíram as parcelas ou unidades inteiras, os pHs $(3,5 ; 4,5 ; 5,5$; e 6,5$)$ constituíram os quatro níveis, os valores de $\operatorname{AIB}\left(0 ; 1000 ; 2000 ; 4000\right.$ e $\left.6000 \mathrm{mg} \cdot \mathrm{L}^{-1}\right)$ as subsubparcelas.

O ambiente junto as estacas apicais foi mantido sob nebulização durante 0 período de enraizamento, em estufins feitos nas próprias bandejas. Cada bandeja era coberta com plástico PEBD (polietileno de baixa densidade) de 100 micras de espessura, a cobertura em arco ficava a uma altura de $25 \mathrm{~cm}$ do valor do substrato. Para se manter a umidade relativa no interior do estufim em torno de 90\%, eram realizadas de duas a três pulverizações diárias.

Para se manter o $\mathrm{pH}$ dos substratos constante, foram preparadas soluções, de água e ácido fosfórico diluído ajustadas com os respectivos $\mathrm{pHs}$, as quais eram usadas nas pulverizações (Figura 8). Os pHs dos substratos foram monitorados a cada 15 dias, ajustando-os aos valores iniciais.

Todos os estufins foram colocados em balcões próximos æ̀s janelas do laboratório, onde recebiam luz difusa pelo menos durante 6 horas por dia (Figura 8).

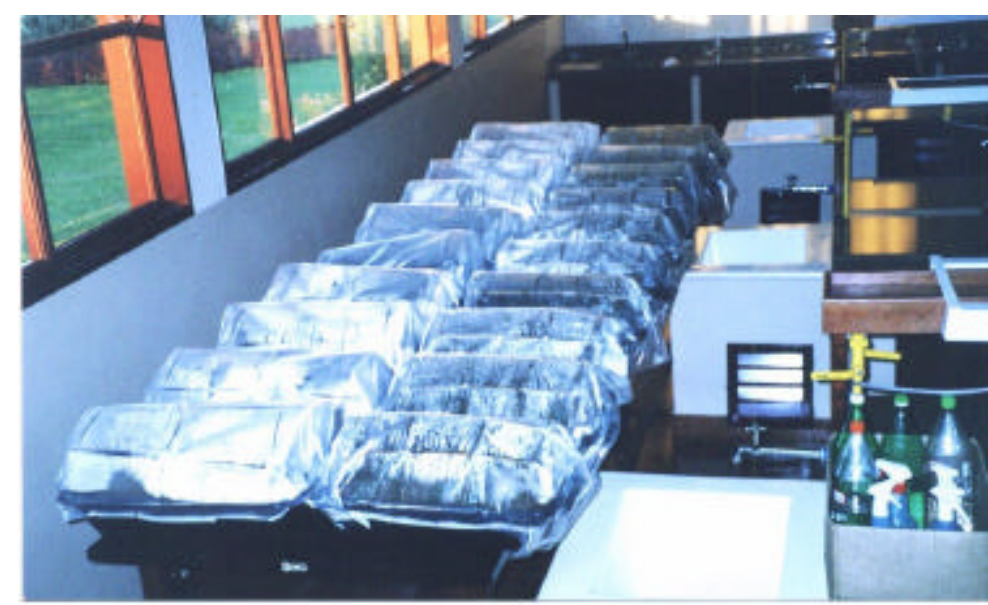

Figura 8 - Vista geral dos estufins 
As temperaturas máxima, média e mínima, foram monitoradas dentro e fora dos estufins durante a condução do experimento, sendo expressas nas Figuras 9 e 10.

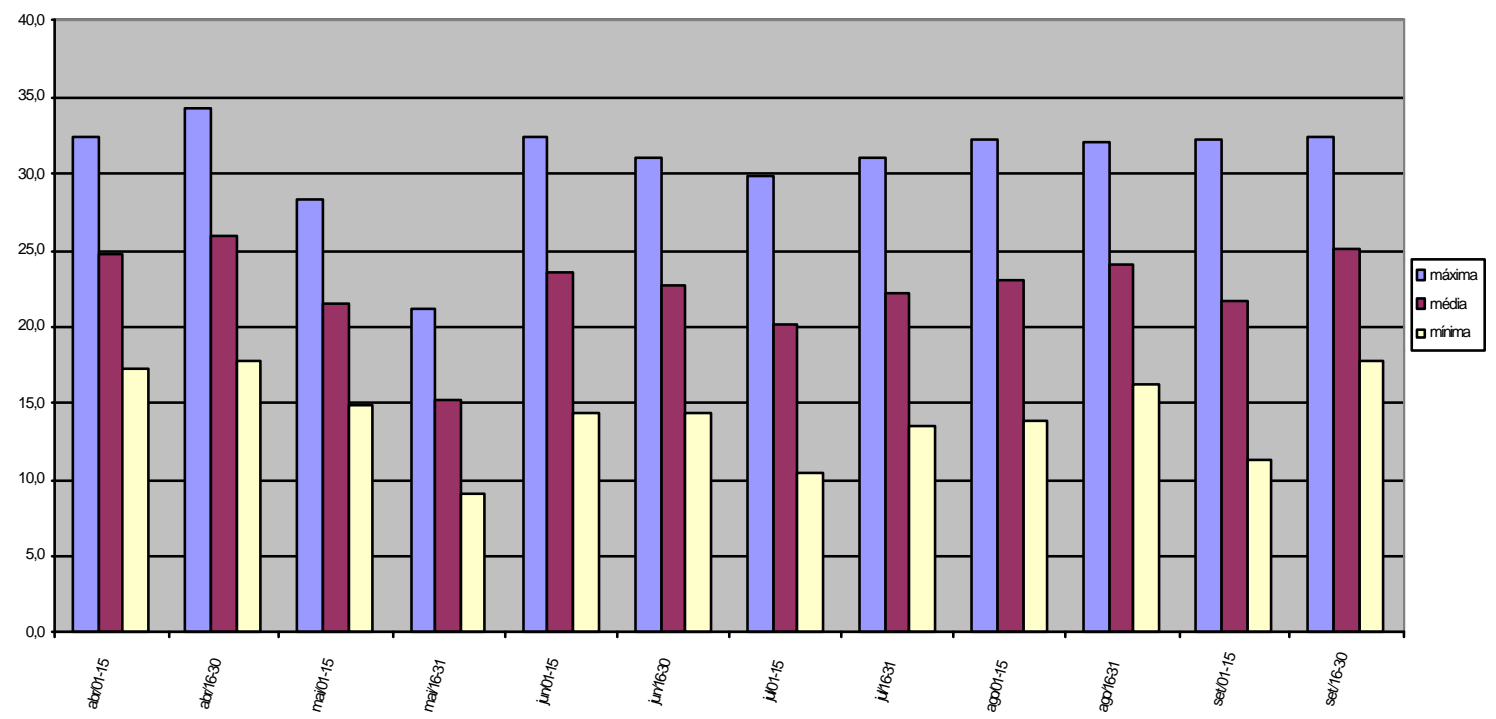

Figura 9 - Dados diários, expressos em médias quinzenais, das temperaturas máximas, médias e mínimas, durante a condução do experimento na Faculdade de Agronomia de Ituverava (Fafram) * Dados obtidos do Departamento de Engenharia Rural

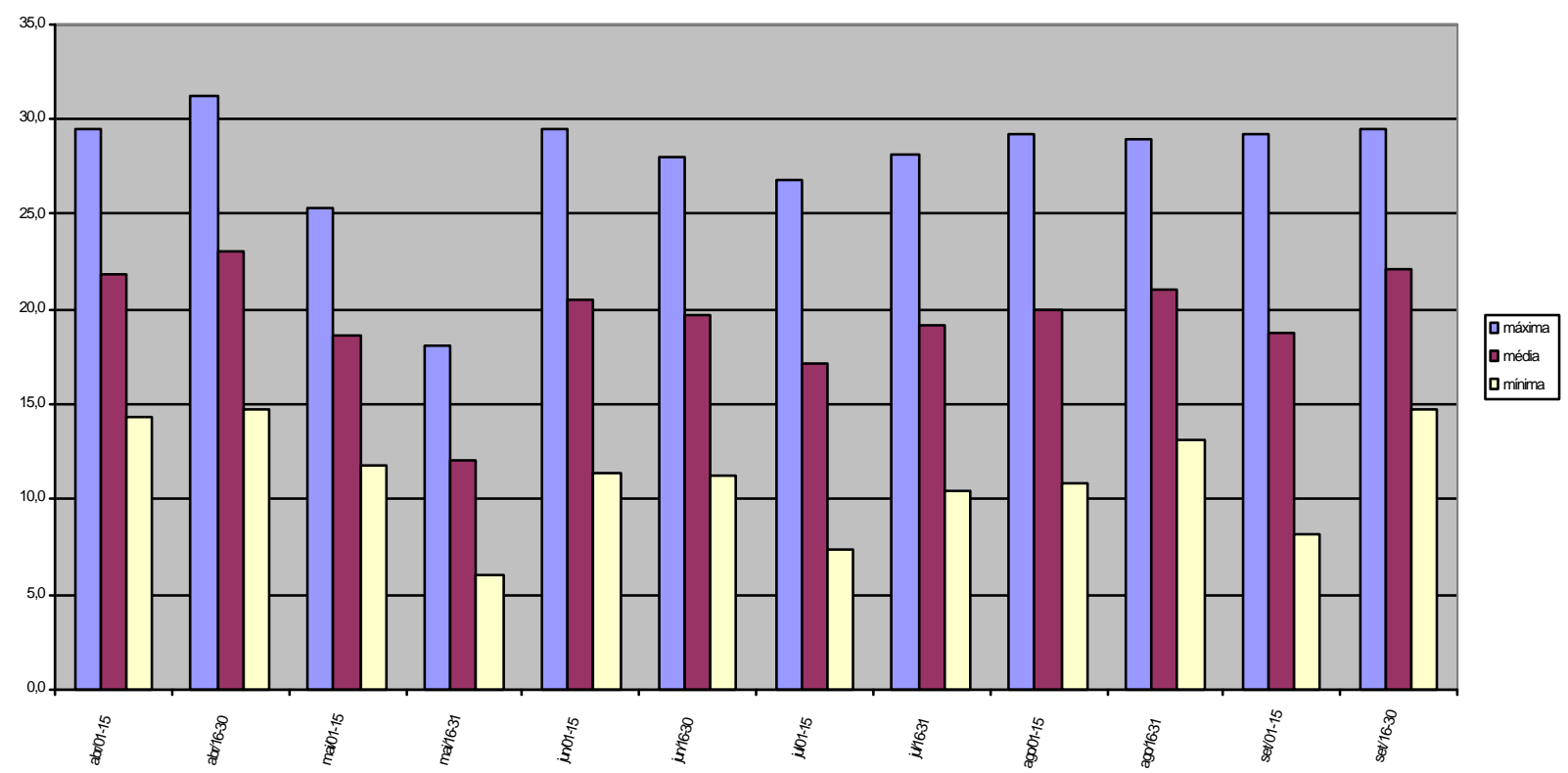

Figura 10 - Dados diários, expressos em médias quinzenais, das temperaturas máxima, média e mínima no interior do estufim 
Após 180 dias, avaliou-se o número de estacas vivas e o número de estacas enraizadas. Foram consideradas estacas vivas aquelas que possuíam folhas e a base não apresentasse necrose. Qualquer emissão de raiz era considerada estaca enraizada.

Os dados foram submetidos àanálise de variância e as médias comparadas pelo teste Tukey, ao valor de $5 \%$ de probabilidade. Os dados coletados foram transformados, utilizando-se arco seno SQRT $(x+0,098)$.

\subsection{Resultado e Discussão}

De acordo com a análise estatística dos resultados expressos na Tabela 1, verifica-se que o enraizamento das estacas apicais de jabuticabeira Sabará foi estatisticamente significativo para o substrato areia grossa quando comparado com o substrato vermiculita.

Como o substrato faz parte do sistema, integrante no enraizamento de estacas (RUGGIERO, 1987), essa melhor taxa de enraizamento pode estar relacionada com um melhor contato das partículas do substrato com a base das estacas. Resultados semelhantes foram obtidos por JOHNSON \& HAMILTON em 1977, trabalhando com estacas de Juniperus conferta quando comparados com o substrato a base de turfa.

O tipo de substrato não interferiu significativamente na porcentagem de estacas vivas. 
Tabela 1. Efeito do substrato, valores de pH e concentrações de AIB no enraizamento e sobrevivência de estacas apicais de jabuticabeiras (Myrciaria spp) 'Sabará'

\begin{tabular}{|c|c|c|c|c|c|c|c|c|c|c|c|c|c|c|}
\hline Substratos & $\begin{array}{c}\% \\
\text { enraiz. } \\
\left(^{* \star}\right)\end{array}$ & $\left({ }^{*}\right)$ & $\begin{array}{c}\text { estacas } \\
\text { vivas } \\
\left(^{* \star}\right)\end{array}$ & $\left(^{*}\right)$ & $\mathrm{pH}$ & $\begin{array}{c}\% \\
\text { enraiz. } \\
\left(^{* \star}\right)\end{array}$ & $\left({ }^{*}\right)$ & $\begin{array}{c}\text { estacas } \\
\text { vivas } \\
\left(^{* \star}\right)\end{array}$ & $\left({ }^{*}\right)$ & $\begin{array}{c}\text { AIB } \\
\left(m g \cdot L^{-1}\right)\end{array}$ & $\begin{array}{c}\% \% \\
\text { enraiz. } \\
\left(^{* \star}\right)\end{array}$ & $\left(^{*}\right)$ & $\begin{array}{c}\text { estacas } \\
\text { vivas } \\
\left(^{\star \star}\right)\end{array}$ & $\left({ }^{*}\right)$ \\
\hline $\begin{array}{l}\text { areia } \\
\text { grossa }\end{array}$ & $33,52 a$ & $(20,69)$ & $33,04 a$ & $(19,93)$ & 3,5 & $28,39 c$ & $(12,81)$ & $30,73 b$ & $(16,31)$ & 0 & $31,08 a$ & $(16,85)$ & $32,59 a$ & $(19,21)$ \\
\hline \multirow{3}{*}{ Vermiculita } & & & & & 5,5 & $35,18 b$ & $(23,39)$ & $42,08 a$ & $(35,11)$ & 2000 & $31,75 a$ & $(17,89)$ & $32,30 a$ & $(18,75)$ \\
\hline & & & & & 6,5 & $25,84 c$ & $(9,19)$ & $29,82 b$ & $(14,93)$ & 4000 & $31,35 a$ & $(17,27)$ & $33,16 a$ & $(20,12)$ \\
\hline & & & & & & & & & & 6000 & $31,75 a$ & $(17,89)$ & $32,12 \mathrm{a}$ & $(18,47)$ \\
\hline DMS & 1,98 & & 1,84 & & & 4,33 & & 4,00 & & & 4,39 & & 4,51 & \\
\hline CV (\%) & 12,24 & & 11,32 & & & 21,23 & & 19,59 & & & 19,58 & & 20,05 & \\
\hline
\end{tabular}

* Dados originais

** Dados transformados, utilizando-se arco seno SQRT $(X+0,098)$

OBS: Let ras diferentes numa mesma coluna indicam diferenças entre as médias. 
A taxa de sobrevivência das estacas apicais também apresentou um melhor resultado para os valores de $\mathrm{pH} 4.5$ e 5.5 quando comparados com os valores de pH 6.5 e 3.5, apesar dos dois últimos não diferirem estatisticamente entre si. A maior taxa de mortalidade foi observada no $\mathrm{pH} 6.5$ e no substrato vermiculita (apesar de não diferir do substrato areia). Tal fato pode estar relacionado com a grande capacidade da vermiculita em reter água, o que pode ter favorecido um maior contato da solução com a base da estaca, estimulando as reações enzimáticas que desencadearam a necrose das mesmas, associado ao fato de que este valor de $\mathrm{pH}$ pode estimular a ação das enzimas AIA-oxidase.

Pode ser observado também na Tabela 1 e 2 que o melhor $\mathrm{pH}$ para induzir o enraizamento foi 4.5 , os pHs inferiores e superiores com valores de 3.5 e 6.5, respectivamente, foram os que estatisticamente proporcionaram uma menor porcentagem de enraizamento nas estacas apicais. $\mathrm{OpH}$ com valor 5.5 apesar de induzir uma menor taxa de enraizamento quando comparado com o $\mathrm{pH}$ de valor 4.5, foi superior àtaxa de enraizamento dos pHs com valores 3.5 e 6.5. Esses resultados, estão relacionados, possivelmente, com a ação enzimática que controla o processo de desdiferenciação e diferenciação das células. As enzimas cujas atividades são inibidas com baixos e altos valores de pH, são responsáveis, por destruir as células corticais, abrindo espaços para o desenvolvimento do primórdio radicular (BLAZICK \& HEUSER, 1979).

As diferentes concentrações de AIB (ácido indol butírico) não interferiram estatisticamente no enraizamento das estacas (Tabela 1). Os dados desse trabalho estão de acordo com os obtidos por Scarpare et al. (2003), porém diferem de Scarpare Filho et al. (1999) e Duarte et al. (1997). Esses autores verificaram que o enraizamento de estacas não lignificadas da jabuticabeira só foi conseguido com o uso de regulador vegetal.

A interação entre o tipo de substrato usado e os valores de $\mathrm{pH}$, só foram estatisticamente significativas para os $\mathrm{pHs}$ de valores 4.5 e 5.5 para areia grossa 
e 4.5 para vermiculita (Tabela 2). Essa interação indica que esses valores podem favorecer sobre as reações químicas (enzimáticas) nos tecidos localizados na base das estacas responsáveis pela formação dos primórdios radiculares.

Tabela 2 . Efeito da interação dos diferentes valores de pH e dos substratos na porcentagem de enraizamento de estacas apicais de jabuticabeiras 'Sabará'

\begin{tabular}{ccccc}
\hline PH & $\begin{array}{c}\text { Substratos } \\
\text { a enraizamento }\end{array}$ & \multicolumn{3}{c}{$\begin{array}{c}\text { vermiculita } \\
\text { \% enraizamento }\end{array}$} \\
& $\left(^{* *}\right)$ & $\left({ }^{* *}\right)$ & $\left({ }^{* \star}\right)$ & $\left({ }^{* *}\right)$ \\
3,5 & $30,02 \mathrm{~b}$ & $(15,23)$ & $26,76 \mathrm{~b}$ & $(10,47)$ \\
4,5 & $38,72 \mathrm{a}$ & $(29,32)$ & $40,45 \mathrm{a}$ & $(32,29)$ \\
5,5 & $39,78 \mathrm{a}$ & $(31,16)$ & $30,58 \mathrm{~b}$ & $(16,08)$ \\
6,5 & $25,56 \mathrm{~b}$ & $(8,8)$ & $26,12 \mathrm{~b}$ & $(9,58)$ \\
DMS & 6,1238 & & 6,1238 & \\
$\mathrm{~F}$ (trat.) & $20,18^{*}$ & & $18,67^{*}$ & \\
\hline
\end{tabular}

*** Dados originais

** Dados transformados, utilizando-se arco seno SQRT $(X+0,098)$

* Significativo ao nível de $1 \%$ de probabilidade pelo teste Tukey (5\%)

OBS: Letras diferentes numa mesma coluna indicam diferenças entre as médias.

De acordo com os dados da Tabela 2, pode-se observar que a melhor interação que houve entre o substrato areia, e os diferentes valores de $\mathrm{pH}$ foram os de 4.5 e 5.5, já para o substrato vermiculita o melhor valor de $\mathrm{pH}$ foi o 4.5 . Esses resultados estão de acordo com os obtidos por Thompsom (1986), quando trabalhou com estacas de Epacris impressa, com pH 5.1, para o substrato, obtendo os melhores resultados para o enraizamento.

Para melhor visualização e interpretação os dados expressos na Tabela 2, estão apresentados na forma gráfica nas Figuras 11, 12 e 13. 
$\mathrm{Na}$ Figura 11 observa-se que o processo de enraizamento segue uma tendência polinomial de ordem 2 , sendo que para 0 intervalo do $\mathrm{pH}$ (3.5 $<x<6,5)$, os melhores valores de $\mathrm{pH}$ para indução de formação de raízes são os de valores 4.5 e 5.5 para os dois substratos usados.

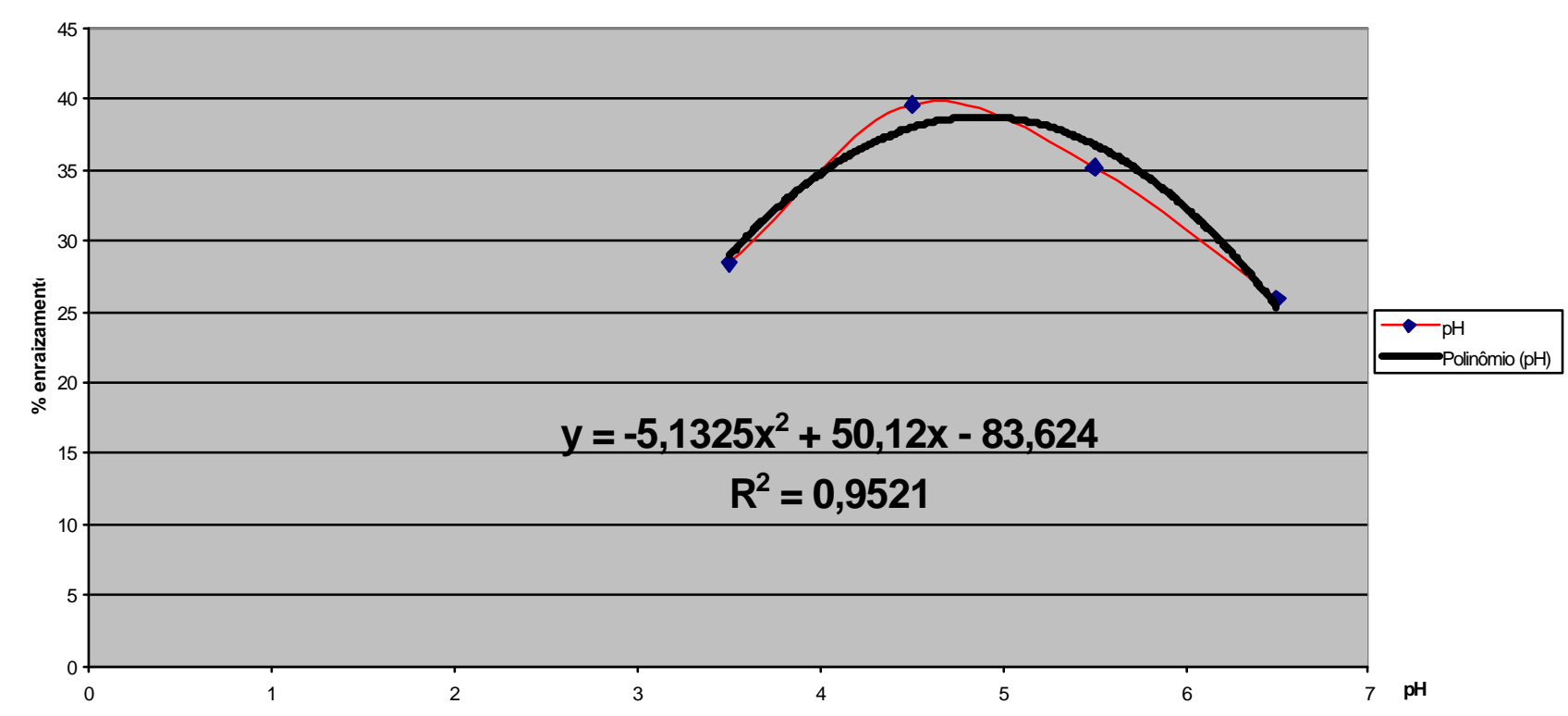

Figura 11 - Interação dos diferentes valores de $\mathrm{pH}$ e dos substratos (areia grossa e vermiculita) na porcentagem de enraizamento de estacas apicais de jabuticabeira 'Sabará'

Os dados ajustados mostram que se os valores de $\mathrm{pH}$ tenderem a reduzir para valores menores que 4.5 e maiores que 5.5, a porcentagem de enraizamento reduzirá; isso pode estar relacionado com um maior índice de absorção de AIB contido no meio enraizador, proporcionado pelas condições de pHs com valores de 4.5 e 5.5. Dados semelhantes foram obtidos opor Harbage \& Stimart (1966) quando trabalharam com estacas pouco lignificadas de macieira gala (Malus doméstica Borkh).

Como o substrato é o local onde as estacas estão fixadas, servindo de fonte de água e nutrientes, no qual estão localizados os fatores estimulantes do enraizamento, a variação do valor de seu $\mathrm{pH}$, é um fator que exerce forte influência no metabolismo na base das estacas, podendo estimular ou inibir 
processos enzimáticos que favorecem a desdiferenciação e diferenciação de células alvo que vão formar os primórdios radiculares.

Quando se compara a linha de tendência, através da regressão polinomial dos dados, para a interação dos valores de $\mathrm{pH}$ na taxa de enraizamento, os dois substratos separadamente apresentam um ajuste diferente da linha de tendência. Através da análise da Figura 12 pode-se observar que o processo de enraizamento em função do $\mathrm{pH}$ para o substrato pode ser representado por uma equação polinominal do tipo $y=-5,73 x^{2}+56,068 x-96,407$ e $R^{2}=0,9794$, sendo que a interseção das linhas ocorre no pH de valor 4.8 (intervalo entre 4.5 e 5.5), indicando que o melhor $\mathrm{pH}$ para induzir o enraizamento em estacas de Jabuticabeira é esse valor.

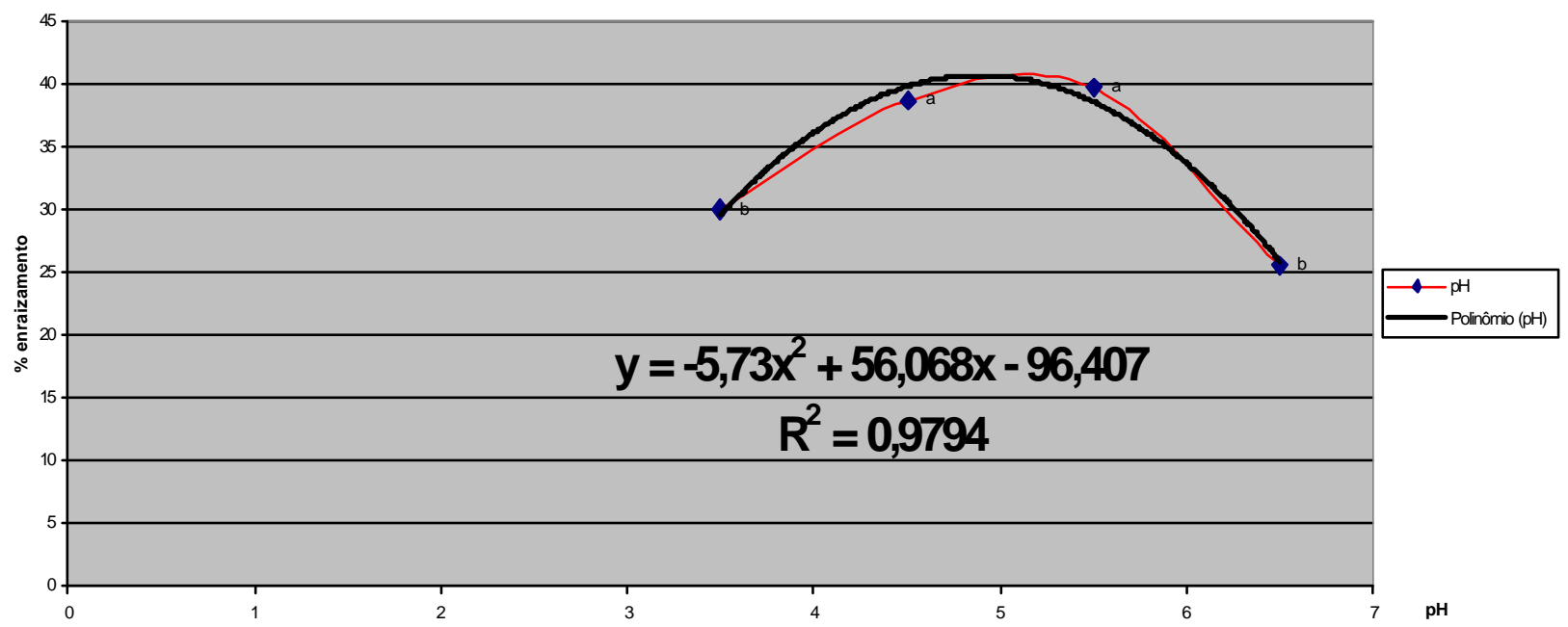

Figura 12 - Interação dos diferentes valores de pH e do substrato areia grossa na porcentagem de enraizamento de estacas apicais de Jabuticabeira 'Sabará'

Pela análise da Figura 13, pode-se observar que os dados não são bem ajustáveis àlinha de tendência obtida através da regressão linear quadrática. 


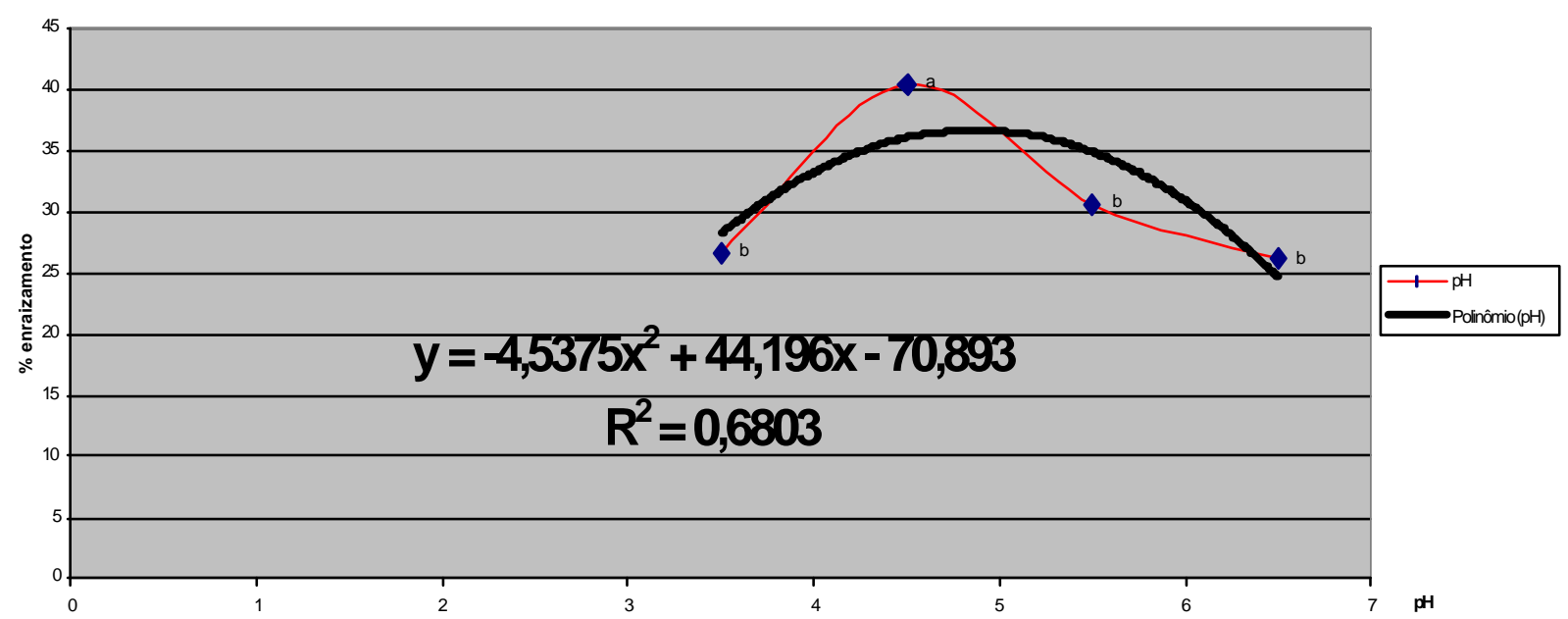

Figura 13 - Interação dos diferentes valores de $\mathrm{pH}$ e do substrato vermiculita na porcentagem de enraizamento de estacas apicais de Jabuticabeira 'Sabará'

Neste caso, embora a porcentagem de enraizamento em função do valor do $\mathrm{pH}$ seja representada por uma regressão polinomial $y=-4,5375 x^{2}+44,196 x$ - 70,893 e $R^{2}=0,6803$, no intervalo $(3,5<x<6,5)$, a relação não é tão estreita como no caso da areia grossa. Dessa maneira, outros fatores como o contato das partículas de vermiculita com a base das estacas e outros fatores não avaliados podem ter afetado esta relação.

Alguns fatores, como a liberação de $A \mathrm{~A}^{\beta+}$ do substrato para solução, provavelmente provocada pela ação do baixo valor do $\mathrm{pH}$ (3.5), pode ter induzido um efeito fitotóxico, necrozando a base das estacas, impedindo a emissão de primórdios radiculares.

Valores elevados de $\mathrm{pH} \geq 7.0$, podem estimular as enzimas AlA-oxidase, inibindo a ação das auxinas exógenas, podendo ser explicado desta maneira 0 baixo enraizamento das estacas submetidas ao $\mathrm{pH} 6.5$.

Observa-se nas duas figuras abaixo, 14 e 15, que apesar de não ter ocorrido a formação de raízes na base das estacas, ocorreu a formação de calos e as estacas permaneceram vivas, mesmo após ter decorridos 180 dias. 

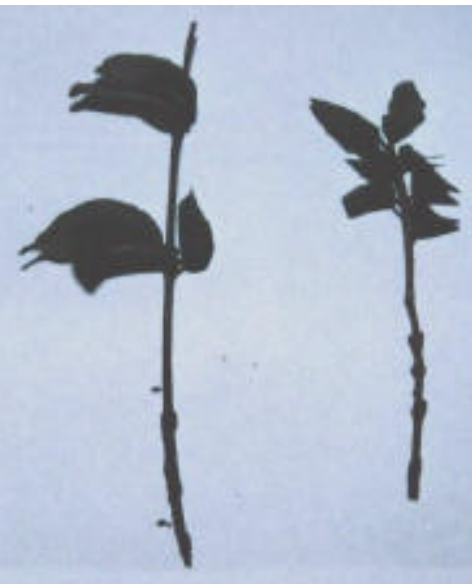

Figura 14 - Estacas apicais de Jabuticabeira com $0 \mathrm{mg} \cdot \mathrm{L}^{-1}$ de AIB, no substrato areia grossa e pH 3.5 aos 180 dias, com formação calos e sem formação de raízes adventícias

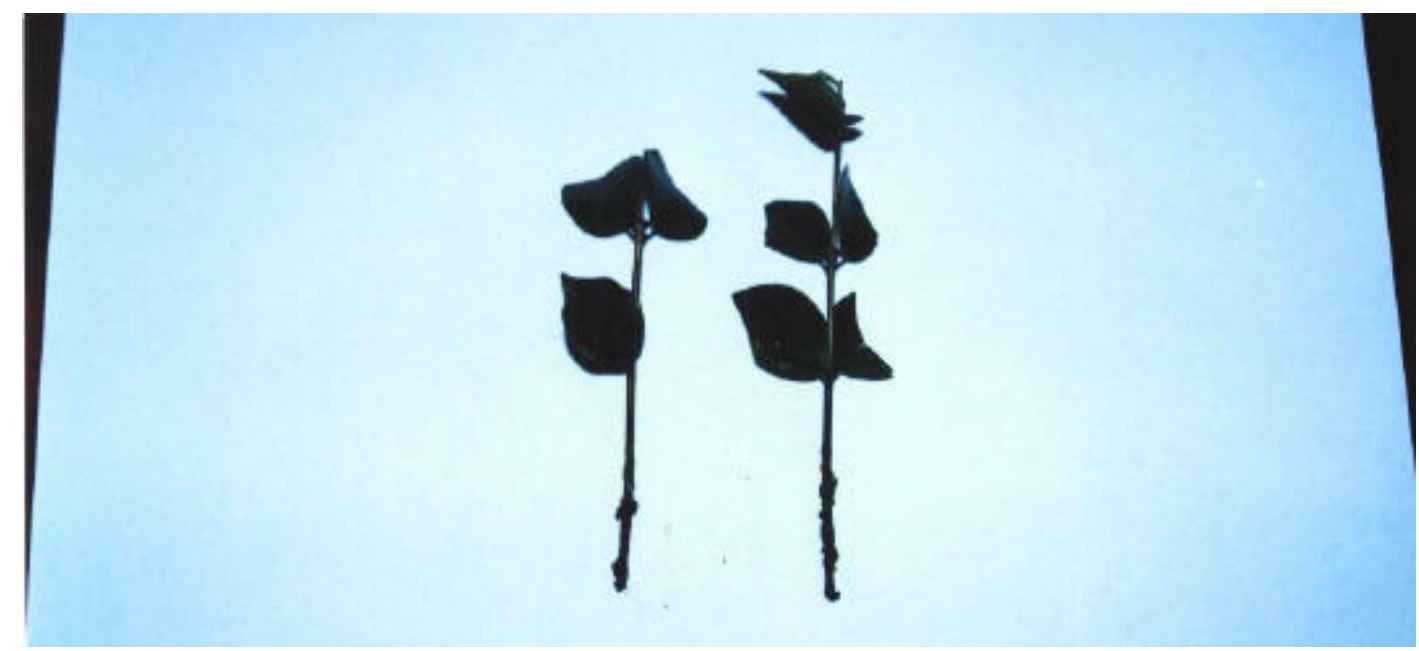

Figura 15 - Estacas apicais de Jabuticabeira com $0 \mathrm{mg}^{-L^{-1}}$ de AIB, no substrato vermiculita e pH 3.5 aos 180 dias, apresentando formação de calos na região basal

Observa-se na figura 16, a formação de raiz adventícia, cerca de $3 \mathrm{~cm}$ acima da base da estaca, local onde foi aplicado a pasta auxínica. Provavelmente o efeito tóxico da alta concentração de auxina (4.000 mg. $\left.\mathrm{L}^{-1}\right)$, no local de aplicação, tenha estimulado a emissão de raiz nessa região. 
Pode-se observar também a emissão de um broto lateral na região do nó da primeira folha remanescente.

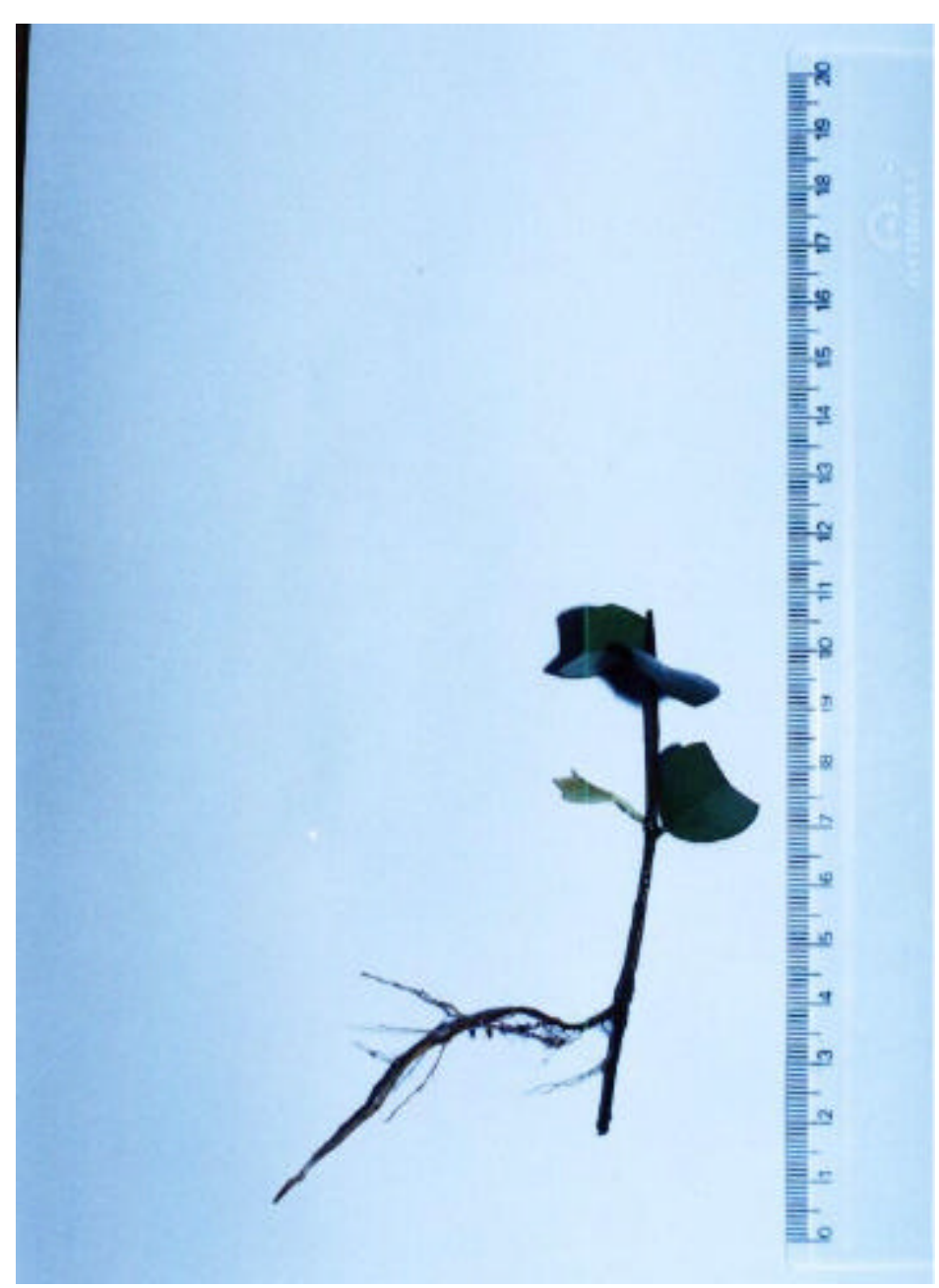

Figura 16 - Estaca apical de Jabuticabeira com $4000 \mathrm{mg} \cdot \mathrm{L}^{-1}$ de AIB, no substrato vermiculita e pH 4.5 aos 180 dias, apresentando a formação de uma vigorosa raiz adventícia e de uma brotação vegetativa lateral 
Pode ser observado nas figuras 17 e 18, que as raízes formadas na base das estacas, colocadas no mesmo substrato, areia grossa, são mais vigorosas quando estão submetidas a um $\mathrm{pH}$ de menor valor (4.5), quando comparado com $\circ \mathrm{pH}$ de valor 5.5. Esse maior vigor pode estar associado com a interferência do pH sobre a absorção de AIB, estando de acordo com o que Stimart \& Harbage (1993) observaram em estacas de maça Gala (Malus domestica Borkh).

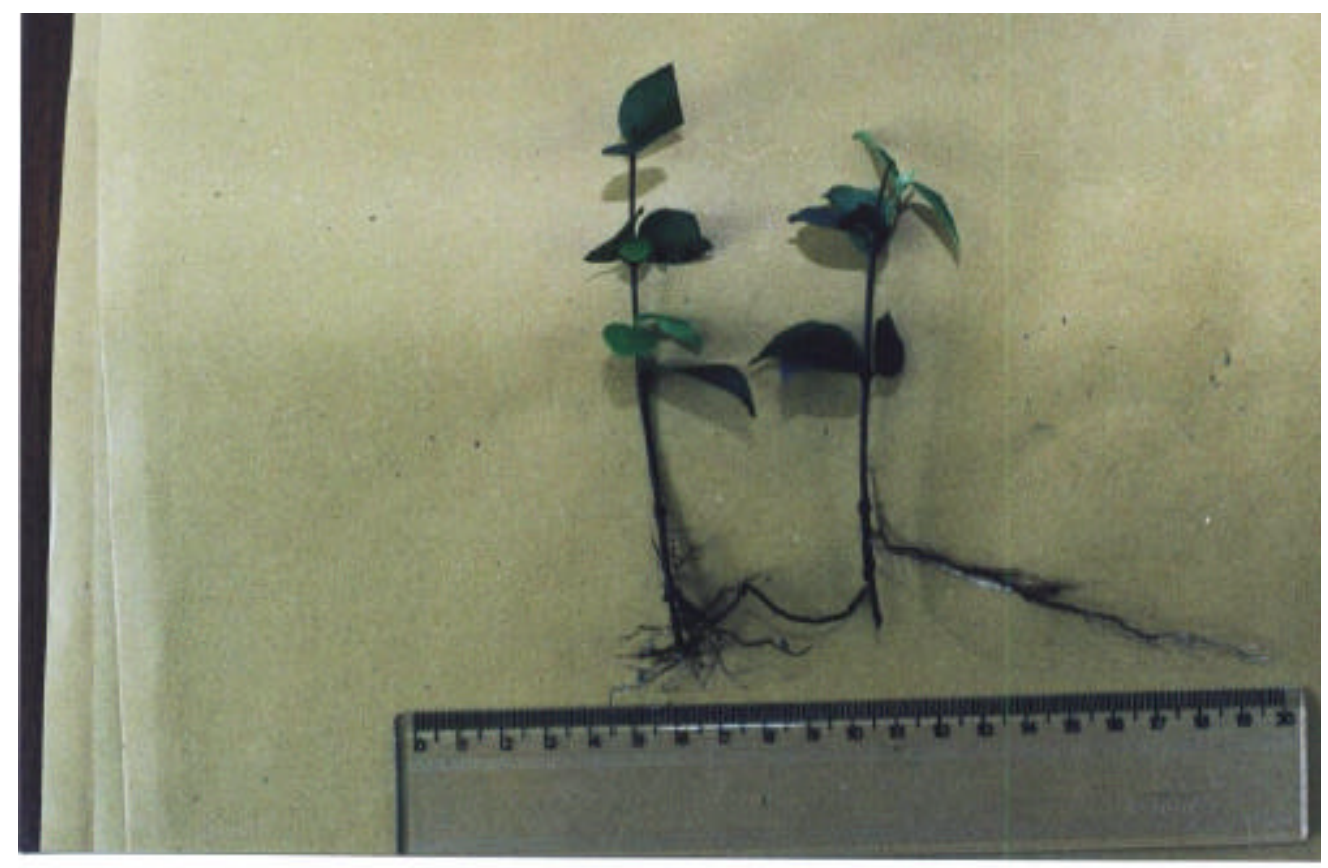

Figura 17 - Estacas apicais de Jabuticabeira com $4000 \mathrm{mg}^{-\mathrm{L}^{-1}}$ de AIB, no substrato areia grossa e pH 4.5 aos 180 dias, mostrando a formação da raiz adventícia 


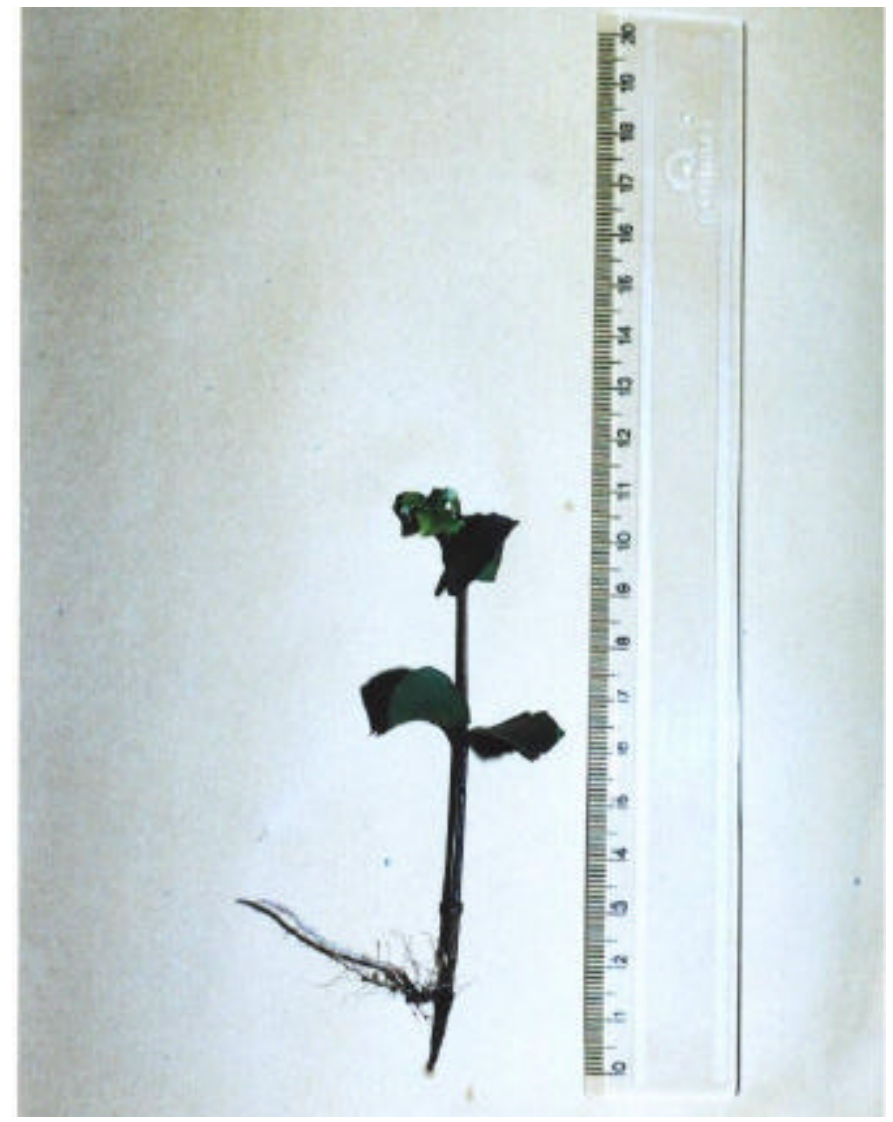

Figura 18 - Estaca apical de Jabuticabeira com 2000 $\mathrm{mg} . \mathrm{L}^{-1}$ de AIB, no substrato areia grossa e $\mathrm{pH} 4.5$ aos 180 dias, mostrando a formação de raízes adventícias na base da estaca

As raízes das estacas apresentadas na figura 20, substrato vermiculita com pH 5.5, quando comparadas com as raízes da estaca submetida ao mesmo substrato, mas com valores $\mathrm{pH} 4.5$ (Figura 19), apresentam maior vigor. Indicando provavelmente uma influência do pH na absorção de AIB. 


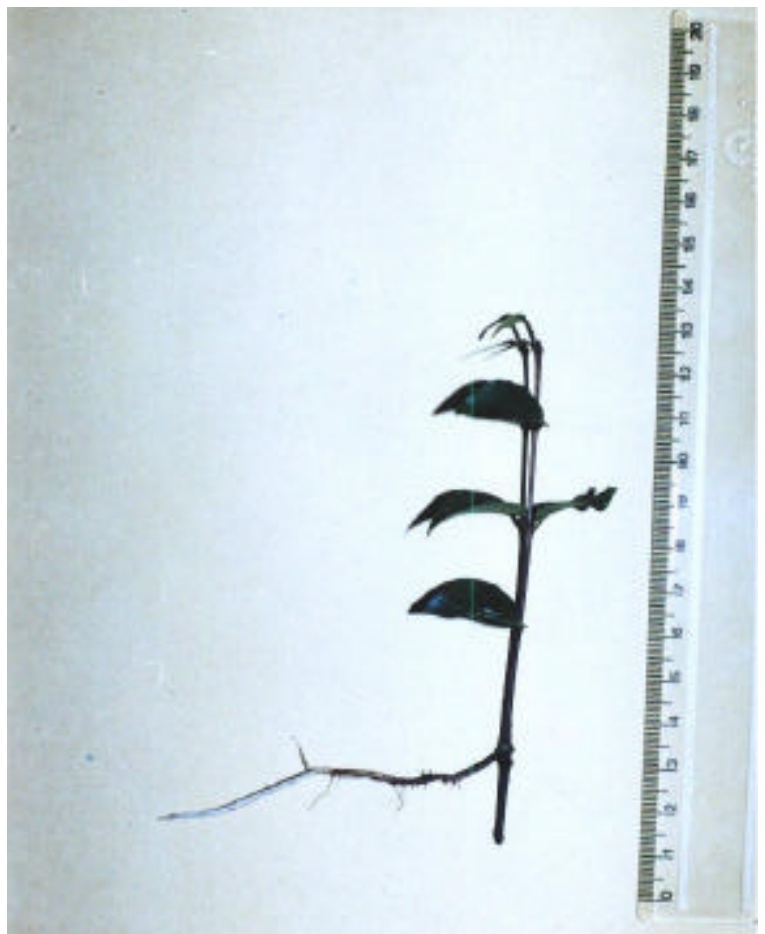

Figura 19 - Estacas apicais de com $2000 \mathrm{mg} \cdot \mathrm{L}^{-1}$ de AIB, no substrato vermiculita e pH 4.5 aos 180 dias

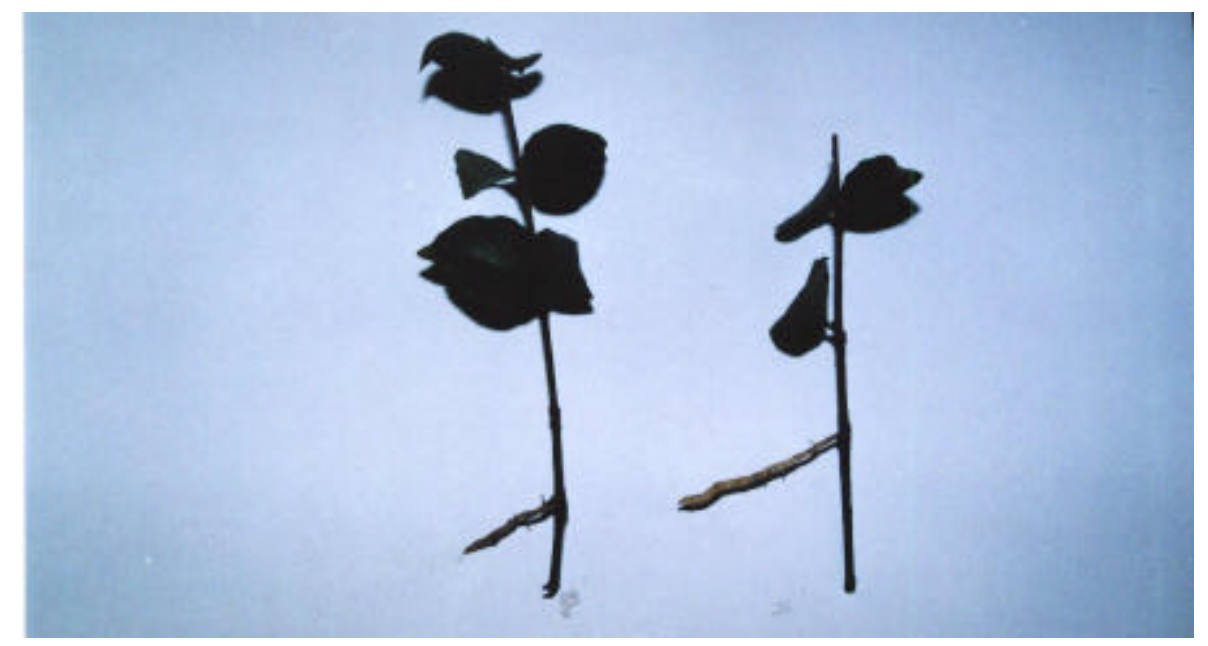

Figura 20 - Estacas apicais de Jabuticabeira com $4000 \mathrm{mg} \cdot \mathrm{L}^{-1}$ de AIB, no substrato vermiculita e pH 5.5 aos 180 dias, mostrando raízes adventícias vigorosas 


\subsection{Conclusão}

Os resultados obtidos, nas condições deste experimento, permitem estabelecer as seguintes conclusões:

O melhor substrato para enraizamento de estacas apicais de jabuticabeira (Myrciaria jaboticaba(Vell.) Berg) foi areia grossa.

O processo de enraizamento nas estacas apicais seguiu uma tendência polinomial de ordem 2 .

A utilização de ácido indolbutírico (AIB) não influenciou no enraizamento das estacas.

Os valores de $\mathrm{pH} 4.5$ e 5.5 quando interagiram com o substrato areia grossa, estimularam a formação de raízes na base das estacas apicais.

Valores elevados (maior que 5.5) e baixos (menor que 3.5) de $\mathrm{pH}$ estimulam reações que inibem a formação de raízes em estacas apicais. 


\section{CARACTERIZAÇÃO MORFOLÓGICA E MOLECULAR DE ESPÉCIES DE JABUTICABERA (Myrciaria spp).}

\subsection{Introdução}

Segundo Mattos (1983) as jabuticabeiras, sempre foram pouco estudadas, sob o ponto de vista taxonômico. Muita confusão existe no que diz respeito aos nomes vulgares dados aos seus frutos. Muitas vezes, um nome vulgar é aplicado æ̀s espécies e até mesmo gêneros diferentes, dependendo da região onde são encontrados. Nesse sentido as brotações vegetativas desempenham um papel importante na identificação das plantas, podendo ocorrer em várias épocas do ano, mas aquelas que aparecem no final do inverno e início da primavera são as mais intensas. A nova folhagem aparece na periferia das plantas sendo que a cor varia do verde claro ao arroxeado, de acordo com a espécie (DONADIO, 2000), sendo esta característica usada como parâmetro para identificar esta espécie.

As flores da jabuticabeira têm como característica a grande produção de pólen. No momento da antese floral o estigma está receptivo. A autopolinização e a polinização cruzada podem ocorrer com grande freqüência. A taxa de polinização cruzada pode ser alta, graças à quantidade de insetos que visitam as flores desta frutífera (DUARTE, 1997).

Com respeito ao fruto da jabuticabeira o seu amadurecimento ocorre de 3 a 4 semanas após o florescimento. Quanto ao número de colheitas anuais, existem vários fatores que podem influenciar esta característica. Normalmente a maior disponibilidade de água, acarreta um maior número de safras durante um ano. A floração e frutificação podem ocorrer de forma continuada. $O$ aparecimento de frutos pode ocorrer desde as raízes, troncos, ramos e até mesmo em ramos delgados. 
Por se conhecer pouco a biologia da jabuticabeira, principalmente sobre sua variabilidade genética, a avaliação da diversidade através desta característica, pode significar uma tentativa de se conhecer um pouco mais desta espécie e orientar sua preservação e auxiliar nas dúvidas quanto a sua identificação taxonômica.

Segundo DONADIO (2000) o risco de perda de material genético de jabuticabeira é bastante grande, sendo que bancos de germoplasma se restringem a pequenas coleções de plantas em alguns órgãos de pesquisa.

A identificação de espécies e variedades tem se baseado tradicionalmente na descrição de características morfológicas (externa e interna) das plantas. Sem dúvida, essa descrição é mais restrita, sendo necessário algumas vezes o uso de condições controladas para minimizar a variabilidade natural. Um grande avanço foi o desenvolvimento de técnicas genéticas baseadas em exames de DNA.

Atualmente, com o uso de técnicas eficientes para examinar segmentos de DNA, métodos estatísticos para avaliar os dados obtidos e programas de computadores eficientes, o estudo de identificação genética de indivíduos e populações chegou a um bom estágio.

Segundo Sunnucks (2000), organismos individuais diferem nas suas seqüências de DNA, sendo que essa variação pode ser considerada a nível de genes individuais (gênico) ou genótipos (genotípico). A variação genética que ocorre no tempo e no espaço é influenciada pela biologia e as relações que o indivíduo tem com o meio, influenciando na sua estratégia de sobrevivência. Medindo a variação genética e aplicando modelos genéticos de populações podemos inferir sobre a biologia de organismos. Os processos que afetam os indivíduos, afetam a população, influenciando na especiação e interferindo na hierarquia taxonômica. 
Segundo o mesmo autor, a escolha adequada da técnica para análisegenética é vital para o sucesso no estudo de identificação molecular do indivíduo. Para esse estudo podem ser usadas as séries genotípicas para estudo de lóculos múltiplos, sendo pouco precisos, visualizam muitos genes anômalos ao mesmo tempo, mas são tecnicamente convenientes. A variação gênica é usada para estudo de lóculos únicos (simples), produzem dados mais consistentes para uma análise mais precisa, promovendo mais comparabilidade. A grande utilidade de técnicas moleculares permite observar diferenças com grande nível de resolução, encontrando diferenças que seriam idênticas quando se utilizam características fenotípicas. Estas diferenças são obtidas independentemente da parte estudada ou das condições em que a planta foi cultivada. Para poder observar as diferenças do DNA dos seres vivos é necessário um conjunto de técnicas apropriadas. Daquelas existentes, a reação da polimerase em cadeia (PCR) e suas variantes são as mais importantes.

Segundo Ferreira \& Grattapaglia (1995), independentemente do nome utilizado e das pequenas variações na metodologia, a técnica de PCR utilizando "primers" de seqüência arbitrária abriu uma perspectiva inteiramente nova para a análise genômica de indivíduos e populações. Além de facilitar e acelerar os estudos que já ocorriam com as espécies mais tradicionais (ex. milho, tomate, arroz) a tecnologia RAPD trouxe uma verdadeira "democratização" da análise de polimorfismo molecular, ao permitir a realização de estudos de análise genética em espécies anteriormente não contempladas. Desde sua descrição, o uso de marcadores RAPD na análise genética e no melhoramento de plantas tem tido uma difusão extremamente rápida. As aplicações incluem: obtenção de "fingerprints" genômicos de indivíduos, variedades e populações, análise da estrutura e diversidade genética em populações naturais, populações de melhoramento e bancos de germoplasma, estabelecimento de relações filogenéticas entre diferentes acessos, construção de mapas genéticos de alta 
cobertura genômica e a localização de genes de interesse econômico (WILLIAMS et al., 1993).

Para que haja amplificação de um fragmento RAPD no genoma analisado, são necessárias duas seqüências complementares ao "primer" arbitrário e estas devem estar suficientemente adjacentes (< 4000 pares de bases) e em orientação oposta, de maneira a permitir a amplificação exponencial de um segmento de DNA pela DNA polimerase (FERREIRA \& GRATTAPAGLIA, 1995). Em seguida, os segmentos amplificados podem ser visualizados sob luz ultravioleta (devido a grande quantidade de DNA produzido) diretamente na forma de uma banda em um gel de eletroforese, geramente de agarose corado com brometo de etídio. Cada "primer" arbitrário utilizado dirige a síntese de vários segmentos de DNA simultaneamente em diverso pontos do genoma, resultando em várias bandas no gel.

Diante do exposto, e numa tentativa de contribuir para a solução do problema de identificação de jabuticabeiras, o presente trabalho tem por objetivo identificar espécies de jabuticabeiras usando técnicas de marcadores morfológicos (anatomia e morfologia) bem como marcadores moleculares. Esperando-se assim, conhecer um pouco mais sobre essa frutífera.

\subsection{Material e Métodos}

\subsubsection{Análise Morfológica}

O material vegetativo (folhas e ramos) para ser usado na caracterização, anatômica e orgamográfica, foi obtido de plantas dos pomares de jabuticabeiras do Departamento de Produção Vegetal da Escola Superior de Agricultura "Luiz de Queiroz", em Piracicaba-SP do pomar do setor de horticultura da FAFRAM (Faculdade "Dr. Francisco Maeda"). A coleta foi realizada no mês de novembro 
de 2002. Segundo $\operatorname{SIMÃO}^{5}$, as plantas do pomar da ESALQ, usadas como matrizes estavam com aproximadamente 40 anos de idade.

Durante a coleta dos ramos para análise anatômica, foi padronizada a altura de 2,8 metros a partir do solo. As folhas apresentaram-se totalmente expandidas e maduras, com coloração verde escuro, e de todos os exemplares coletados foram escolhidos os ramos que estavam voltados para a face oeste.

Todos os ramos coletados tinham $10 \mathrm{~cm}$ de diâmetro. Após a coleta, os ramos, por serem lenhosos, foram levados para o Laboratório de Tecnologia de Madeira do Departamento de Ciências Florestais da ESALQ, para a realização dos cortes anatômicos.

Após a realização dos cortes, nos materiais a fresco, os mesmos foram clarificados com hipoclorito de sódio à $20 \%$ por um período de 30 min utos, e lavados em água destilada por várias vezes até não exalarem mais cheiro do produto. Estes materiais foram colocados, por um a três minutos em corante verde iodo diluído a 1\% em água e, em seguida procedeurse a lavagem em água destilada (5 vezes). A seguir foram colocados em corante para celulose e novamente lavados por cinco vezes.

Após a montagem, com gelatina glicerinada, as lâminas foram observadas no microscópio e as imagens analisadas e fotomicrografadas.

\subsubsection{Coleta do Material para Identificação Botânica}

Para a realização da coleta do material botânico usado na identificação das espécies de jabuticaba, utilizou-se do procedimento recomendado pelo Instituto de Botânica de São Paulo (Série Documentos, 1989).

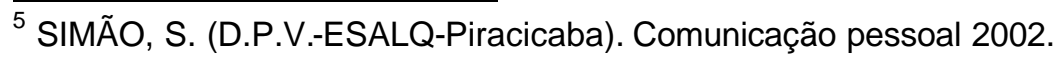


Assim, a coleta dos ramos férteis da planta foi efetuada, a uma altura de 2,5 metros do nível do solo nos ramos terminais, sempre nas faces leste e oeste.

Devido a sua natureza bastante tênue, as flores da jabuticabeira foram conservadas em líquido de Hammarlund (sulfato de cobre em solução saturada + formol a $40 \%$ = formalina + água destilada na proporção de 3:0,1:1). Os frutos presentes em algumas plantas foram coletados e conservados em solução de sulfato de cobre em solução aquosa a $5 \%$, ácido sulfuroso em solução aquosa a 5-6\% e glicerina (método de Drummond).

Para cada material coletado, preencheu-se uma ficha, constando dados adicionais como textura da casca, porte da planta, tamanho do pedúnculo e do fruto, etc, segundo orientação do Conselho Nacional de Desenvolvimento Científico e Tecnológico, informações estas posteriormente transcritas para uma ficha de herbário.

O modelo da ficha é apresentado em seguida:

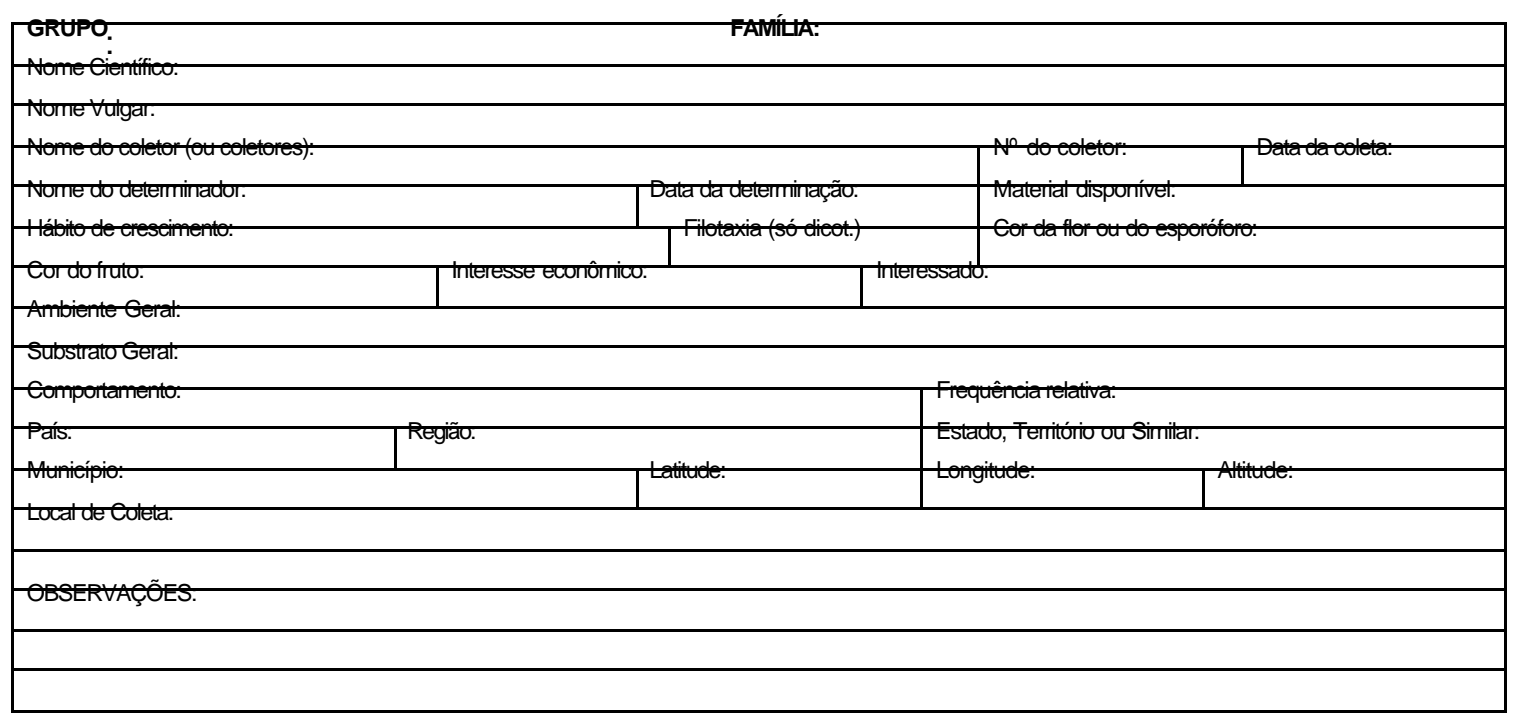



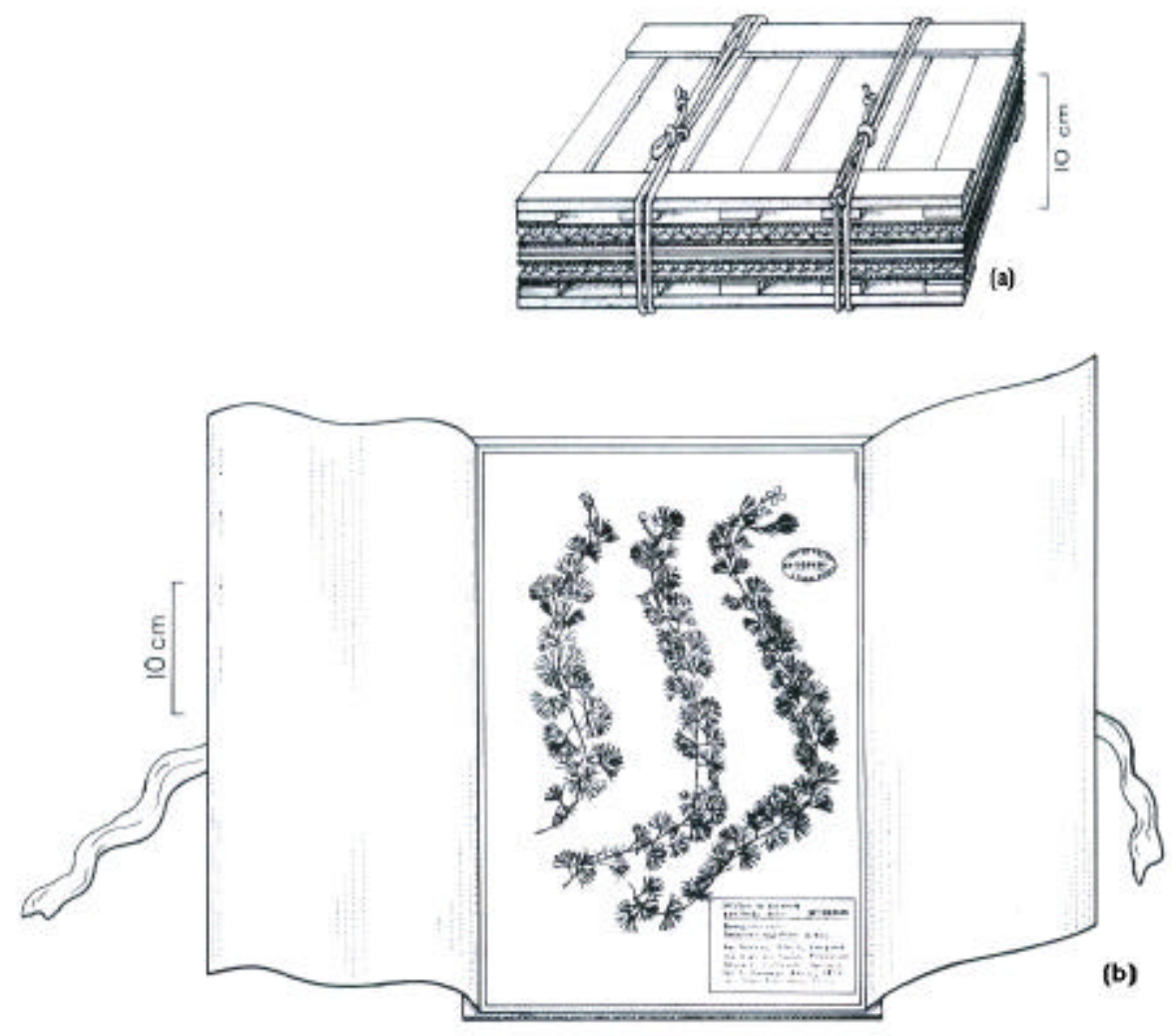

Figura 21 - (a) Prensa, (b) Exsicata

Após a secagem das flores, em papel absorvente, foram prensadas e desidratadas em estufa do Laboratório de Botânica da Faculdade "Dr. Francisco Maeda" (FAFRAM). A montagem das exsicatas, foi feita colocando-se as flores em saco de papel e a etiqueta colocada no canto inferior direito da cartolina de montagem. No canto superior esquerdo, diametralmente oposto, foi fixado o envelope para conter as partes eventualmente despencadas do material, tanto caídas durante o processo de secagem na estufa, como daquelas necessariamente retiradas para o estudo do vegetal.

O material coletado foi identificado com códigos: 
- Os materiais do pomar do Setor de Horticultura do Departamento de Produção Vegetal da ESALQ-USP:

○ Códigos: Pira1, Pira2, Pira3, E01, E02, E03, E04, P01 e P02.

- Os materiais coletados do pomar do Departamento de Produção Vegetal da ESALQ-USP, localizado no Setor de Engenharia:

- Códigos: P1A, P2A, P3A, P4A, P5A, P6A, P7A, P8A, P9A, e P10A.

- Os materiais coletados do Setor de Fruticultura da Faculdade "Dr. Francisco Maeda" de Ituverava-SP:

○ Códigos: 1I, 2I, 3I, 4I, 5I, 6I, 7I, 8I, 9l, 10I, 11l e 12 I.

\subsubsection{Revisão de Herbários}

Considerando-se sua localização e sua relação com as principais regiões de ocorrência, das espécies de jabuticabeiras cultivadas, as exsicatas do material coletado, foram comparadas com outros espécimes do acervo de herbários escolhidos e literatura especializada.

Os herbários selecionados para a análise das exsicatas encontram-se descritos na Tabela 3. 
Tabela 3 . Herbários usados para revisão do material botânico

\begin{tabular}{|c|c|c|c|c|}
\hline Estado & Cidade & Sigla & Tnstituiçao & Curador(a) \\
\hline SP & São Paulo & SP & $\begin{array}{l}\text { Instituto de Botânica de São Paulo-Secretaria de } \\
\text { Estado do Meio Ambiente }\end{array}$ & $\mathrm{Dr}^{\mathrm{a}}$ Inês Cordeiro \\
\hline SP & São Paulo & SPB/SPF & Instituto de Biociências - Universidade de São Paulo & $\begin{array}{l}\text { Dr. José Rubens } \\
\text { Pirani }\end{array}$ \\
\hline SP & Campinas & UEC & Universidade de Campinas & $\begin{array}{l}\mathrm{Dr}^{\circ} \text { Washington } \\
\text { Marcondes } \\
\text { Ferreira Neto }\end{array}$ \\
\hline SP & Campinas & IAC & Instituto Agronômico de Campinas & $\begin{array}{l}\mathrm{Dr}^{\mathrm{a}} \text { Sigrid Jung } \\
\text { Mendaçolli }\end{array}$ \\
\hline SP & Rio Claro & HRCB & UNESP-Rio Claro & $\begin{array}{l}\text { Dr. Marco Antônio } \\
\text { Assis }\end{array}$ \\
\hline SP & Piracicaba & ESA & ESALQ-USP/Piracicaba & $\begin{array}{l}\text { Dr. Lindolfo } \\
\text { Capellari Júnior }\end{array}$ \\
\hline SP & Ituverava & FAFRAM & Faculdade "Dr. Francisco Maeda" & $\begin{array}{l}\text { M.Sc.Márcio } \\
\text { Pereira }\end{array}$ \\
\hline MG & Uberlândia & UFU & Universidade Federal de Uberlândia & $\begin{array}{l}\text { Dro Jimi Nacki } \\
\text { Nakagima }\end{array}$ \\
\hline MG & Belo Horizonte & UPMG & Universidade Federal de Minas Gerais & Dr. Júlio Lombardi \\
\hline
\end{tabular}

\subsubsection{Caracterização Molecular}

Das mesmas plantas, onde se coletou o material vegetativo para análise morfológica, foram coletadas folhas de brotações novas (não totalmente expandidas), o que resultou em, aproximadamente, $180 \mathrm{mg}$ de tecido fresco. Este material foi colocado em pequenos sacos de papel, devidamente identificados com o código das plantas e armazenados em tambor com nitrogênio líquido a 86ํㅡ e, em seguida transportado até o laboratório de Genética de Bactérias do Departamento de Biologia Aplicada à agropecuária da UNESP/FCAV para extração do DNA. 


\subsubsection{Extração de DNA de tecido vegetal}

A extração de DNA das folhas das jabuticabeiras seguiu, a princípio, a metodologia descrita em Lodhi (1994), modificado pela equipe do Laboratório de Biologia Aplicada à Agricultura da UNESP/FCAV de Jaboticabal, de acordo com o seguinte procedimento:

- Triturourse 0,1g de folhas jovens (não totalmente expandidas) na presença de nitrogênio líquido, completando-se o processo após adicionar $1 \mathrm{~mL}$ do tampão de extração, deixando o material bem fino. O material foi transferido para tubos de microcentrífuga de $2 \mathrm{~mL}$, acrescentando-se 0,01 g de PVP (polyvinylpolypirrolidine) (Sigma, P6755), invertendo-se os tubos ocasionalmente, para melhor homogeneização. Após incubação a $60^{\circ} \mathrm{C}$ por 25 minutos e esfriamento até atingir a temperatura ambiente, adicionou-se 1 $\mathrm{ml}$ de clorofórmio/álcool isoamílico (24:1), agitando-se levemente os tubos. $O$ processo de centrifugação foi realizado a temperatura ambiente com velocidade de $10621 \mathrm{xg}$ por 15 minutos. A parte aquosa foi transferida para novos tubos de 2.0 $\mathrm{mL}$. Na seqüência, adicionou-se 0,5 volume de $\mathrm{NaCl} 5 \mathrm{M}$ e dois volumes de etanol gelado. A solução foi armazenada a $-80^{\circ} \mathrm{C}$ por 20 minutos, para total precipitação do DNA e depois centrifugada à $4.460 \mathrm{xg}$ por 5 minutos e em seguida centrifugado a $10.621 \mathrm{xg}$ por mais 5 minutos a 4 $\mathrm{C}$ para formação do "pellet" (precipitado). O sobrenadante foi descartado e o precipitado, lavado com etanol $76 \%$ (quantidade suficiente para cobrir o "pellet"), centrifugando
a $10.621 \mathrm{xg}$ por 5 minutos a $4^{\circ} \mathrm{C}$. Por fim, removeutse o etanol e deixou o "pellet" de DNA secar, deixando os tubos invertidos 
por 20minutos. Logo em seguida, o precipitado foi dissolvido $100 \mu \mathrm{L}$ de solução de TE (Tris $10 \mathrm{mM}$, EDTA $1 \mathrm{mM}, \mathrm{pH}$ 8,0), colocando-se $10 \mu \mathrm{L}$ de RNAse à concentração de $10 \mathrm{mg} / \mathrm{mL}$ e incubado a $37^{\circ} \mathrm{C}$ por 30 minutos Dessa maneira, o material ficou pronto para ser quantificado.

\subsection{Reagentes}

1- Tampão de Extração: $20 \mathrm{mM}$ EDTA + 100mM Tris-HCl. Ajustar pH para 8.0, com $\mathrm{HCl}$ e adicionar $\mathrm{NaCl} 1,4 \mathrm{M}$ e $2 \%$ (v/v) de CTAB. Dissolver o CTAB a $60^{\circ} \mathrm{C}$. Armazenar a $37^{\circ} \mathrm{C}$. Adicionar $0,2 \%$ de Bmercaptoetanol quando for usar.

2- Clorofórmio/álcool isoamílico (24:1) (v/v).

3- $\mathrm{NaCl} 5 \mathrm{M}$.

4- Tampão TE: Tris-HCl 10mM + EDTA 1mM. Ajustar pH para 8.0 e a utoclavar. 5- RNAse (Sigma R9009: 10mg/mL).

\subsubsection{Quantificação e verificação da qualidade do DNA genômico}

As amostras foram quantificadas em espectofotômetro DU 640B (Beckman), diluídas na proporção de $2 \mu \mathrm{L}$ da solução estoque de DNA em 98 $\mu \mathrm{L}$ de TE $10: 1(\mathrm{v} / \mathrm{V})$.

A quantificação por espectrofotometria permite estimar a pureza do DNA pela razão entre leituras feitas a 260 e $280 \mathrm{~nm}$. Preparações puras de DNA têm valores para este coeficiente no intervalo de 1.8 a 2.0. Valores abaixo de 1.8 indicam contaminação do ácido nucléico com proteína. Para estimar a 
quantidade de DNA total obtido foi utilizado o padrão em que uma unidade de absorbância a $260 \mathrm{~nm}$ equivale a $50 \mu \mathrm{g}$ de DNA por $\mathrm{mL}$ de solução. A concentração final usada como solução de trabalho foi de $10 \mathrm{ng} \cdot \mu \mathrm{L}^{-1}$, necessária para as reações de RAPD.

Para análise da qualidade do DNA extraído foram feitas corridas em géis de agarose $0,8 \%$, onde foram aplicados $10 \mu \mathrm{L}$ de DNA das amostras e $3 \mu \mathrm{L}$ de tampão de carregamento (Tris - HCL $0,1 \mathrm{M}, \mathrm{pH}$ 6.8; azul de bromofenol $0,02 \%$; glicerol 50\%). Para comparação do padrão das bandas foram usados $8 \mu \mathrm{L}$ de "1Kb Plus DNA Ladder" da GIBCO/BRL. O tampão usado no preparo do gel e corrida foi o Tris-Borato-EDTA $1 X$ (Tris $89 \mathrm{mM} ; \mathrm{H}_{\mathrm{B}} \mathrm{BO}_{3} \mathrm{mM}$; EDTA 2,5 mM, pH 8.2) contendo $0,5 \mu \mathrm{g} \cdot \mathrm{mL}^{-1}$ de brometo de etídio. O tempo de corrida eletroforética foi de aproximadamente $2 \mathrm{~h}$ em tensão de $48 \mathrm{~V}$. Os fragmentos de DNA genômico foram visualizados sob luz UV e documentados em um fotodocumentador modelo GEL DOC 2000 (BIO RAD).

\subsubsection{Amplificação do DNA por PCR}

As amostras de DNA foram amplificadas no Laboratório de Genética de Bactérias do Departamento de Biologia Aplicada à Agropecuária da FCAV/UNESP - Jaboticabal.

O procedimento para reações de amplificações do DNA, bem como a análise de PCR com oligonucleotídeos iniciadores adotados, foi o mesmo descrito por Willians et al. (1990). Os oligonucleotídeos iniciadores ("primers") utilizados neste trabalho foram provenientes da coleção da University of British Colômbia - Nucleic Acid - Protein Service Unit (Canadá), cujos números de acesso à coleção, bem como as respectivas seqüências, encontram -se descritas a seguir: 
Tabela 4 . Seqüências arbitrárias dos iniciadores utilizados e respectivos números de acessos

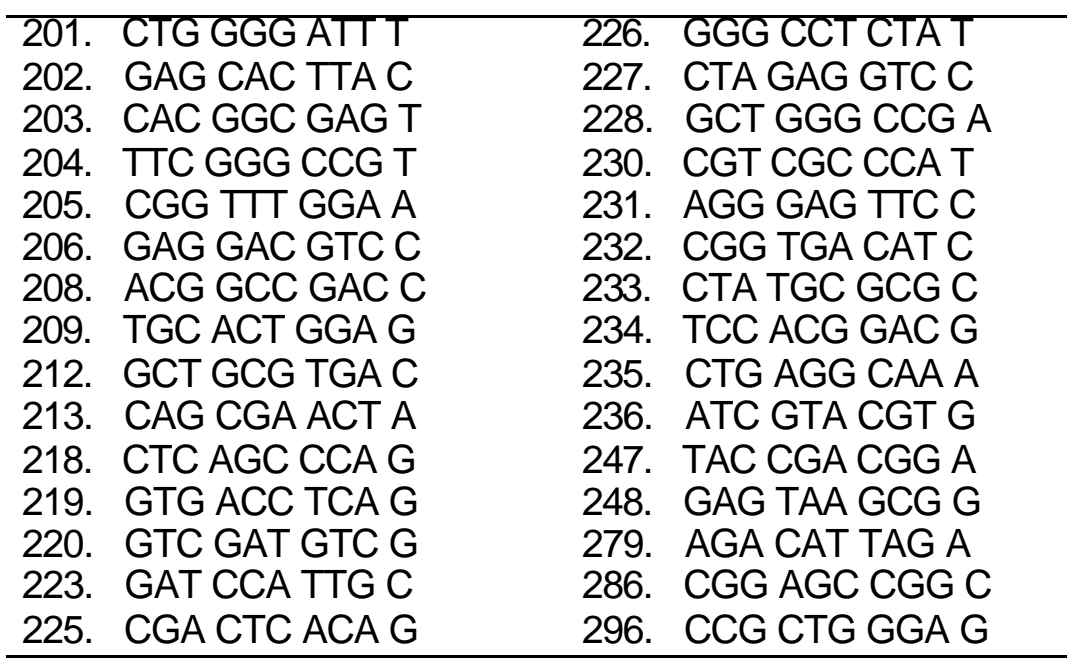

As reações de amplificação foram conduzidas em um volume de reação de $20 \mu \mathrm{L}$ contendo: $30 \mathrm{ng}$ do DNA a ser amplificado; solução de dNTPs $2.0 \mathrm{mM}$; $1 \mathrm{mM} \mathrm{MgCl}$; solução tampão (1X); $15 \mathrm{ng}$ de cada um dos iniciadores; 1,0 U Taq DNA polimerase e água destilada grau Milli Q (esterilizada previamente).

As reações de amplificação foram realizadas usando-se um aparelho termociclador marca MJ Research, modelo PTC 100, equipado com circuito "Hot Bonnet". O programa adotado para esta etapa de análise foi montado como se descreve: 4 minutos a $92^{\circ} \mathrm{C}$ e, depois foram realizados 48 ciclos de 1 minuto a $92^{\circ} \mathrm{C} ; 1$ minuto e 30 segundos a $37^{\circ} \mathrm{C} ; 1$ minuto e 30 segundos a $72^{\circ}$ C; e, no final, 5 minutos a $72^{\circ} \mathrm{C}$.

As amostras amplificadas foram analisadas em gel de agarose $1,5 \%(\mathrm{p} / \mathrm{p})$, utilizando o tampão de corrida TEB 1X (89 mM de Tris; 2,5 mM de EDTA e 89 $\mathrm{mM}$ de Ácido Bórico, $\mathrm{pH}$ 8.3) contendo $0,5 \mu \mathrm{g} / \mathrm{L}$ de brometo de etídio.

Os fragmentos amplificados pela PCR e separados por eletroforese foram comparados com aqueles do DNA de peso molecular conhecido ("1 Kb ladder") 
e foi constatada a ausência ou a presença da migração eletroforética dos mesmos bem como suas distâncias.

\subsubsection{Análise estatística}

Por meio da análise do bandeamento produzido para cada iniciador polimórfico, foi conferido o parâmetro 1 (um) para a presença de banda e 0 (zero) para a ausência de banda, permitindo a elaboração de uma matriz binária.

Os géis foram normalizados com base na referência do tamanho normal. A porcentagem de similaridade entre padrões foi calculada usando o Dice (coeficiente de correlação), segundo a seguinte fórmula (HOOKEY et al., 1999).

$$
S D=\frac{2 n_{A B}}{n_{A}+n_{B}}
$$

Onde, п п bandas em $A$ e $\mathbf{n}_{\mathbf{B}}$ é o número total de bandas em $B$. $O$ dendrograma foi construído pelo método UPGMA "unweighted pair group method with arithmetic averages", através do programa SAHN do NTSYS (Numerical Taxonomy and Multivariate Analysis System) (ROHLF \& SLICE, 1992, ), que fez a comparação dos acessos agrupando-os de forma tanto mais similar quanto mais coincidentes forem os fragmentos de mesmo peso molecular. 


\subsection{Resultados e Discussão}

\subsubsection{Caracterização Morfológica}

Por meio da comparação dos exemplares coletados, tanto com a descrição da bibliografia especializada, MATTOS (1983), como dos espécimes conservados nos herbários visitados, foi possível agrupar as plantas estudadas em quatro espécies, permitindo verificar que realmente as espécies de jabuticabeiras do ponto de vista taxonômico, são pouco estudadas, pois de todas as coleções consultadas, foram encontradas apenas exsicatas de duas espécies, Myrciaria jaboticaba e Myrciaria cauliflora, sendo inexistentes exsicatas das demais espécies $M$. coronata, $M$. phitrantha, $M$. piruviana, $M$. oblongata, M. spiritosantensis, M. grandiflora e M. aureana) nos herbários visitados.

Através desse levantamento, pode ser constatado também que as coleções apresentam vasto material do gênero Myrciaria, porém as espécies de Jabuticabeiras descritas estão restritas a 2 grupos nos herbários do estado de São Paulo (Tabela 5), mostrando que outras ferramentas devem ser usadas para auxiliar na identificação dessas espécies. 
Tabela 5 . Relação das espécies do gênero Myrciaria encontradas nos herbários visitados

\begin{tabular}{|c|c|c|c|c|c|c|c|c|}
\hline Espécie & Herbário & Data coleta & País & Estado & Cidade & Procedência & Determinador & Data \\
\hline Myrciaria aureana Mattos & SPF 83006 & $15 / 01 / 64$ & Brasil & SP & SP & Água Funda SP & J. Mattos & $15 / 01 / 64$ \\
\hline Myrciaria cauliflora (Mart.) O. Berg & SP 105906 & 03/10/67 & Brasil & SP & Campinas & Faz.Sta.Eliza & J. Mattor & 1968 \\
\hline Myrciaria cauliflora (Mart.) O. Berg & SP 184524 & $07 / 09 / 80$ & Brasil & MG & Centro do Riacho & Serra do Cipó & M.L.Kawascki & $13 / 03 / 85$ \\
\hline Myrciaria cauliflora (Mart.) O. Berg & SP 48652 & $20 / 09 / 40$ & Brasil & SP & Ubatuba & Est. Experim. & J. Mattos & $11 / 1968$ \\
\hline Myrciaria cauliflora (Mart.) O. Berg & SP 28997 & $30 / 09 / 31$ & Brasil & SP & Vila Cerqueira & - & J. Mattos & $11 / 1968$ \\
\hline Myrciaria cauliflora (Mart.) O. Berg & SP 41755 & $23 / 11 / 39$ & Brasil & SP & S. Brito & Capital & J. Mattos & $11 / 1968$ \\
\hline Myrciaria cauliflora (Mart.) O. Berg & SP 26804 & $30 / 09 / 06$ & Brasil & SP & S. Brito & Capital & J. Mattos & $03 / 1968$ \\
\hline Myrciaria cauliflora (Mart.) O. Berg & SP 105905 & $19 / 01 / 83$ & Brasil & SP & S. Brito & Capital & J. Mattos & $11 / 1968$ \\
\hline Myrciaria cauliflora (Mart.) O. Berg & SP 249185 & $07 / 12 / 88$ & Bolívia & Santa Cruz & Andréa Ibñez & $12 \mathrm{Km}$ de Sta.Cruz & M.L.Kawascki & 1991 \\
\hline Myrciaria cauliflora (Mart.) O. Berg & SP 50184 & $24 / 08 / 45$ & Brasil & SP & Monte Alegre & Amparo & J. Mattos & $11 / 1968$ \\
\hline Myrciaria cauliflora (Mart.) O. Berg & SP 292512 & $23 / 10 / 87$ & Brasil & SP & Piracicaba & - & - & - \\
\hline Myrciaria cauliflora (Mart.) O. Berg & SP 348592 & $24 / 09 / 85$ & Brasil & MG & Juiz de Fora & Cedofeita & L. Krigen & $24 / 09 / 85$ \\
\hline Myrciaria cauliflora (Mart.) O. Berg & SPF 19517 & $12 / 12 / 89$ & Brasil & SP & SP & Conc.do Matto BH & M.L.Kawascki & 32854 \\
\hline Myrciaria cauliflora (Mart.) O. Berg & SPF 37295 & 07/09/80 & Brasil & SP & SP & Sant.do Riacho MG & M.L.Kawascki & $07 / 09 / 80$ \\
\hline Myrciaria cauliflora (Mart.) O. Berg & IAC 30233 & $17 / 03 / 95$ & Brasil & SP & SP & Monte Alegre do Sul & M.L.Kawascki & $17 / 03 / 95$ \\
\hline Myrciaria cauliflora (Mart.) O. Berg & UEC 062642 & $29 / 09 / 90$ & Brasil & SP & SP & Campinas SP & $\begin{array}{l}\text { L.C.Bernarci } \\
\text { Marcelo Augusto Evert }\end{array}$ & $29 / 09 / 90$ \\
\hline Myrciaria cauliflora (Mart.) O. Berg & ESA 27442 & $21 / 10 / 95$ & Brasil & SP & Piracicaba & & & $21 / 10 / 95$ \\
\hline Myrciaria cauliflora (Mart.) O. Berg & ESA 68671 & 24/09/85 & Brasil & SP & Piracicaba & & $\begin{array}{l}\text { Lkrieger } \\
\text { Renato Goldemberg }\end{array}$ & $24 / 09 / 85$ \\
\hline Myrciaria cauliflora (Mart.) O. Berg & ESA 14400 & 20/10/89 & Brasil & SP & Piracicaba & & $(479)$ & 20/10/89 \\
\hline Myrciaria ciliolata (Cambess.) O. Berg & UFC 11082 & $23 / 05 / 86$ & Brasil & SP & S.J.dos Campos & - & - & - \\
\hline Myrciaria ciliolata (Cambess.) O. Berg & UFC 115122 & 02/04/99 & Brasil & SP & Jundiaí & R.Biol.Municipal & Aguiar, at. & $s / d$ \\
\hline Myrciaria ciliolata (Cambess.) O. Berg & SPSF 10788 & $14 / 01 / 87$ & Brasil & SP & Marília & Est. Exper.Inst.Florestal & Osny T. Aguiar & $14 / 01 / 87$ \\
\hline Myrciaria ciliolata (Cambess.) O. Berg & SPSF 12059 & $29 / 03 / 88$ & Brasil & $\mathrm{SP}$ & São Carlos & $\begin{array}{l}\text { Reserva Estadual do Instituto } \\
\text { Florestal }\end{array}$ & Osny T. Aguiar & $29 / 03 / 88$ \\
\hline
\end{tabular}


Tabela 5 . Relação das espécies do gênero Myrciaria encontradas nos herbários visitados

\begin{tabular}{|c|c|c|c|c|c|c|c|c|}
\hline Espécie & Herbário & Data coleta & País & Estado & Cidade & Procedência & Determinador & Data \\
\hline Myrciaria ciliolata (Cambess.) O. Berg & SPSF 13368 & $17 / 02 / 90$ & Brasil & SP & Atibaia & Bairro da Usina & Osny T. Aguiar & 17/02/90 \\
\hline Myrciaria ciliolata (Cambess.) O. Berg & SPSF 4491 & $s / d$ & Brasil & $\mathrm{SP}$ & Serra da Cantareira & Região do Pinheirinho & Osny T. Aguiar & 1980 \\
\hline Myrciaria cuspidata (DC.) O. Berg & UEC 118547 & $13 / 11 / 99$ & Brasil & $\mathrm{SP}$ & SP & Papopema SP & M. Sobral & 13/11/99 \\
\hline Myrciaria cuspidata (DC.) O. Berg & UEC 12196 & $23 / 03 / 68$ & Brasil & $\mathrm{SP}$ & SP & JaguarialvaPR & M. Mattos & 23/03/95 \\
\hline Myrciaria cuspidata Berg & SPSF 12177 & $20 / 05 / 86$ & Brasil & $\mathrm{SP}$ & Balsa & São Luiz do Parumâ & G. Hatschbach & 10/1986 \\
\hline Myrciaria cuspidata DC & FUEL 28265 & $13 / 11 / 99$ & Brasil & SP & Paraná & Sapopome PR & M. Sobral & 13/11/99 \\
\hline Myrciaria cuspidata O. Berg & CESJ 11227 & $18 / 12 / 71$ & Brasil & SP & Juiz de Fora & Vila Velha-PR & M. Sobral & 18/12/71 \\
\hline Myrciaria cuspidata O. Berg & SP 347021 & $30 / 12 / 91$ & Brasil & SP & São Paulo & Abaíra-BA & E.Niclughadha & $30 / 12 / 91$ \\
\hline Myrciaria cuspidata O. Berg & SP 288263 & $14 / 11 / 94$ & Brasil & SP & São Paulo & ItararéSP & & 14/11/94 \\
\hline Myrciaria cuspidata O. Berg & SP 306576 & $06 / 12 / 94$ & Brasil & SP & São Paulo & P.E.M.-Diabo & M.L.Kawascki & $06 / 12 / 94$ \\
\hline Myrciaria cuspidata O. Berg & SPF 40669 & $18 / 01 / 72$ & Brasil & SP & São Paulo & Sapopema & M. Sobral & 18/01/72 \\
\hline Myrciaria cuspidata O. Berg & SPF 90808 & & Brasil & SP & São Paulo & Araíra-BA & & \\
\hline Myrciaria cuspidata O. Berg & IAC 32878 & 09/1985 & Brasil & $\mathrm{SP}$ & São Paulo & Encruzilhada do Sul-RS & M. Sobral & 9/1985 \\
\hline Myrciaria delicatula (DC.) O. Berg. & SP 47403 & 03/1942 & Brasil & $\mathrm{SP}$ & São Paulo & Jardim Botânico & M.L.Kawascki & 03/1942 \\
\hline Myrciaria delicatula (DC.) О. Berg. & SP 339032 & $28 / 01 / 88$ & Brasil & SP & São Paulo & Parque do CarmoSP & M.LKawascki & $28 / 01 / 88$ \\
\hline Myrciaria delicatula (DC.) O. Berg. & SPSF 13900 & 09/10/89 & Brasil & $\mathrm{PR}$ & Ponta Grossa & Rio São Jorge & Osny T. Aguiar & 13/03/95 \\
\hline Myrciaria dubia (H.B.C.) McVaugh & SP 359167 & $24 / 09 / 00$ & Brasil & SP & São Paulo & Conceição Arag. PA & S.S. Almeida & $24 / 09 / 00$ \\
\hline Myrciaria dubia (H.B.C.) McVaugh & SP 80033 & $18 / 08 / 55$ & Brasil & SP & São Paulo & Conceição Arag. PA & M. Sobral & $18 / 08 / 90$ \\
\hline Myrciaria dubia (Kunth) McVaugh & UFC 12299 & $21 / 10 / 77$ & Brasil & PA & Tucucuí & Rio Tocantins & M.Sobral & 2003 \\
\hline Myrciaria dubia (Kunth) McVaugh & UFC 97090 & 28/05/77 & Brasil & MT & - & Rio Juruena & M.Sobral & 2003 \\
\hline Myrciaria dubia (Kunth) McVaugh & UFC 123169 & $15 / 08 / 00$ & Brasil & MT & Gaucha do Norte & Área Urbana & - & - \\
\hline Myrciaria dubia (Kunth) McVaugh & SPF 46225 & 07/10/85 & Brasil & SP & SP & São Felix Arag. MT & M. Sobral & 07/10/85 \\
\hline Myrciaria dubia (Kunth) McVaugh & SP 10486 & $13 / 01 / 68$ & Brasil & $\mathrm{SP}$ & São Paulo & OriximináPA & M. Sobral & 1992 \\
\hline Myrciaria floribunda (Camb.) Legr. & SPSF 8057 & $27 / 04 / 81$ & Brasil & SP & Campos do Jordão & Parque Estadual & Marli P.M.de Lima & \\
\hline Myrciaria floribunda (H.West ex Willd.) O. Berg & SPF 156249 & $13 / 03 / 00$ & Brasil & PA & Barbacena & Caripi & C.S.Rosério & \\
\hline Myrciaria floribunda (H.West ex Willd.) O. Berg & SPF 154004 & 19/10/84 & Brasil & BA & Abaira & Dunas de Itupã & M.Sobral & $198 /$ \\
\hline Myrciaria floribunda (H.West ex Willd.) O. Berg & SPF 153033 & $10 / 12 / 01$ & Brasil & MG & Caratinga & Estação Biológica & M. Sobral & $04 / 2002$ \\
\hline
\end{tabular}


Tabela 5 . Relação das espécies do gênero Myrciaria encontradas nos herbários visitados

\begin{tabular}{|c|c|c|c|c|c|c|c|c|}
\hline Espécie & Herbário & Data coleta & País & Estado & Cidade & Procedência & Determinador & Data \\
\hline Myrciaria floribunda (H.West ex Willd.) O. Berg & SPF 141737 & 08/11/94 & Brasil & AM & Manaus & R.Flo.Ducke & SOUZA, MAD. & $02 / 1977$ \\
\hline Myrciaria floribunda (H.West ex Willd.) O. Berg & SPF 81563 & 02/01/93 & Brasil & AL & Penedo & $\begin{array}{l}\text { Marituba } \\
\text { Reserva Florestal BuckeManaus- }\end{array}$ & M.L.Kawascki & $13 / 03 / 02$ \\
\hline Myrciaria floribunda (H.West ex Willd.) O. Berg & UEC 111476 & 12/1995 & Brasil & SP & SP & Souza & & 12/1995 \\
\hline Myrciaria floribunda (H.West ex Willd.) O. Berg & UEC 32947 & 22/07/02 & Brasil & SP & SP & Butantã SP & J. Mattos & 22/07/02 \\
\hline Myrciaria floribunda (H.West ex Willd.) O. Berg & IAC 19345 & 09/10/02 & Brasil & SP & SP & Itirapina-SP & L. C. Bernacá & 09/10/02 \\
\hline Myrciaria floribunda (H.West ex Willd.) O. Berg & IAC 21602 & 1990 & Brasil & SP & SP & Vale do Ribeira & M. Sobral & 1990 \\
\hline Myrciaria floribunda (H.West ex Willd.) O. Berg & IAC 29386 & $27 / 04 / 94$ & Brasil & SP & SP & Campinas-SP & L. Kawasaky & $27 / 04 / 94$ \\
\hline Myrciaria floribunda (H.West ex Willd.) O. Berg & SP 346077 & $15 / 08 / 00$ & Brasil & SP & São Paulo & Gaucha do NorteMT & M.L.Kawascki & $15 / 08 / 00$ \\
\hline Myrciaria floribunda (H.West ex Willd.) O. Berg & SP 347022 & 07/12/92 & Brasil & SP & São Paulo & Abaíra-BA & E.Niclughadha & 07/12/99 \\
\hline Myrciaria floribunda (H.West ex Willd.) O. Berg & SP 345370 & & Brasil & SP & São Paulo & Jussari-BA & & \\
\hline Myrciaria floribunda (H.West ex Willd.) O. Berg & IAC 20091 & 24/08/68 & Brasil & SP & São Paulo & S. Pedro-SP & H.F.Leitão & $24 / 08 / 68$ \\
\hline Myrciaria floribunda (H.West ex Willd.) O. Berg & IAC 20090 & 24/08/68 & Brasil & SP & São Paulo & S. Pedro-SP & H.F.Leitão & $24 / 08 / 68$ \\
\hline Myrciaria floribunda (H.West ex Willd.) O. Berg & IAC 19863 & $10 / 04 / 68$ & Brasil & SP & São Paulo & M. Mirim-SP & J. Mattos & $10 / 04 / 68$ \\
\hline Myrciaria floribunda (West. Ex Willd) Berg & SPSF 17094 & $11 / 01 / 91$ & Brasil & PR & Antonina & Rio Itaqui & M. Sobral & 1993 \\
\hline Myrciaria floribunda (Willd.) Berg & SPSF 2352 & $26 / 10 / 45$ & Brasil & SP & São Paulo & $\begin{array}{l}\text { Bairro do Tremenbé } \\
\text { Estação Experimental do Instituto }\end{array}$ & J. Mattos & $08 / 1961$ \\
\hline Myrciaria floribunda (Willd.) Berg & SPSF 11376 & $30 / 06 / 87$ & Brasil & SP & Assis & Florestal & Osny T. Aguiar & $30 / 06 / 87$ \\
\hline Myrciaria glanduliflora (Kiaersk) Mattos & SPF 41043 & 05/10/81 & Brasil & SP & SP & Morro do Pilar MG & - & 05/10/81 \\
\hline Myrciaria hatschbachii Mattos & SPF 150434 & 23/03/01 & Brasil & PN & Tunas do Paraná & Parque das Lauráceas & M.Hatshbachii & 2001 \\
\hline Myrciaria jaboticaba (Vell.) O. Berg. & SP 105909 & 03/10/67 & Brasil & $\mathrm{SP}$ & São Paulo & IAC-Campinas-SP & J. Mattos & $03 / 10 / 67$ \\
\hline Myrciaria jaboticaba (Vell.) O. Berg. & SP 105909 & 03/10/67 & Brasil & SP & São Paulo & IAC-Campinas-SP & J. Mattos & $03 / 10 / 67$ \\
\hline Myrciaria pallida O. Berg & SPF 46600 & 09/01/69 & Brasil & SP & São Paulo & Serra da Cantereira & M.Sobral & 1992 \\
\hline Myrciaria rivularis (Camb.) Berg & SPSF 2073 & $10 / 04 / 45$ & Brasil & SP & São Paulo & Horto Florestal & D. Bento J. Pickel & $10 / 1956$ \\
\hline Myrciaria rojasii D. Legrand & SPF 149906 & $10 / 01 / 74$ & Paraguai & Alto Parar & $\begin{array}{l}\text { Hernandária } \\
\text { Serra de }\end{array}$ & $20 \mathrm{Km}$ da cidade & Landrum & 1982 \\
\hline Myrciaria sp & SPSF 4701 & $s / d$ & Brasil & SP & Paranapiacaba & Alto da Serra & Osny T. Aguiar & 1980 \\
\hline Myrciaria sp. & SPSF 7324 & $91 / 1969$ & Brasil & SP & Serra da Cantareira & Região do Pinheirinho & Osny T. Aguiar & 1980 \\
\hline Myrciaria strigipes O. Berg & SPF 89505 & 27/12/92 & Brasil & BA & Abaira & Brejo do Empenho & E.Niclughadha & 1999 \\
\hline
\end{tabular}


Tabela 5 . Relação das espécies do gênero Myrciaria encontradas nos herbários visitados

\begin{tabular}{|c|c|c|c|c|c|c|c|c|}
\hline Espécie & Herbário & Data coleta & País & Estado & Cidade & Procedência & Determinador & Data \\
\hline Myrciaria strigipes $\mathrm{O}$. Berg & SPF 90942 & 24/12/91 & Brasil & BA & Abaira & Cantolés & E.Niclughadha & 1999 \\
\hline Myrciaria tenella (DC.) Berg & SPSF 11301 & $04 / 12 / 86$ & Brasil & SP & Teodoro Sampaio & Parque Estadual do Morro do Diabo & Osny T. Aguiar & $04 / 12 / 86$ \\
\hline Myrciaria tenella (DC.) Berg & SPSF 8831 & 29/11/84 & Brasil & SP & Teodoro Sampaio & Parque Estadual do Morro do Diabo & Osny T. Aguiar & $29 / 11 / 84$ \\
\hline Myrciaria tenella (DC.) Berg & SPSF 11303 & $04 / 12 / 86$ & Brasil & SP & Teodoro Sampaio & Parque Estadual do Morro do Diabo & Osny T. Aguiar & $04 / 12 / 86$ \\
\hline Espécie & Herbário & Data coleta & País & Estado & Cidade & Procedência & Determinador & Data \\
\hline Myrciaria tenella (DC.) Berg & SPSF 12240 & $08 / 12 / 86$ & Brasil & SP & Teodoro Sampaio & Parque Estadual do Morro do Diabo & Osny T. Aguiar & $08 / 12 / 86$ \\
\hline Myrciaria tenella (DC.) O. Berg & SPF 71611 & 07/02/33 & Brasil & SP & São Paulo & Butantã & M.Sobral & 1992 \\
\hline Myrciaria tenella (DC.) O. Berg & SPF 85726 & $\mathrm{~s} / \mathrm{d}$ & Brasil & $\mathrm{SP}$ & São Paulo & J. Botânico SP & J. Mattos & 1961 \\
\hline Myrciaria tenella (DC.) O. Berg & SPF 67299 & $05 / 03 / 64$ & Brasil & SP & Paranapiacaba & Estação Biológica & M.L.Kawascki & 1998 \\
\hline Myrciaria tenella (DC.) O. Berg & SPSF 16291 & $06 / 02 / 92$ & Brasil & PR & Paraná & Rio da Várzea & M.Sobral & 1992 \\
\hline Myrciaria trunciflora O. Berg.(Perwiana) & SP 31006 & $04 / 10 / 33$ & Brasil & $\mathrm{SP}$ & São Paulo & CabreúvaSP & F.C.Hoehne & 04/10/33 \\
\hline Myrciaria trunciflora O. Berg.(Perwiana) & SP 26670 & $05 / 10 / 31$ & Brasil & SP & São Paulo & Parque do Estado-SP & F.C.Hoehne & $05 / 10 / 31$ \\
\hline Myrciaria trunciflora O. Berg.(Perwiana) & SP 15070 & $03 / 10 / 67$ & Brasil & SP & São Paulo & IAC-Campinas-SP & J. Mattos & $03 / 10 / 67$ \\
\hline
\end{tabular}


Das trinta e uma plantas estudadas, o de código Pira1, através de informações do pessoal de campo do Setor de Horticultura do Departamento de Produção Vegetal da ESALQUSP, inicialmente coletado como uma Myrciaria, foi identificado posteriormente com o gênero Psidium, fato interessante que pode justificar a dificuldade e confusão no que diz respeito aos nomes vulgares dados aos frutos das espécies pertencentes ao gênero Myrciaria. Mesmo alguns herbários, trazem nas suas coleções mais antigas de Myrciarias, algumas jabuticabeiras com classificações divergentes, principalmente entre as espécies Myrciaria cauliflora e Myrciaria jaboticaba. Na própria literatura essa confusão pode ser notada. MENDONÇA (2000), em um trabalho feito na coleção de jabuticabeiras pertencente à Universidade Federal de Viçosa de Minas Gerais, classificou a Myrciaria cauliflora (Mart.) O. Berg. como cultivar Açú, e Myrciaria jaboticaba (Vell.) O. Berg como cultivar Sabará; já PIO CORRÊA (1984), no clássico dicionário das plantas úteis do Brasil, classificou Myrciaria jaboticaba (Vell.) O. Berg. como cultivar Açú o cultivar Sabará pertencente a espécie Myrciaria trunciflora Berg. . Ainda na mesma obra a espécie Myrciaria cauliflora (Mart.) O. Berg. (incluída ainda no gênero Eugênia) é tratada como "Jaboticaba comum" ou "verdadeira", tendo como sinônimos jabuticaba de Sabará ou jabuticaba de São Paulo.

Na Tabela 6 abaixo, são apresentados as 31 plantas estudadas e suas respectivas identificações, realizadas através da comparação com os espécimes dos herbários visitados e da literatura especializada. 
Tabela 6 . Relação das espécies de jabuticabeiras identificadas, através da comparação de exsicatas presentes nos herbários visitados e na consulta de bibliografia especializada

\begin{tabular}{|c|c|}
\hline Código & Espécie \\
\hline Pira 1 & Psidium spp \\
\hline Pira 2 & Myrciaria jaboticaba(Vell.) Berg \\
\hline Pira 3 & Myrciaria cauliflora (DC.) Berg \\
\hline 11 & Myrciaria jaboticaba (Vell.) Berg \\
\hline 21 & Myrciaria cauliflora (DC.) Berg \\
\hline 31 & Myrciaria coronata Mattos \\
\hline 4I & Myrciaria coronata Mattos \\
\hline $5 \mathrm{I}$ & Myrciaria coronata Mattos \\
\hline 61 & Myrciaria cauliflora (DC.) Berg \\
\hline $7 \mathrm{I}$ & Myrciaria cauliflora (DC.) Berg \\
\hline 81 & Myrciaria cauliflora (DC.) Berg \\
\hline 91 & Myrciaria jaboticaba (Vell.) Berg \\
\hline 101 & Myrciaria jaboticaba (Vell.) Berg \\
\hline 111 & Myrciaria cauliflora (DC.) Berg \\
\hline 121 & Myrciaria cauliflora (DC.) Berg \\
\hline P01 & Myrciaria jaboticaba (Vell.) Berg \\
\hline P02 & Myrciaria jaboticaba(Vell.) Berg \\
\hline $\mathrm{P} 1 \mathrm{~A}$ & Myrciaria jaboticaba (Vell.) Berg \\
\hline P2A & Myrciaria jaboticaba(Vell.) Berg \\
\hline P3A & Myrciaria jaboticaba (Vell.) Berg \\
\hline P4A & Myrciaria jaboticaba (Vell.) Berg \\
\hline P5A & Myrciaria jaboticaba (Vell.) Berg \\
\hline P6A & Myrciaria jaboticaba (Vell.) Berg \\
\hline P7A & Myrciaria jaboticaba(Vell.) Berg \\
\hline P8A & Myrciaria jaboticaba (Vell.) Berg \\
\hline P9A & Myrciaria jaboticaba (Vell.) Berg \\
\hline P10A & Myrciaria jaboticaba (Vell.) Berg \\
\hline E01 & Myrciaria phitrantha Mattos \\
\hline E02 & Myrciaria cauliflora (DC.) Berg \\
\hline E03 & Myrciaria jaboticaba (Vell.) Berg \\
\hline E04 & Myrciaria jaboticaba (Vell.) Berg \\
\hline
\end{tabular}




\subsubsection{Identificação morfológica}

Os exemplares pertencentes a espécie Myrciaria jaboticaba (Vell.) O. Berg (Figura 22), apresentaram o ovário bicarpelar, ínfero, placentação axial, piloso sobre a base, estilete ultrapassando os estames, estigma captado, estames numerosos, ramos terminais achatados, folhas verdes na face superior e mais claras na inferior, corola pentâmera, actinomórfa e frutos globosos com diâmetro de 1,6 a 2,2 cm, negros quando maduros, lisos e de um a quatro sementes do seu interior. Características estas que estão de acordo com as descrições de Mattos (1983).

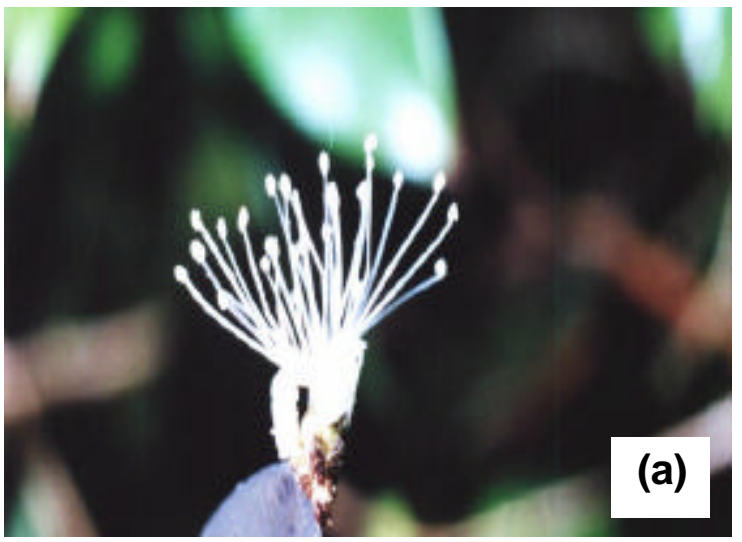

Figura 22 - Myrciaria jaboticaba - (a) detalhe da flor; (b) ramos com frutos maduros

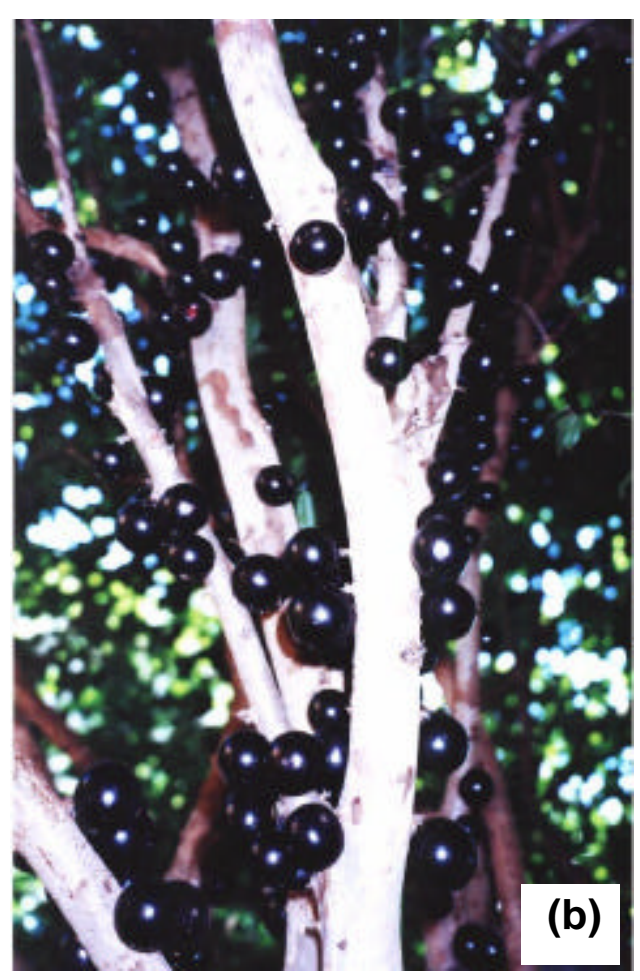


A espécie Myrciaria cauliflora (DC.) Berg (Figura 23), apresentou ovário bicarpelar, ínfero, placentação axial, glabro, estilete de $6 \mathrm{~mm}$ de comprimento, estigma peltado, ramos terminais achatados e folhas com nervura central levemente impressa na epiderme superior e saliente na inferior, corola pentâmera actinomórfa, botão floral glabro, fruto globoso, de 2,2 a 2,8 cm de comprimento e 2,2 a 2,9 cm de diâmetro.

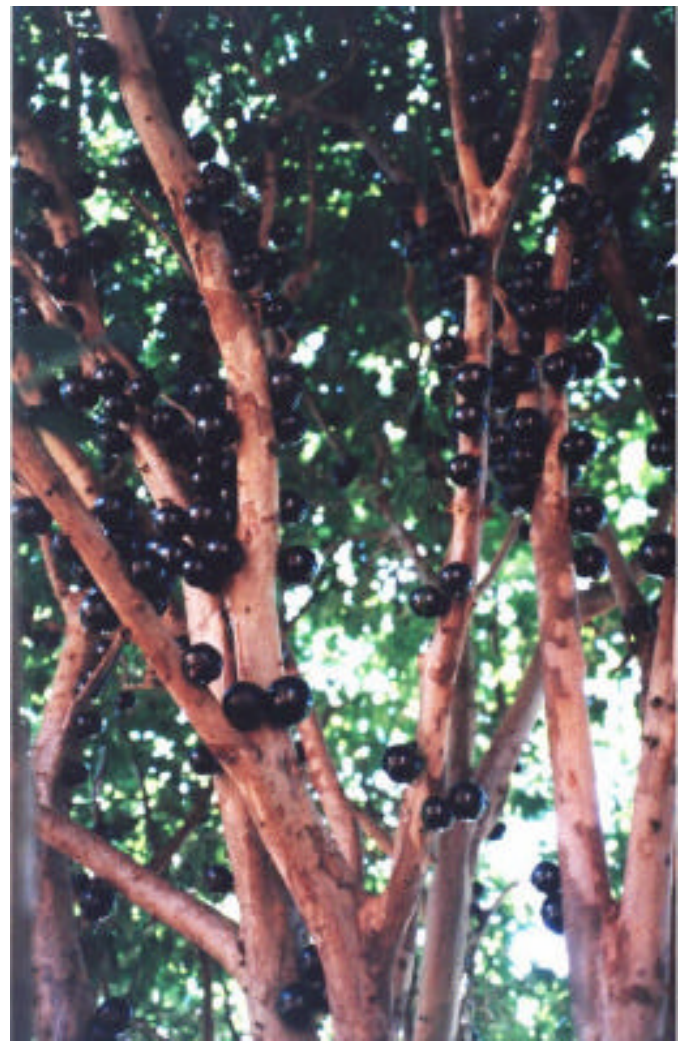

Figura 23 - Myrciaria cauliflora - Ramos com frutos maduros

A Myrciaria phitrantha (Kiaesk.) Mattos (Figura 24), apresenta ovário bicarpelar, ínfero, placentação axial, estile longo e glabro, corola pentâmera actinomórfa, fruto grande (de 3 a $4 \mathrm{~cm}$ de diâmetro) com o "pescoço" e como 
principal característica folhas grandes (mais do que o dobro das outras espécies estudadas ) e pendentes.

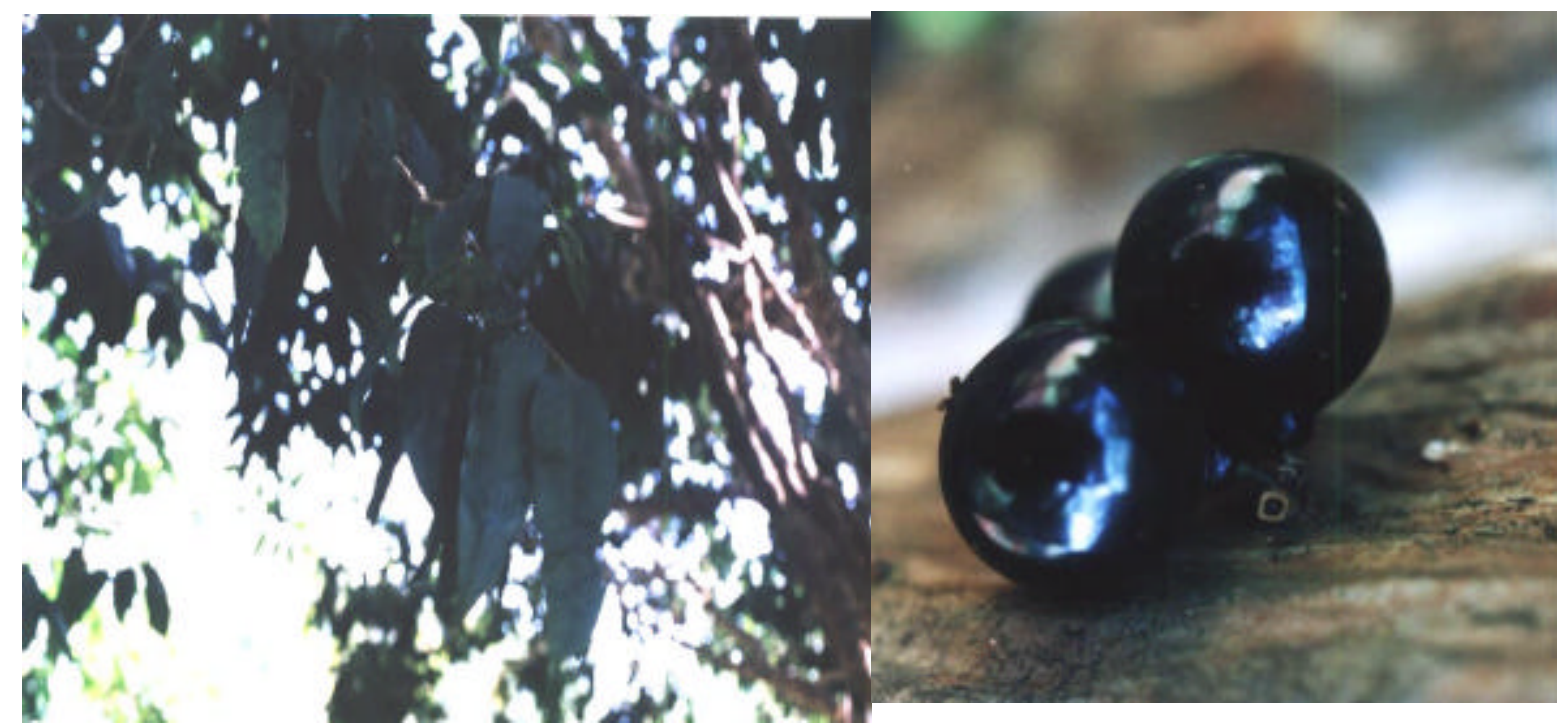

Figura 24 - Myrciaria phitrantha Mattos - Ramos terminais com folhas grandes e pendentes e detalhe dos frutos

Os exemplares da espécie Myrciaria coronata (Figura 25) apresentaram um estigma captado, ovário sericeo, bicarpelar com placentação axial ramos terminais achatados e cinzentos, folha com nervura principal impressa na face superior e saliente na inferior, fruto globoso e contorno do disco do ápice de cor esbranquiçada.

\subsubsection{Caracterização Anatômica}

Comparando-se os cortes transversais da região da casca e do lenho do caule jovem, pode-se observar que existem diferenças anatômicas entre as espécies de jabuticabeiras estudadas (Figuras 25, 26, 27 e 28). 
A região do suber da espécie Myrciaria phitrantha (Kiaersk) Mattos é a única a apresentar camadas pluriestratificadas, e uma periderme (pd) muito espessa, além de apresentar as fibras floemáticas (ff) em extratos descontínuos (Figura 25), as outras espécies, Myrciaria cauliflora (Mart.) O. Berg, Myrciaria jaboticaba (Vell.) O. Berg e Myrciaria coronata Mattos, apresentam fibras floemáticas contínuas e suber uniestratificado. Comparando-se a espécie Myrciaria jaboticaba (Figura 28), com as outras espécies (Figuras 25, 26 e 27), observa-se que as células do raio parenquimático (rp) são pouco organizadas nessa região. 


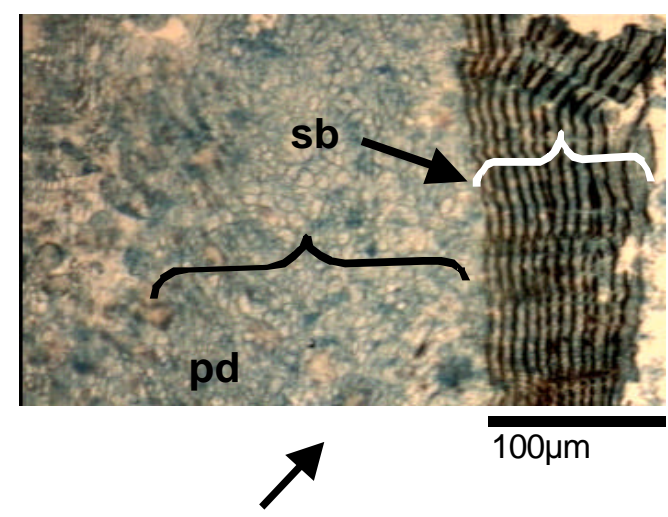

Figura 25 - Corte transversal da região de um ramo terminal de Myrciaria phitrantha, apresentando suber (sb) pluriestratificado com uma camada espessa de periderme (pd)

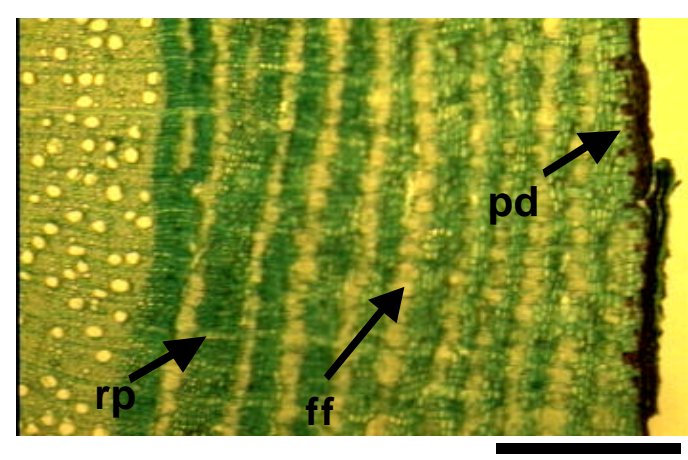

$100 \mu \mathrm{m}$

Figura 27 - Corte transversal do ramo terminal, região da casca, de Myrciaira cauliflora (DC.) Berg, mostrando fibras floemáticas (ff) formando extratos contínuos. Células do raio parenquimático (rp) atravessando a região do floema. Células de periderme (pd) formando uma camada pouca espessa e um suber uniestratificado

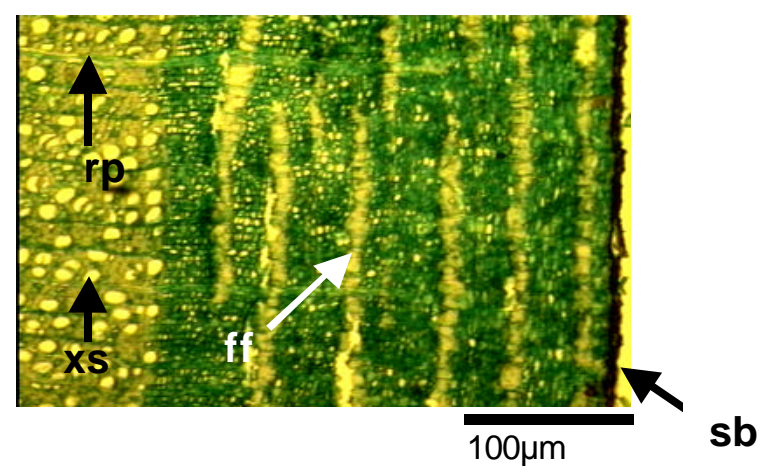

Figura 26 - Corte transversal da região da casca do caule de Myrciaria coronata Mattos mostrando a presença de fibras floemáticas (ff) formando extratos contínuos, suber uniestratificado (sb). Raio parenquimático (rp) com uma única camada de células e células de xilema secundário (xs) não alinhadas

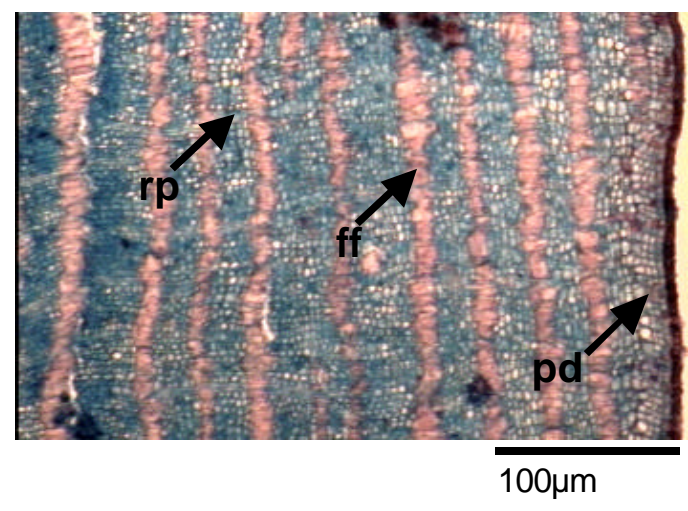

Figura 28 - Corte transversal do ramo terminal, região da casca, de Myrciaira jaboticaba (Vell.) Berg, mostrando fibras floemáticas (ff) formando extratos contínuos. Células de periderme (pd) formando uma camada pouca espessa e um suber uniestratificado.

Raios parenquimáticos (rp) pouco visíveis 
Quando se compara a região do lenho, através dos cortes transversais representados nas Figuras 29, 30, 31 e 32, observa-se que existem diferenças nessa região entre as espécies estudadas.

A espécie Myrciaria phytrantha (Kiaersk) Mattos (Figura 29), apresenta células do raio parenquimático (rp) uniestratificado, formado por uma única camada de células, além da presença de raios transversais também uniestratificados envolvendo, como um colar, os elementos de vaso de maior calibre do xilema secundário (xs). Essa é a única espécie que apresenta esta característica, ou seja, entre dois elementos de raio existe uma única camada de células de xilema secundário.

A região do lenho da Myrciaria cauliflora (Mart.) O. Berg (Figura 32) apresenta raios parenquimáticos ( $r p$ ) com duas camadas de células e entre um raio e outro várias camadas de células de elemento de vaso e traqueídes do xilema secundário (xs), sendo essa região a mais larga das espécies estudadas.

A espécie Myrciaria coronata Mattos (Figura 30) possui raios parenquimáticos (rp) com uma única camada de células, quando se compara com a mesma região da Myrciaria phitrantha (Kiaersk.) Mattos (Figura 29), são observadas de 2 a 3 células do xilema secundário (xs) dispostas de uma maneira perpendicular aos raios medulares.

As analises anatômicas corroboram as observações organográficas, na caracterização dessas espécies avaliadas de jabuticabeiras, facilitando dessa maneira a identificação taxonômica. 


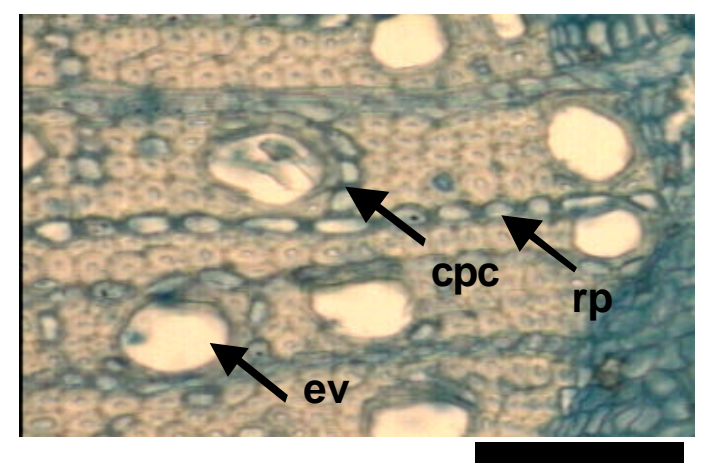

$50 \mu \mathrm{m}$

Figura 29 - Corte transversal do caule de Myrciaria phitrantha, região do lenho, mostrando células do raio parenquimático (rp) com uma única camada de células de elemento de vaso de maior diêmtro (ev) dispostas de uma maneira alinhada, sendo envolvidas por células parenquimáticas de comunicação entre os raios $(\mathrm{cpc})$

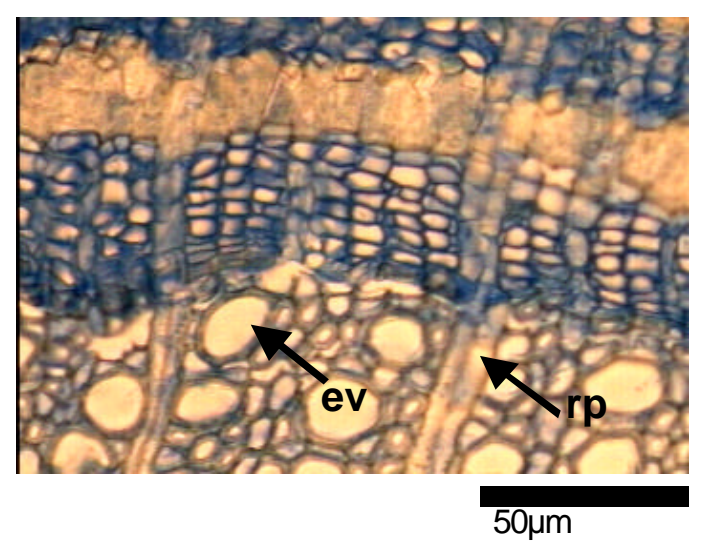

Figura 31 - Corte transversal do caule de Myrciaria jaboticaba (Vell.) Berg., região do lenho, mostrando raios parenquimáticos (rp) mais largos com células de elemento de vaso (ev) xilema dispostas de uma maneira não alinhada

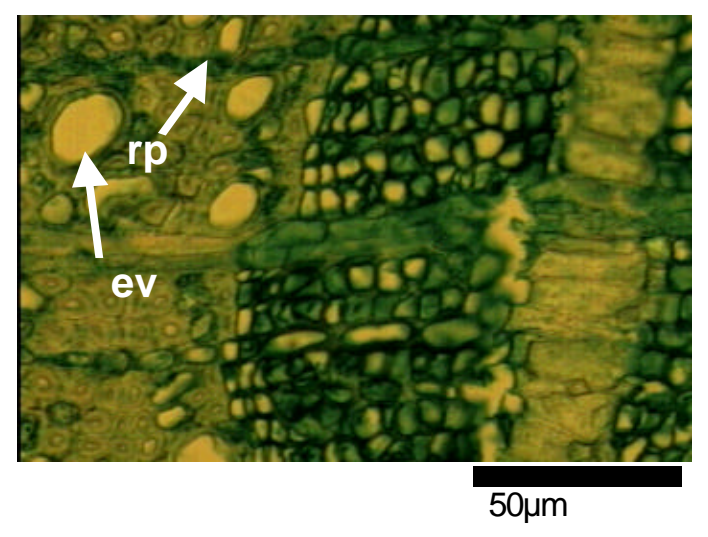

Figura 30 - Corte transversal do caule de Myrciaria coronata Mattos, mostrando a região do lenho com as células do raio parenquimático (rp) com uma única camada e células de xilema secundário (ev) dispostos de uma maneira não alinhada, e não envolvidas por células do raio

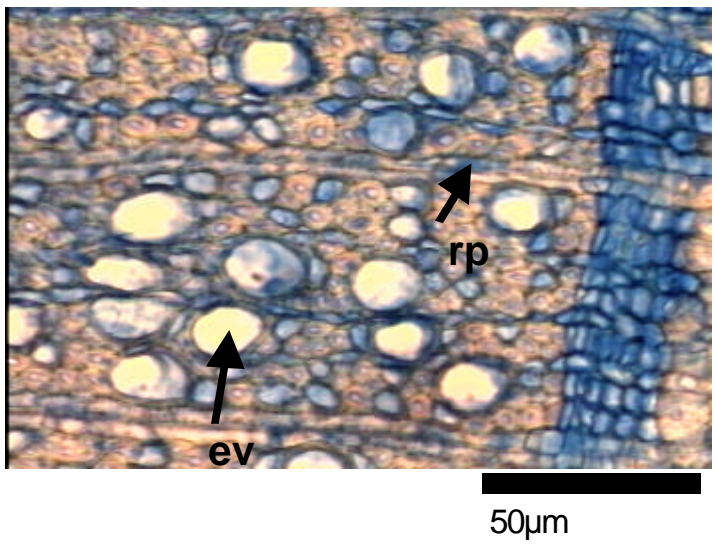

Figura 32 - Corte transversal do caule de Myrciaria cauliflora (DC.) Berg., região do lenho, mostrando as células do raio parenquimático (rp) com duas camadas e células do xilema secundário (ev) não alinhadas e não envolvidas por células do raio 


\subsubsection{Caracterização Molecular}

$\mathrm{Na}$ análise de marcadores RAPD, os 11 "primers" selecionados geraram 45 bandas polimórficas. Os "primers" mais polimórficos, foram os de número 203 e 226, sendo também os que apresentaram melhor imagem nos géis de agarose. Segundo Colombo et al. (1998), 10 a 30 "primers", gerando de 50 a 100 bandas polimórficas, são suficientes para estimar relações genéticas dentro e entre espécies. 


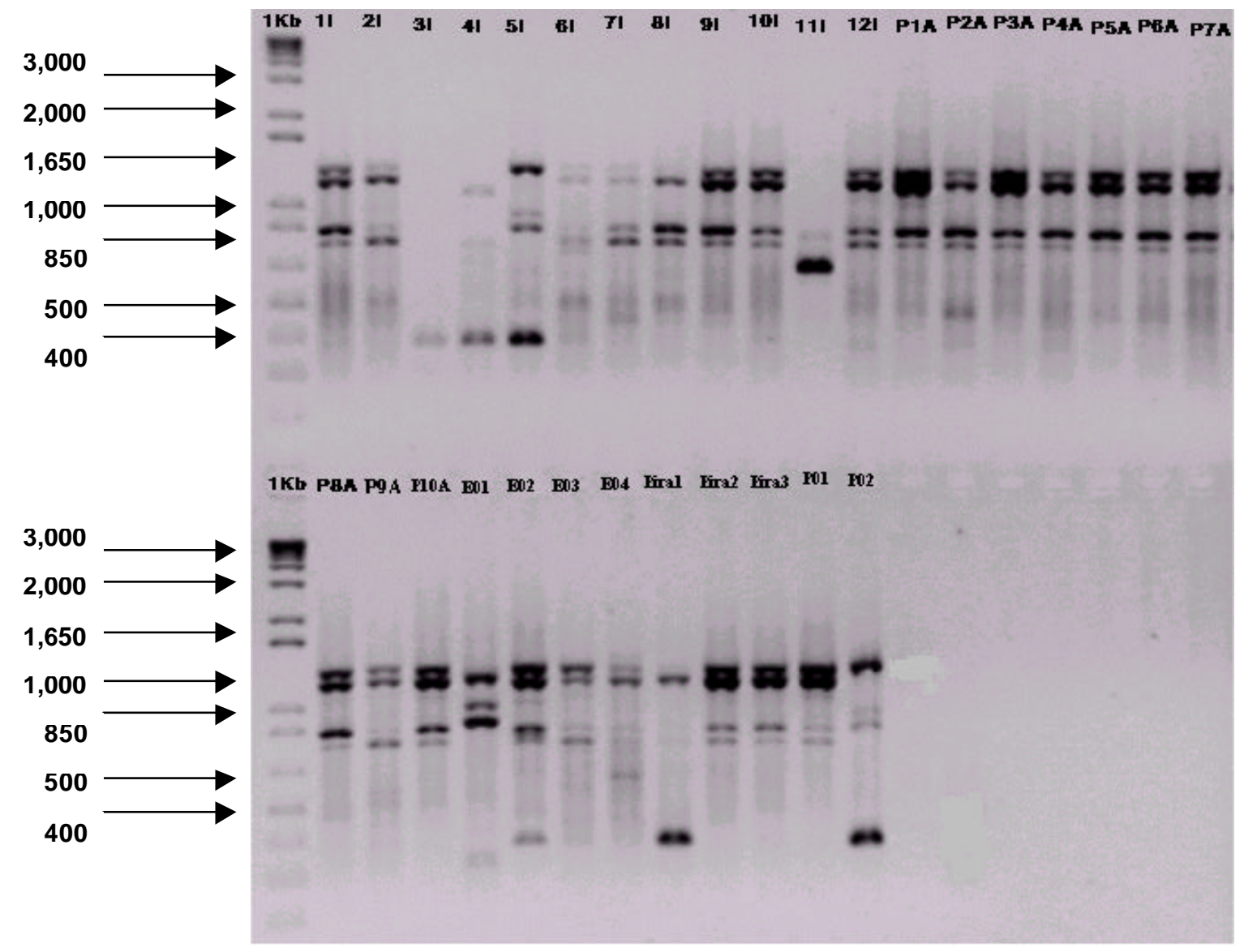

Figura 33 - Eletroforograma dos acessos amplificados com indicador de número 203, sendo: MM="1 Kb Plus DNA Ladder". 


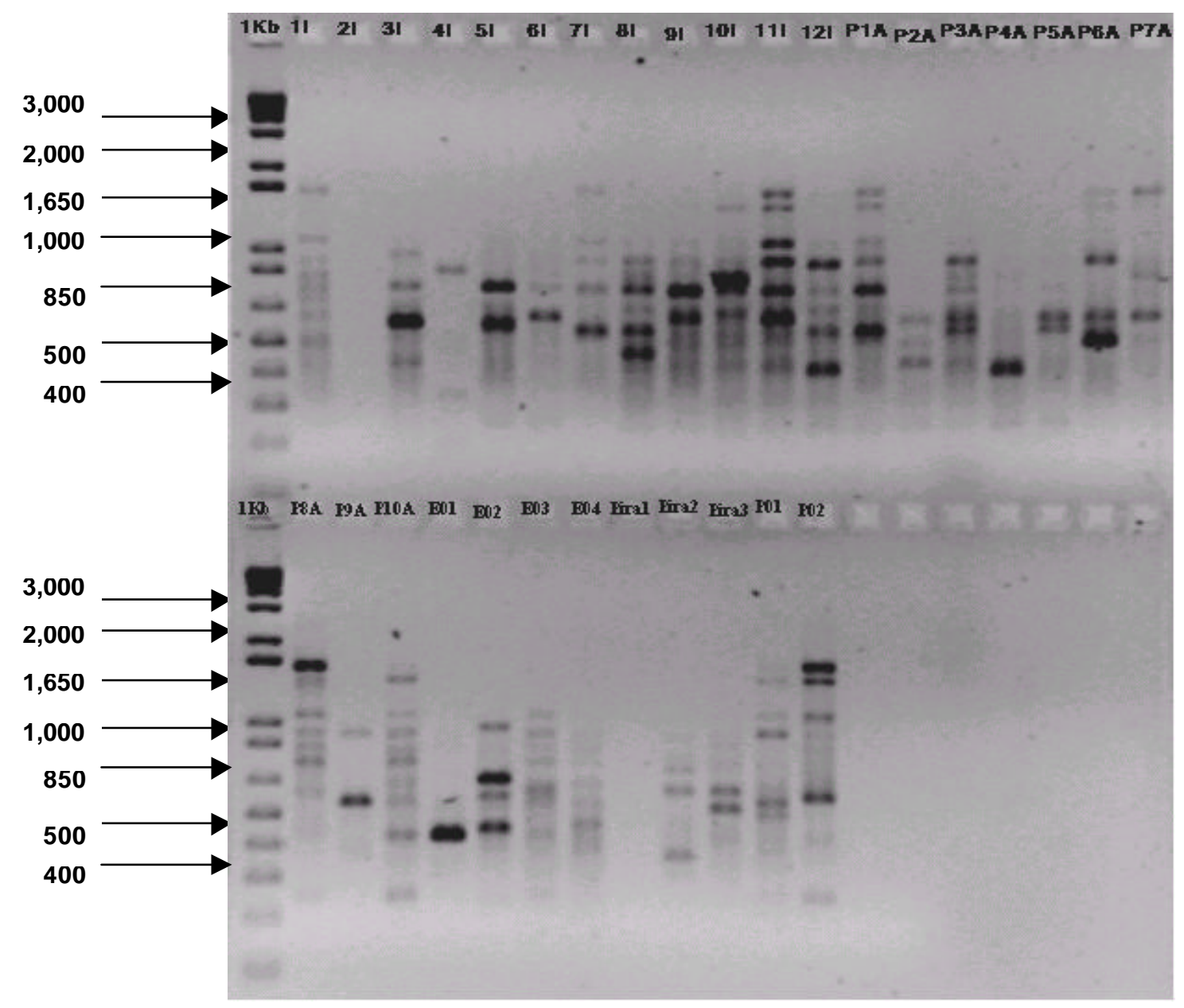

Figura 34 - Eletroforograma dos acessos amplificados com indicador de número 226, sendo: $\mathrm{MM}=" 1 \mathrm{~Kb}$ Plus DNA Ladder".

Ashburner et al. (1996) observaram que os marcadores do tipo "RAPD" foram capazes de diferenciar as populações de coco (Cocos nucifera L.) provenientes das llhas Rennel daquelas oriundas do continente. Esses fatos comprovam que a metodologia dos marcadores moleculares aplicada na identificação dos indivíduos pode ser uma ferramenta para auxiliar no agrupamento dos indivíduos pela sua similaridade genética. 


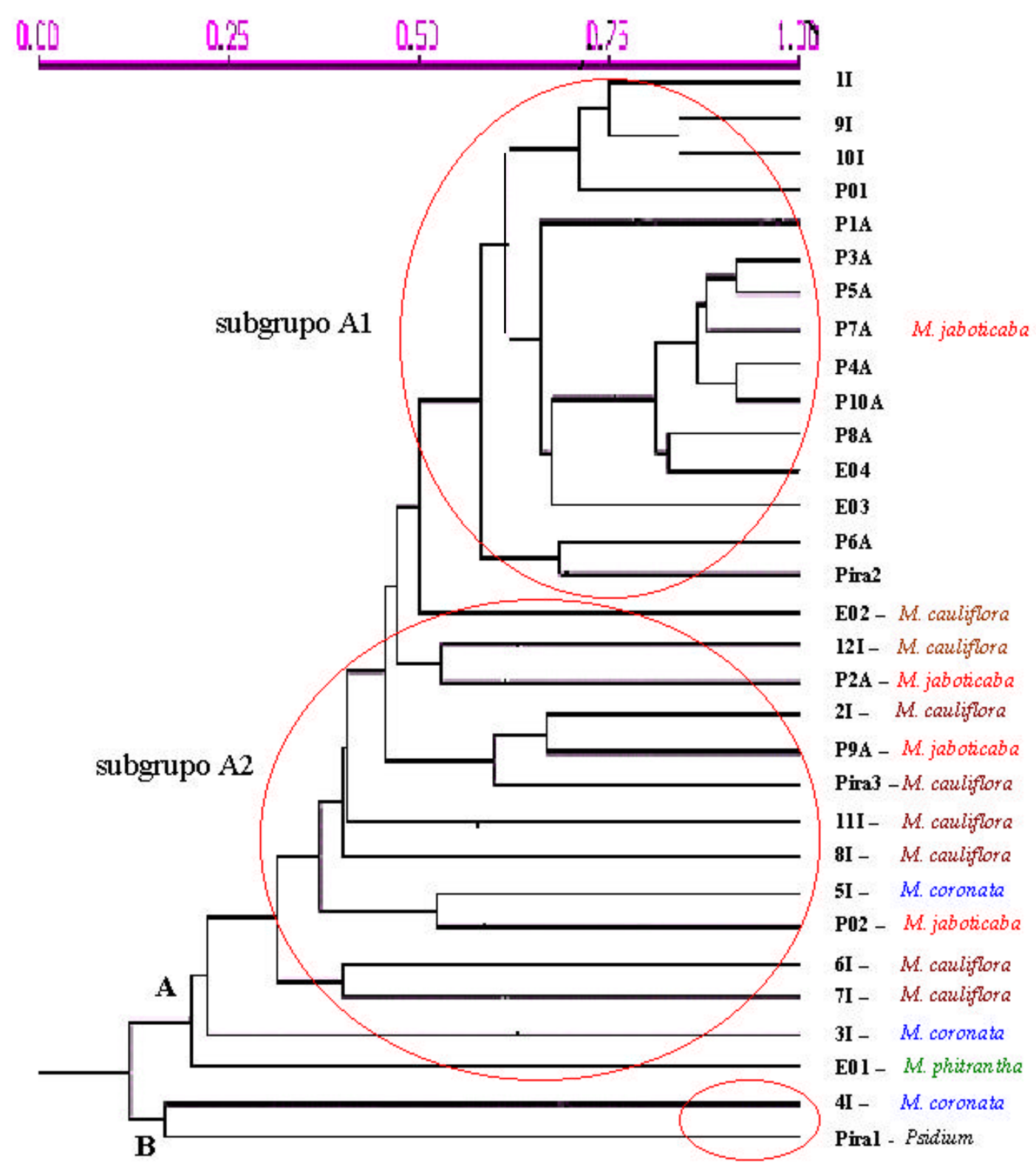

Figura 35 - Filograma de similaridade genética entre os indivíduos de jabuticabeiras, obtido pelo coeficiente de Jacard

$\mathrm{Na}$ figura 35, observa-se a formação de dois grupos principais: A e B. No grupo B, estão representadas apenas duas plantas, cuja distância genética é 
aproximadamente de 80\%. A planta de código "4l" está classificada morfologicamente, cuja espécie é Myrciaria coronata Mattos e a planta de código "Pira 1", após ter sido coletada como uma Myrciaria, foi identificada pertencente a família das Myrtáceas, mas do gênero Psidium spp.), confirmando, desta maneira, tal divergência entre elas.

No grupo A, encontram-se distribuídas outras espécies ( $M$. jaboticaba, M.cauliflora e M. phitrantha. Dentro desse mesmo grupo, observa-se a formação de um subgrupo (A1), onde encontram-se as plantas da espécie $M$. jaboticaba, com um grau de similaridade variando de $60 \%$ a $90 \%$.

Um outro subgrupo (A2), foi formado com espécies de $M$. cauliflora, $M$. coronata e M. jaboticaba, com graus de dissimilaridade de $80 \%$ a $30 \%$, no entanto, com características genéticas muito próximas.

A espécie $M$. phitrantha Mattos, apresenta uma divergência genética de $80 \%$ perante às demais espécies, que pode ser observada no Filograma em um ram o isolado dos demais grupos.

Neste contexto, conclui-se que a técnica RAPD-PCR, não permitiu 0 agrupamento das plantas ao nível de espécie, mas permitiu analisar, por meio do Filograma gerado, os graus de similaridade genética entre elas, observando que, a espécie $M$. phitrantha, distanciourse consideravelmente das outras espécies, assim como a planta identificada como Psidium spp., inicialmente coletada como Myrciaria, também teve alto grau de dissimilaridade, servindo para comprovar a confiabilidade desta técnica.

A princípio, observando-se o Filograma, infere-se que os marcadores RAPD, não permitiram o agrupamento das plantas, conforme mostra o subgrupo A2. No entanto, pelo estudo realizado, não há subsídios para afirmar tal fato, visto que, o material estudado, foi comparado com coleções mais antigas de Myrciarias, nas quais, ocorrem classificações divergentes, principalmente entre $M$. 
cauliflora e M. jaboticaba, comprovando-se a análise do subgrupo A2, na qual a maioria das plantas agrupadas pertencem a espécie $M$. cauliflora e, na qual estão presentes as plantas P2A, P9A e P02, classificados morfologicamente como $M$. jaboticaba.

Quanto à espécie $M$. coronata (3l, 4l e 5l), cuja classificação morfológica baseourse apenas na Literatura (MATTOS, 1983), sem que houvesse exsicatas desta espécie nos herbários visitados, sugere-se um levantamento mais minucioso, visto que, essas plantas, podem apresentar uma classificação divergente.

É evidente, no Filograma, que as maiores distâncias genéticas, envolvem as plantas do subgrupo A2, confirmando a dificuldade de uma classificação morfológica atual.

Atualmente, com o uso de ferramentas moleculares, poder-se-ia, sugerir uma revisão da classificação do gênero Myrciaria, assim como das exsicatas depositadas nos herbários visitados.

\subsection{Conclusões}

Através dos resultados obtidos com a realização deste trabalho, pode sugerir as seguintes conclusões:

Os trinta e um indivíduos identificados pertencem a quatro espécies: Myrciaria cauliflora (DC.) Berg, Myrciaria coronata Mattos, Myrciaria jaboticaba (Vell.) Berg, Myrciaria phitrantha (Kiaersk.) Mattos.

A espécie Myrciaria phitrantha (Kiaersk.) Mattos é a única das quatro espécies estudadas que apresenta a camada de suber pluriestratificada. 
A espécie Myrciaria jaboticaba (Vell.) O. Berg apresenta a região da casca mais espessa que a espécie Myrciaria cauliflora (Mart.) O. Berg.

O uso da técnica de marcadores moleculares (PCR) foi eficiente para analisar a distância genética das plantas estudadas.

\section{CONCLUSÕES GERAIS}

O enraizamento de estacas caulinares apicais de jabuticabeiras sofreu influência do tipo de substrato usado e dos valores de $\mathrm{pH}$ presentes nesse substrato, sendo que o substrato areia grossa e os $\mathrm{pHs}$ com valores 4.5 e 5.5 favoreceram a emissão de primórdios radiculares na base das estacas.

A utilização de reguladores vegetais (AIB), nas concentrações usadas, não influenciou a formação de raízes na base das estacas.

As jabuticabeiras identificadas neste trabalho pertencem as espécies, Myrciaria cauliflora (Mart.) O. Berg, Myrciaria coronata Mattos, Myrciaria jaboticaba (Vell.) O. Berg, Myrciaria phitrantha (Kiaersk.) Mattos. Sendo que existem diferenças anatômicas e moleculares entre elas.

Os marcadores moleculares (RAPD) foram capazes de estimar as relações genéticas existentes entre as espécies estudadas, sendo que podem ser usados com ferramentas para auxiliar na identificação de espécies de jabuticabeiras. 


\section{REFERÊNCIAS BIBLIOGRÁFICAS}

ANDERSEN, O.; ANDERSEN, V.U. As frutas silvestres brasileiras. 3ed. Rio de Janeiro: Globo, 1988, p.131-135.

ASHBURNER, G. R.; THOMPSON, W.K.; HALLORAN, G.M. RAPD analysis of south pacific coconut palm populations. Crop Science, v.37, p.992-997, 1996.

AVANZATO, D.; CHERUBIN, S. Influence of the substrates on the direct rooting of ex vitro, MM106 apple microcuttings. Acta Horticulturae, n.342, p.296302, 1993.

BLAZICK, F. A.; HEUSER, C.W. A histological study of adventitious root initiation in mung bean cuttings. Journal of the American Society of Horticultural Science. , v. 104, p.63-67, 1979.

COLOMBO, C. et al. Genetic diversity characterization of casava cultivars (Manihot esculenta Crantz) with RAPD markers. Genetics and Molecular Biology, Ribeirão Preto, v.21, n.1, p.105-113, 1998

COSTA, Júnior W. H. Enraizamento de estacas de goiabeiras: influência de fatores fisiológicos e mesológicos. Piracicaba, 2000, 66p. Dissertação (Mestrado) - Escola Superior de Agricultura "Luiz de Queiroz", Universidade de São Paulo. 
DONADIO, L.C. Jaboticaba (Myrciaria jaboticaba (Vell.) Berg). Jaboticabal: FUNEP, 2000, 55p.

DUARTE, O.; LUDDERS, P.; HUETE, M. Propagation of Jaboticaba by terminal leafy cuttings. Acta Horticulturae, Wageningen, n.452, p.123-128, 1997./Apresentado ao International Symposium on Myrtaceae/ Acta Horticulturae, n.452, p.123-128, 1997-Proceedings/

EL-TOMI, A.L. GALAL, M.A. Origin and development of adventitious roots in semi-hardwood cuttings of sweet lemon. Egyptian Journal of Horticulture, v.7, n.1, p.79-80, 1980.

ERICKSEN, E.N.; MOHAMMED, S. Root formation in pea cuttings. II. The influence of indole-3-acetic acid at different developmental stages. Physiologia Plantarum, v.30, p.158-162, 1974.

ESAU, K. Plant anatomy. 2.ed. New York: J. Wiley, 1965. p.69.

EVANS, H. R. Recent work on the propagation of coffee from cuttings in Kenya. Tropical Agriculture Surrey, v. 35, p.67-76, 1958.

FAHN, A. Anatomia vegetal. 3.ed. Madrid: Piramide, 1982, 599p.

FERREIRA, M.E., GRATTAPAGLIA, D. Introdução ao uso de marcadores em análise genética. 2.ed. Brasília: EMBRAPA-CENARGEM, 1996. p.220 (Documento, 20)

HAISSIG, B.E. Meristematic activity during adventitious root primordium development. I. Influences of endogenous auxin and applied gibberellic acid. Plant Physiology, v.49, p.886-892, 1972.

HARBAGE, J.F.; STIMART, D.P. Effect of $\mathrm{pH}$ and $1 \mathrm{H}$-indole-3-butyric acid (IBA) on rooting of apple microcuttings. Journal of the American Society for Horticultural Science, v.121, n.6, p.1049-1053, 1966. 
HARTMANN, H.T.; KESTER, D.E.; DAVIES, F.T. Plant propagation: principles and pratices. New Jersey: Prentice Hall, 1990, 647p.

HAYWARD, H. E. The structure of economic plants. New York: Mac Millan, 1938, 58p.

HEUTHER, W.; BATCHELOR, L.D.; WEBBER, H.J. The citrus industry. 2.ed. California: University of California, 1973. v.3, p.32-37.

HOOKEY, J.V.; EDWARDS, V.; Patelatel, S.; Richardson JF, Cookson et al. Use of fluorescent amplified fragment length polymorphism (FAFLP) to characterize methicillin-resistant Staphylococcus aureus. Journal Microbiology Methods, v.37, p. 7-15, 1999

JABUTICABA. Guia Rural, v.4, n.1, 1990, p.26.

JOHNSON, C.R.; HAMILTON, D.F. Effects of media and controlled-release fertilizers on rooting and leaf nutrient composition of Junipers conferta and ligustrum japonicum cuttings. Journal of the American Society for Horticultural Science, v.102, n.3, p.320-322, 1977.

KANESIRO, M.A.B. Efeito da irradiação gema e embalagens na conservação pós-colheita de jabuticabas (Myrciaria sp). Ituverava, SP-Faculdade de Agronomia Dr. Francisco Maeda. . 2002, 136p. Trabalho (Graduação).

LEE, T.T.; STARRATT, A.N. ; JEVNIKAR, J.J. Regulation of enzymic oxidation of indole-3-acetic acid by phenols: structure - activity relationships. Phytochemic News., v.21, p.517-523, 1982.

$\mathrm{LOACH}, \mathrm{K}$. Hormone applications and adventitious root formation in cuttings - a critical review. Acta Horticulturae., v.227, p.126-133, 1988. 
LODHI, M.A. ; YE, N.G.; , WEEDEN, N.F. et al. A simple and efficient method for DNA extraction from grapevine cultivars and Vitis species. Plant Molecular Biology Reporter v. 12: p6-13, 1994.

MANICA, I. Frutas nativas, exóticas e silvestres. Porto Alegre: Cinco Continentes. Editora, 2000. 327p.

MATTOS, J.L.R. Fruteiras nativas do Brasil: jaboticabeiras. Porto Alegre: Nobel, 1983. 92p.

MENDONÇA, R.M.N. Maturação, secagem e armazenamento de sementes e propagação vegetativa de Jabuticabeiras (Myrciaria sp). Viçosa, 2000. 136p. Tese (Doutorado). Universidade Federal de Viçosa.

MESSINA, R.; TESTOLINI, R. Indagini anatomiche sull'origine delle radici avventizie in talee di Actinidia (Actinidia chinensis Planch). Riveste Ortoflorofruticolture, v.68, p.51-56, 1984.

MIDDLETON, W., JARVIS, B.C., BOOTH, A. The role of leaves in auxin and boron-dependent rooting of stem cuttings of Phaseolus aureus Roxb. New Phytology, v.84, p.251-259, 1980.

MULLIS, K. ; FALOONA, F. Specific syntheses of DNA in vitro via a polymerase catalysed chain reaction. Methods Enzymol, v.55, p335-350. 1994.

MUÑOZ, H.I; VALENZUELA, B.J. The rooting capacity of softwood cuttings from three varieties of grapevine. The effect of the position on the shoot and the time of collection. Agricultura Tecnica, v.38, p.14-17, 1978.

OLIVEIRA, L. A. Caracterização morfológica e molecular da jabuticabeira (Myrciaria sp). Ituverava: FAFRAM, 2002, 190p. (Relatório Científico FAPESP). 
ONO, E. O.; RODRIGUES, J. D.; PINHO, S.Z. Estudo da influência da época de coleta dos ramos, no enraizamento de estacas caulinares de café (Coffea arábica L. cv 'Mundo Novo'). Crop Science, v.49, n.1, p.29-35, 1992.

PIO CORRÊA, M. Dicionário das plantas úteis do Brasil e das exóticas cultivadas. Rio de Janeiro: IBDF, 1984. v.4. 450p.

PREECE, J.E.; READ, P.E. The Biology of Horticulture. New York: John Wiley, 1993. 480p.

PRIESTLEY, J. H.; SWINGLE, C.F. Vegetative propagation from the stand point of plant anatomy. Unites States of American - Department of Agriculture Technical Bulletin, v.151, p.1-99, 1929.

RODRIGUES, J.D.; ONO, E.O. Aspectos da fisiologia do enraizamento de estacas caulinares. Jaboticabal: FUNEP, 1996. 83p.

ROHLF, F.J., SLICE, D.E NTSYS-Numeral taxonomy and multivariate analysis system. New York: Exater Software, 1992115 p.

RUGGIERO, C. Maracujá. Ribeirão Preto: Legis Summa, 1987. 246p.

SÃO PAULO. SECRETARIA DE AGRICULTURA E ABASTECIMENTO. COORDENADORIA DE ABASTECIMENTO. Perfil dos hortigranjeiros comercializados no ETSP: Frutas. São Paulo, 19909, p.73-77.

SCARPARE FILHO, J.A.; ANTONIOLLI, LR; CASTRO, PRC; et al. Efeito do ácido indolbutírico no enraizamento de estacas herbáceas de jabuticabeira 'Sabará' (Myrciaria jabuticaba) em condições de nebulização. Revista Brasileira de Fruticultura, v.21, n.2, p.146-149, ago. 1999. 
SCARPARE, F.V.; KLUGE, R.A.; SCARPARE FILHO, J.A.; BORBA, M.R.C. Propagação da jabuticabeira 'Sabará' (Myrciaria jaboticaba (Vell.) Berg.) através de estacas caulinares. Congresso Brasileiro de Fruticultura, 17, 2002.

SÉRIE DOCUMENTOS. Técnicas de coleta, preservação e herborização de material botânico. Instituto de Botânica. São Paulo, 1989. 62p.

SILVA, I. C. Propagação vegetativa; Aspectos Morfológicos. Itabuna: CEPLAC, 1985. v.4, p.1-26 (Boletim Técnico).

STIMART, D.P.; HARBAGE, J.F. Growth of rooted 'Gala' apple microcuttings as influenced by initial adventittious root count. HorstScience, v.26, n.6, p.664666, 1993.

SUNNUCKS P. Efficient genetic markers for population biology. TREE, v 15, n.5, 2000, p.199-203.

TAIZ, L.; ZEIGER, E. Plant physiology. Massachesetts: Sunderland, 1998. $799 p$.

THOMPSON, W.K. Effects os origin, time of collection, auxins and planting media on rooting of Epacris impressa. Scientia Horticulturae, v.30, n.1/2, p.127-134, 1986.

VAN OVERBEEK, J.; GORDON, S.A; GREGORY, L.E. An analysis of the function of the leaf in th e process of root formation in cuttings. American Journal of Botany, v. 33, p.100-107, 1946.

VILANOVA, M.T. Propagación vegetativa del café. Café Salvado, v.29, p.669$681,1959$. 
WELSH, J. ; MCCLELLAND, M. Fingerprinting genomes using PCR with arbitary primers. Nucleic Acids Research, v.18, p.7213-7218, 1990.

WENT, F.W. Synergistic factors other than auxin affecting growth and root formation. Plant Physiology, v.13, p.55-80, 1938.

WHITE, J., LOVELL, P.H. The anatomy of root initiation in cuttings of Griselinia littoralis and G. Lucida. Annals of Botany., v.54, p.7-20, 1984.

WILLIAMS, R.R.; TAJI, A.M.; BOLTON, J.A. Suberization and adventitious rooting in Australian plants. Australian Journal of Botany, v.32, p.363-366, 1984.

WILLIAMS, J.G.K., KUBELIK, A.R.; LIVAK, K.J J.A. et al. DNA polymorfims amplified by arbitrary primers useful as genetic markers. Nucleic Acids Research, v.18, p.6531-6535, 1990.

WILLIAMS, J.G.K.; RAFALSKI, J.A. ; TINGEY, S.V. Genetic analyss using RAPD markers. Methods in Enzymology, v.218, p.704-740, 1993. 